UNIVERSIDADE DE BRASÍLIA

FACULDADE DE AGRONOMIA E MEDICINA VETERINÁRIA

PROGRAMA DE PÓS-GRADUAÇÃO EM AGRONOMIA

DESEMPENHO AGRONÔMICO, PARÂMETROS GENÉTICOS E REAÇÃO DE CLONES DE BATATA-DOCE AOS INSETOS DE SOLO E AOS NEMATOIDES DAS GALHAS (Meloidogyne spp.)

DAIANE DA SILVA NÓBREGA

DISSERTAÇÃO DE MESTRADO EM AGRONOMIA

BRASÍLIA/DF

JULHO/2015 


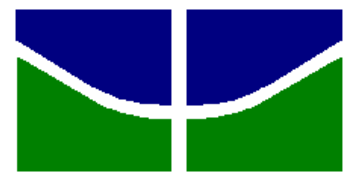

UNIVERSIDADE DE BRASÍLIA

FACULDADE DE AGRONOMIA E MEDICINA VETERINÁRIA

PROGRAMA DE PÓS-GRADUAÇÃO EM AGRONOMIA

DESEMPENHO AGRONÔMICO, PARÂMETROS GENÉTICOS E REAÇÃO DE CLONES DE BATATA-DOCE AOS INSETOS DE SOLO E AOS NEMATOIDES DAS GALHAS (Meloidogyne spp.)

DAIANE DA SILVA NÓBREGA

ORIENTADOR: Dr. JOSÉ RICARDO PEIXOTO

DISSERTAÇÃO DE MESTRADO EM AGRONOMIA

PUBLICAÇÃO n ${ }^{\circ} 96$

BRASÍLIA/DF

JULHO/2015 

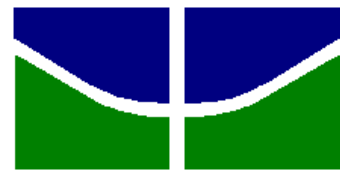

UNIVERSIDADE DE BRASÍLIA

FACULDADE DE AGRONOMIA E MEDICINA VETERINÁRIA

PROGRAMA DE PÓS-GRADUAÇÃO EM AGRONOMIA

\title{
DESEMPENHO AGRONÔMICO, PARÂMETROS GENÉTICOS E REAÇÃO DE CLONES DE BATATA-DOCE AOS INSETOS DE SOLO E AOS NEMATOIDES DAS GALHAS (Meloidogyne spp.)
}

\author{
DAIANE DA SILVA NÓBREGA
}

DISSERTAÇÃO DE MESTRADO SUBMETIDO À FACULDADE DE AGRONOMIA E MEDICINA VETERINÁRIA DA UNIVERSIDADE DE BRASÍLIA, COMO PARTE DOS REQUISITOS NECESSÁRIOS À OBTENÇÃO DO GRAU DE MESTRE EM AGRONOMIA.

APROVADO POR:

JOSÉ RICARDO PEIXOTO, Dr. ${ }^{\circ}$

Faculdade de Agronomia e Medicina Veterinária - Universidade de Brasília - UnB (ORIENTADOR), e-mail: peixoto@unb.br

MICHELLE SOUZA VILELA, Dr. ${ }^{\text {a }}$

Faculdade de Agronomia e Medicina Veterinária - Universidade de Brasília - UnB (EXAMINADOR INTERNO), e-mail: michellevilelaunb@gmail.com

JADIR BORGES PINHEIRO, Dr. $^{\circ}$

Pesquisador da Embrapa Hortaliças (CNPH)

(EXAMINADOR EXTERNO), e-mail: jadir.pinheiro@embrapa.br

BRASÍLIA/DF, 09 DE JULHO DE 2015 


\section{FICHA CATALOGRÁFICA}

Nóbrega, Daiane da Silva

DESEMPENHO AGRONÔMICO, PARÂMETROS GENÉTICOS E REAÇÃO DE CLONES DE BATATA-DOCE AOS INSETOS DE SOLO E AOS NEMATOIDES DAS GALHAS (Meloidogyne spp.).

Orientação: José Ricardo Peixoto - Brasília, 2015.

129 p.: il.

Dissertação de Mestrado (M) - Universidade de Brasília/Faculdade de Agronomia e Medicina Veterinária, 2015.

1. Batata-doce. 2. Insetos de solo. 3. Nematoides das galhas. 4. Meloidogyne spp. 5. Qualidade de raiz.

\section{REFERÊNCIA BIBLIOGRÁFICA}

NÓBREGA, D. S. Desempenho agronômico, parâmetros genéticos e reação de clones de batata-doce aos insetos de solo e aos nematoides das galhas (Meloidogyne spp.). Brasília: Faculdade de Agronomia e Medicina Veterinária, Universidade de Brasília, 2015, 129 p.: il. Dissertação de Mestrado.

\section{CESSÃO DE DIREITOS}

NOME DO AUTOR: Daiane da Silva Nóbrega

TÍTULO DA DISSERTAÇÃO: Desempenho agronômico, parâmetros genéticos e reação de clones de batata-doce aos insetos de solo e aos nematoides das galhas (Meloidogyne spp.).

GRAU: Mestre

ANO: 2015

É concedida à Universidade de Brasília de Brasília permissão para reproduzir cópias desta dissertação de mestrado para única e exclusivamente propósitos acadêmicos e científicos. O autor reserva para si os outros direitos autorais, de publicação. Nenhuma parte desta dissertação de mestrado pode ser reproduzida sem a autorização por escrito do autor. Citações são estimuladas, desde que citada à fonte.

Daiane da Silva Nóbrega

E-mail: daiane_nobrega@hotmail.com 


\section{AGRADECIMENTOS}

Agradeço a Deus por me conceder o "Dom da vida", sem o qual não seria possível vivenciar mais essa conquista!

Aos meus pais pelo exemplo de vida e por acreditar que a educação é a maior herança a ser deixada aos filhos. Pela confiança, amor, cuidado e sabedoria dedicada a mim.

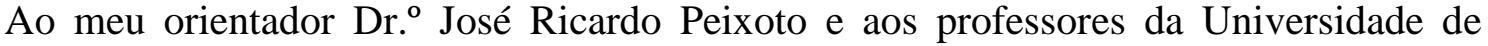
Brasília (UnB) Dr..$^{\circ} J e a n$ Kleber Mattos, Dr. ${ }^{a}$ Michelle Souza Vilela e Dr. ${ }^{\circ}$ Márcio de Carvalho Pires pelos ensinamentos, confiança, apoio e incentivo.

Ao Dr. Jadir Borges Pinheiro, pesquisador da Embrapa Hortaliças (CNPH), por aceitar participar da banca examinadora, pela disponibilidade e ensinamentos.

A todos os funcionários da Fazenda Água Limpa e da Estação Experimental de Biologia da Universidade de Brasília, aos técnicos do Laboratório de Alimentos da UnB e também aos alunos/estagiários que de alguma forma contribuíram para realização deste trabalho.

Aos meus amigos que sempre me apoiaram, alegraram e encorajaram nos momentos de dificuldade, agradeço pelo companheirismo e amizade. Em especial a Elaine Caetano pela ajuda nas avaliações em laboratório e a Ane Kelly Nóbrega nas avaliações em campo, sem as quais seria impossível finalizar esse trabalho.

Aos meus amigos Poliana Schrammel, Elaine Caetano, Camila Eufrasio, Letícia Alvarenga, Rosângela Pereira e Kleiton Aquiles pela amizade sincera, pois mesmo distantes estão sempre presentes me acompanhando e aconselhando na minha trajetória acadêmica, tornando os meus dias mais divertidos e agradáveis.

As minhas amadas primas, companheiras de baladas, por aguentar minhas inúmeras reclamações, chatices, "descabelamentos" e ausências na família. Agradeço pela amizade, torcida, alegria e pelos animados momentos de descontração que passamos juntas.

Muito obrigada! 


\section{SUMÁRIO}

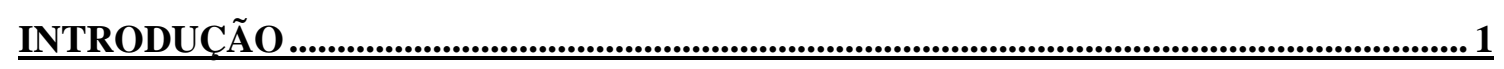

REVISÃO BIBLIOGRÁFICA

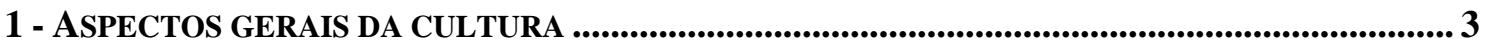

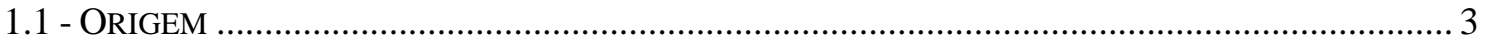

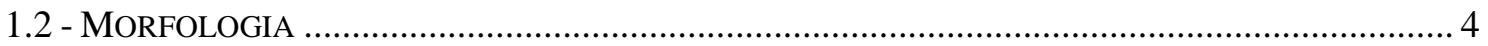

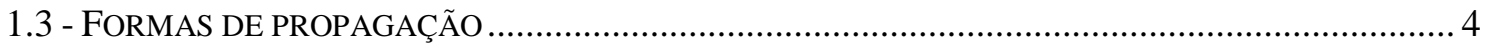

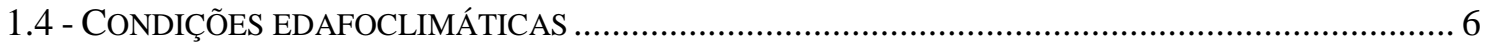

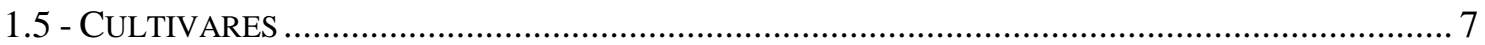

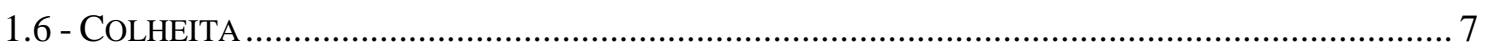

2 - ASPECTOS SOCIOECONÔMICOS........................................................................................................... 8

3 - INFORMAÇÕES NUTRICIONAIS ........................................................................................................ 9

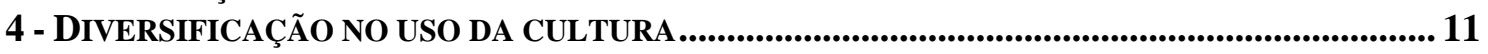

5 - NEMATOIDES E INSETOS DE SOLO QUE ATACAM A BATATA-DOCE ......................................... 13

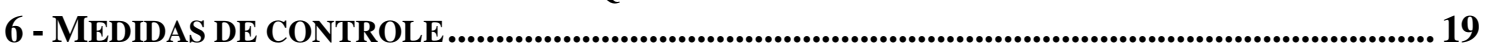

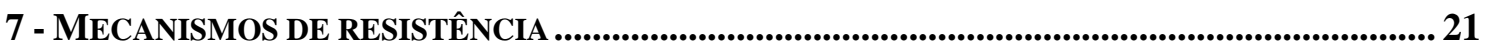

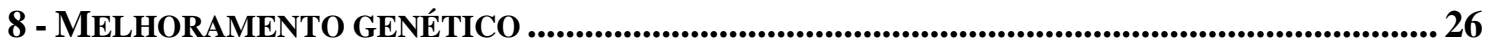

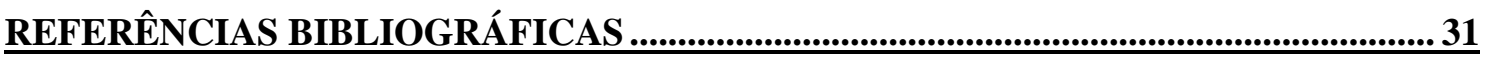

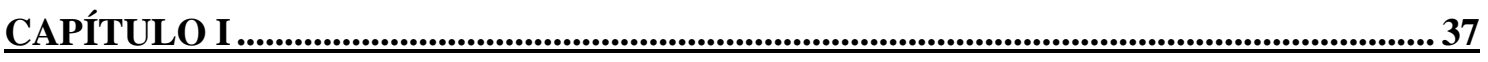

PRODUTIVIDADE E RESISTENCIA DE CLONES DE BATATA-DOCE AOS

INSETOS DE SOLO_............................................................................................................ 37

INTRODUCẼ̃

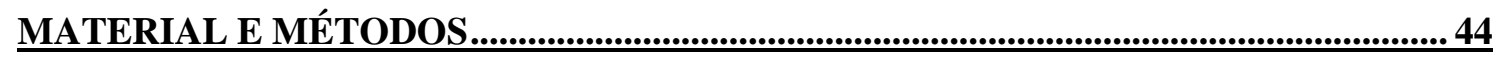

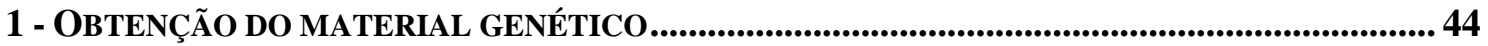

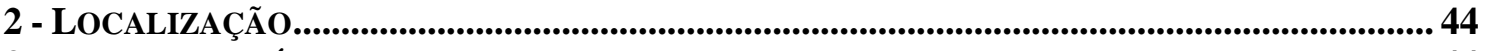

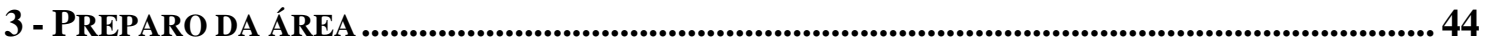

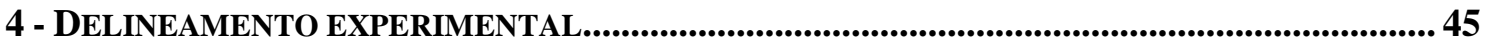

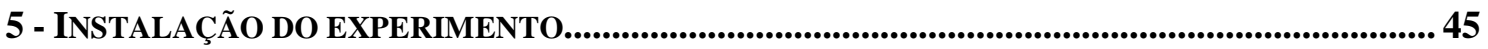

6 - CONDUÇÃO DO EXPERIMENTO ........................................................................................................ 46

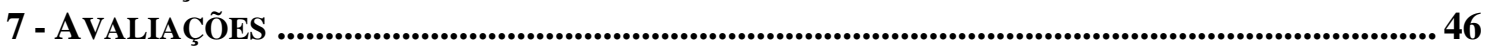

7.1 - NÚMERO DE FUROS POR RAIZ, INCIDÊNCIA DE DANOS E GRAU DE RESISTÊNCIA ................. 47

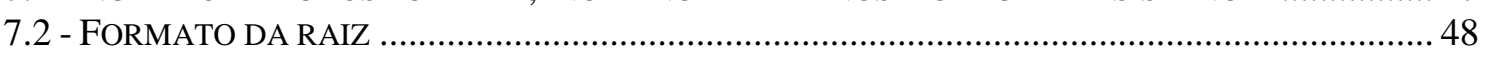

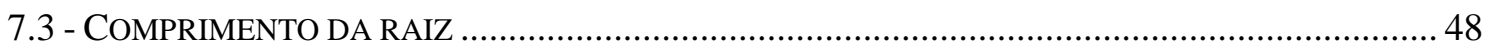

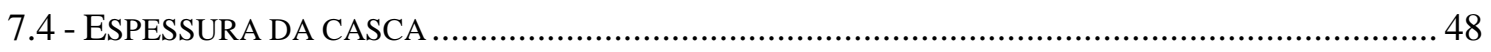

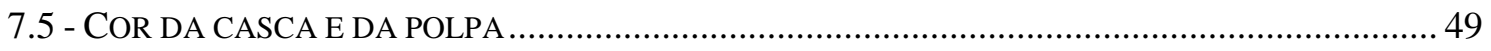

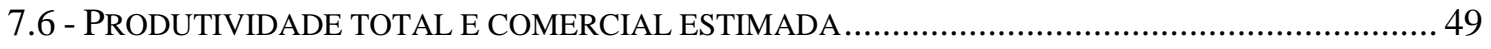

7.7 - PERCENTUAL DE SÓLIDOS SOLÚVEIS TOTAIS (SST) .......................................................... 49

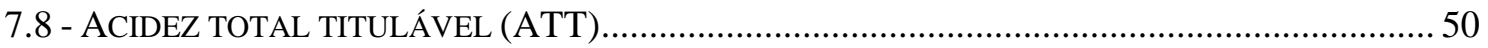

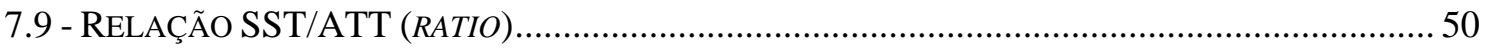

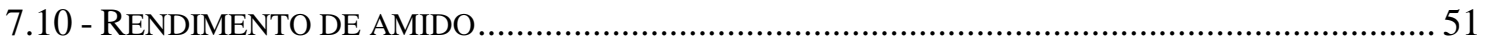

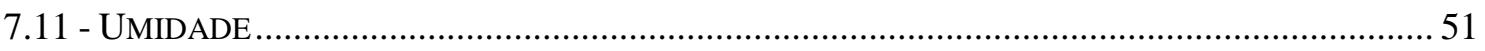




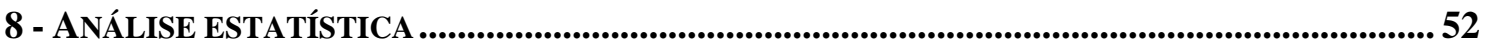

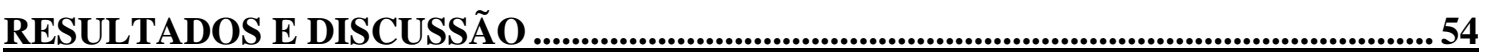

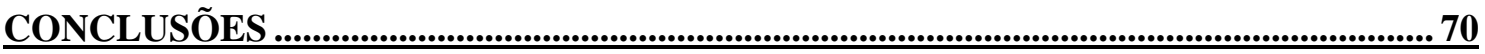

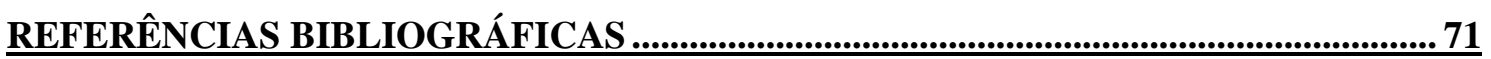

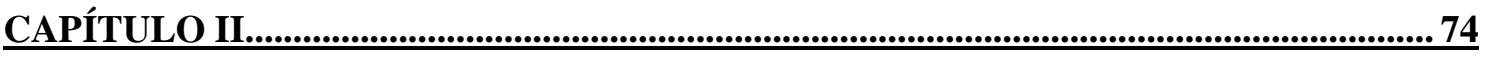

RESISTÊNCIA DE CLONES DE BATATA-DOCE AOS NEMATOIDES DAS GALHAS

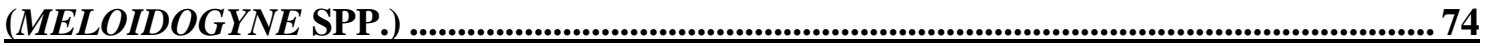

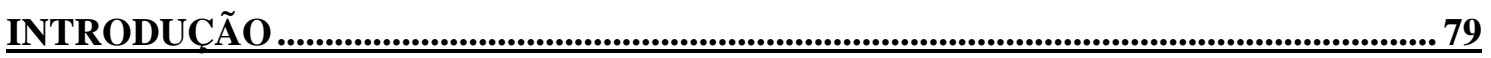

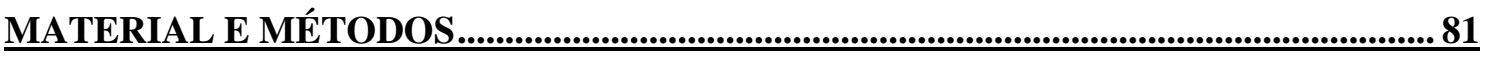

1 - OBTENÇÃO DO MATERIAL GENÉTICO..................................................................................... 81

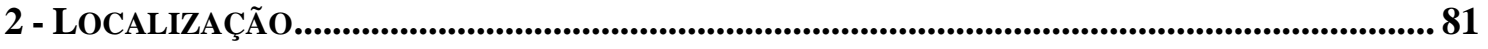

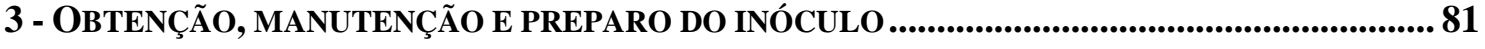

4 - DELINEAMENTO EXPERIMENTAL................................................................................................. 83

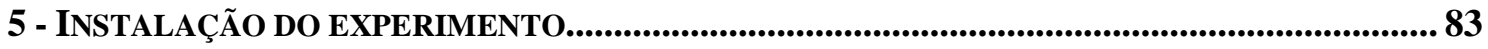

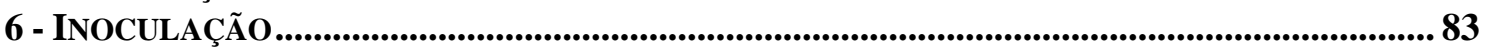

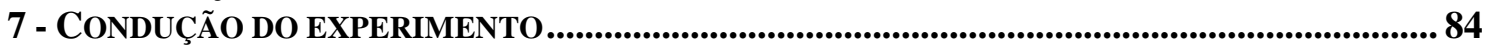

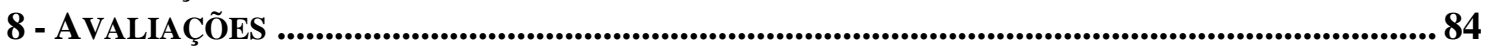

A) PESO DA MASSA FRESCA (MFPA) E MASSA SECA DA PARTE AÉREA (MSPA) ….................... 84

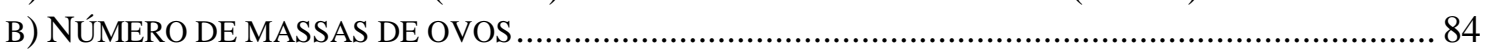

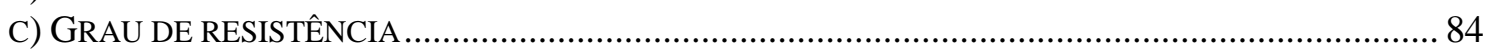

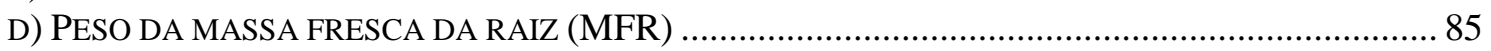

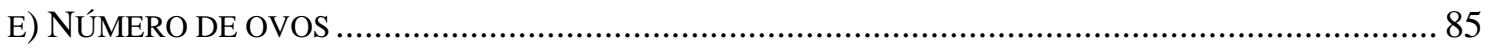

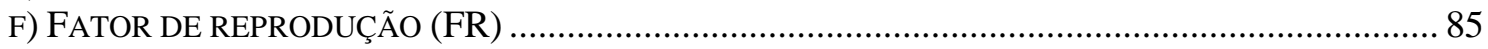

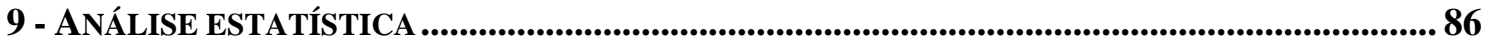

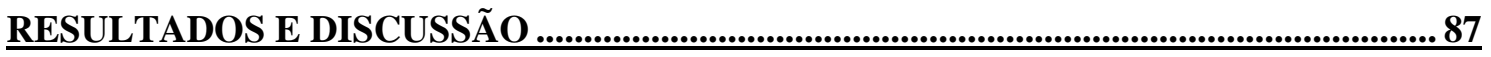

1 - REAÇÃO DE GENÓTIPOS DE BATATA-DOCE À INFECÇÃO POR MELOIDOGYNE INCOGNITA 87

2 - REAÇÃO DE GENÓTIPOS DE BATATA-DOCE À INFECÇÃO POR MELOIDOGYNE PARANAENSIS

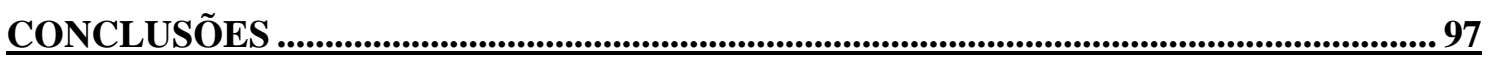

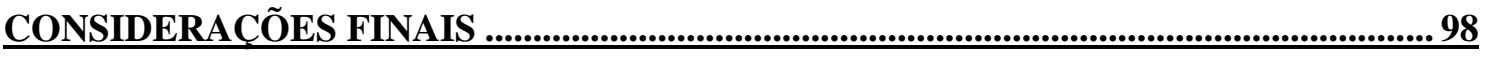

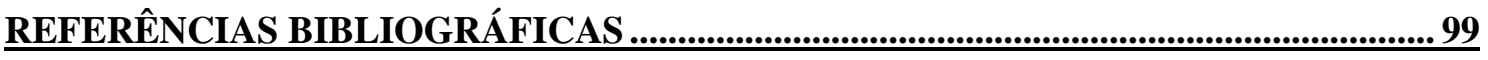

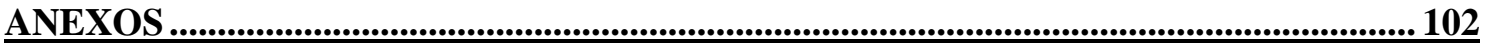




\section{LISTA DE FIGURAS}

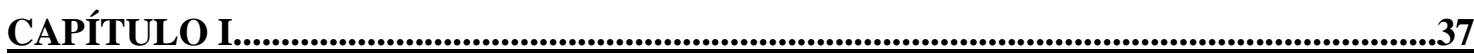

PRODUTIVIDADE E RESISTÊNCIA DE CLONES DE BATATA-DOCE AOS

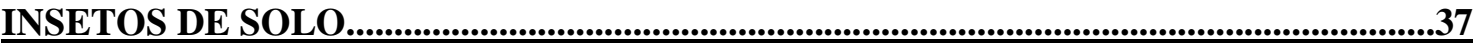

FIGURA 1 - PREPARO DA ÁREA DE PLANTIO PARA INSTALAÇÃO DO EXPERIMENTO, LOCALIZADA NA FAZENDA ÁGUA LIMPA (FAL), PERTENCENTE À UNIVERSIDADE DE BRASÍLIA. UNB, BRASÍLIA, 2015 .45

FIGURA 2 - PREPARO DOS CAMALHÕES DE PLANTIO PARA INSTALAÇÃO DO EXPERIMENTO NA FAL, PERTENCENTE À UNIVERSIDADE DE BRASÍLIA. UNB, BRASÍLIA, 2015.

FIGURA 3 - ÁREA DE PLANTIO COM DIVISÃO DE PARCELAS PARA INSTALAÇÃO DO EXPERIMENTO NA FAL, PERTENCENTE À UNIVERSIDADE DE BRASÍLIA. UNB, BRASÍLIA, 2015 . .46

FIGURA 4 - ESTACAS DOS GENÓTIPOS DE BATATA-DOCE PRÉ-ENRAIZADAS EM BANDEJAS DE POLIESTIRENO, UTILIZADAS PARA PLANTIO DO EXPERIMENTO NA FAL, PERTENCENTE À UNIVERSIDADE DE BRASÍLIA. UNB, BRASÍLIA, 2015 .46

FIGURA 5 - ESTACAS DOS GENÓTIPOS DE BATATA-DOCE PRÉ-ENRAIZADAS EM BANDEJAS DE POLIESTIRENO, UTILIZADAS PARA PLANTIO DO EXPERIMENTO NA FAL, PERTENCENTE À UNIVERSIDADE DE BRASÍlIA. UNB, BRASÍlLIA, 2015.

FIGURA 6 - ESCALA DE NOTAS UTILIZADA PARA A AVALIAÇÃO DA COR DA CASCA.

FIGURA 7 - ESCALA DE NOTAS UTILIZADA PARA A AVALIAÇÃO DA COR DA POLPA

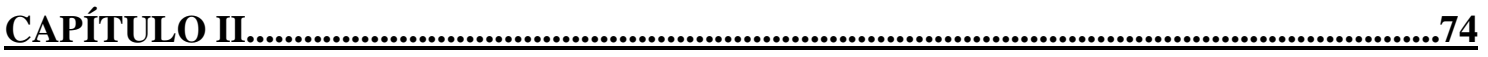

RESISTENNCIA DE CLONES DE BATATA-DOCE AOS NEMATOIDES DAS GALHAS

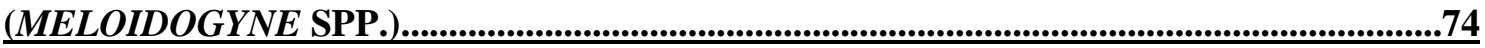

FIGURA 1 - MULTIPLICAÇÃO DA ESPÉCIE DE NEMATOIDE M. INCOGNITA EM MUDAS DE TOMATEIRO, EM CASA DE VEGETAÇÃO, NA ESTAÇÃO EXPERIMENTAL DA UNIVERSIDADE DE BRASÍLIA. UNB, BRASÍLIA, 2015 . 


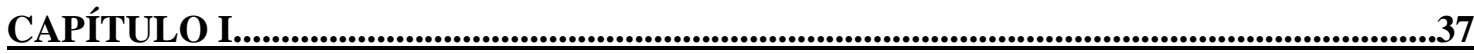

PRODUTIVIDADE E RESISTÊNCIA DE CLONES DE BATATA-DOCE AOS

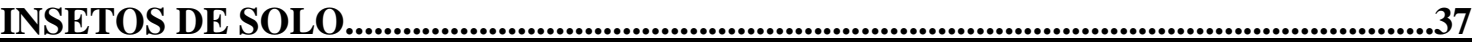

TABELA 1 - GENÓTIPOS DO BANCO DE GERMOPLASMA (BAG) DE BATATA-DOCE DA EMBRAPA HORTALIÇAS. FAV/UNB, 2015. .44

TABELA 2 - CLASSIFICAÇÃO DA RESISTÊNCIA COM BASE NA INCIDÊNCIA DE DANOS MÉDIA DA PARCELA. FAV/UNB, 2015.

TABELA 3 - MÉDIAS DAS VARIÁVEIS PRODUTIVIDADE TOTAL E COMERCIAL ESTIMADA DE RAÍZES DOS GENÓTIPOS DE BATATA-DOCE AVALIADOS. FAV/UNB, 2015.

TABELA 4 - MÉDIAS DAS VARIÁVEIS NÚMERO DE FUROS E INCIDÊNCIA DE DANOS CAUSADOS POR INSETOS DE SOLO E GRAU DE RESISTÊNCIA DOS GENÓTIPOS DE BATATA-DOCE AVALIADOS. FAV/UNB, 2015. . .56

TABELA 5 - MÉDIAS DAS VARIÁVEIS COMPRIMENTO, ESPESSURA DA CASCA E FORMATO DAS RAÍZES DOS GENÓTIPOS DE BATATA-DOCE AVALIADOS. FAV/UNB, 2015.

TABELA 6 - IDENTIFICAÇÃO DAS CORES DE CASCA E POLPA DAS RAÍZES DOS GENÓTIPOS DE BATATA-DOCE AVALIADOS. FAV/UNB, 2015.

TABELA 7 - MÉDIAS DOS TEORES DE SÓLIDOS SOLÚVEIS TOTAIS, ACIDEZ TOTAL TITULÁVEL, RATIO, RENDIMENTO DE AMIDO E UMIDADE DAS RAÍZES DOS GENÓTIPOS AVALIADOS. FAV/UNB, 2015.

TABELA 8 - ESTIMATIVAS DA HERDABILIDADE NO SENTIDO AMPLO $\left(\mathrm{H}_{\mathrm{A}}{ }^{2}\right)$, COEFICIENTE DE VARIAÇÃO GENÉTICO $\left(\mathrm{CV}_{\mathrm{G}}\right)$ E RAZÃO ENTRE COEFICIENTE DE VARIAÇÃO GENÉTICO E AMBIENTAL $\left(\mathrm{CV}_{\mathrm{G}} / \mathrm{CV}_{\mathrm{E}}\right)$ DE 13 VARIÁVEIS AVALIADAS PARA 10 GENÓTIPOS DE BATATA-DOCE EM CAMPO NO DISTRITO FEDERAL. FAV/UNB, 2015.

RESISTÊNCIA DE CLONES DE BATATA-DOCE AOS NEMATOIDES DAS GALHAS

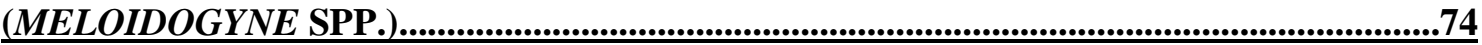

TABELA 1 - GENÓTIPOS DO BANCO DE GERMOPLASMA (BAG) DE BATATA-DOCE DA EMBRAPA HORTALIÇAS. FAV/UNB, 2015 .81

TABELA 2 - CLASSIFICAÇÃO DA RESISTÊNCIA DE ACORDO COM O NÚMERO MÉDIO DE MASSAS DE OVOS PRESENTES EM CADA SISTEMA RADICULAR. FAV/UNB, 2015.

TABELA 3 - MÉDIAS DAS VARIÁVEIS MASSA FRESCA DA PARTE AÉREA POR PLANTA (MFPA/PL), MASSA SECA DA PARTE AÉREA POR PLANTA (MSPA/PL), MASSA FRESCA DA RAIZ POR PLANTA (MFR/PL), NÚMERO DE OVOS POR 
PARCELA ( $\mathrm{N}^{\circ}$ OVOS/PA), NÚMERO DE OVOS POR PLANTA (OVOS/PL) E NÚMERO DE OVOS POR GRAMA DE RAIZ (OVOS/GRAIZ) DOS TRATAMENTOS AVALIADOS QUANTO A RESISTÊNCIA A MELOIDOGYNE INCOGNITA. FAV/UNB, 2015

TABELA 4 - MÉDIAS DO FATOR DE REPRODUÇÃO (FR), GRAU DE RESISTÊNCIA SEGUNDO O FATOR DE REPRODUÇÃO (GRFR), NÚMERO DE MASSA DE OVOS POR PLANTA ( $\mathrm{N}^{\circ} \mathrm{MO} / \mathrm{PL}$ ) E GRAU DE RESISTÊNCIA SEGUNDO O NÚMERO DE MASSAS DE OVOS (GRMO) DOS TRATAMENTOS AVALIADOS QUANTO À RESISTÊNCIA A MELOIDOGYNE INCOGNITA. FAV/UNB, 2015 .90

TABELA 5 - MÉDIAS DAS VARIÁVEIS MASSA FRESCA DA PARTE AÉREA POR PLANTA (MFPA/PL), MASSA SECA DA PARTE AÉREA POR PLANTA (MSPA/PL), MASSA FRESCA DA RAIZ POR PLANTA (MFR/PL), NÚMERO DE OVOS POR PARCELA ( $\mathrm{N}^{\circ}$ OVOS/PA), NÚMERO DE OVOS POR PLANTA ( ${ }^{\circ}$ OVOS/PL) E NÚMERO DE OVOS POR GRAMA DE RAIZ (OVOS/GRAIZ) DOS TRATAMENTOS AVALIADOS QUANTO A RESISTÊNCIA A MELOIDOGYNE PARANAENSIS. FAV/UNB, 2015 . .92

TABELA 6 - MÉDIAS DO FATOR DE REPRODUÇÃO (FR), GRAU DE RESISTÊNCIA SEGUNDO O FATOR DE REPRODUÇÃO (GRFR), NÚMERO DE MASSA DE OVOS POR PLANTA ( $\mathrm{N}^{\circ} \mathrm{MO} / \mathrm{PL}$ ) E GRAU DE RESISTÊNCIA SEGUNDO O NÚMERO DE MASSAS DE OVOS (GRMO) DOS TRATAMENTOS AVALIADOS QUANTO À RESISTÊNCIA A MELOIDOGYNE PARANAENSIS. FAV/UNB, 2015. .94 


\begin{abstract}
ANEXOS
ANEXO A - TABELAS DE ANÁLISES DE VARIÂNCIA E PARÂMETROS GENÉTICOS.

ANEXO B - CROQUI DO EXPERIMENTO.

ANEXO C - FOTOS DOS EXPERIMENTOS INOCULADOS EM CASA DE VEGETAÇÃO......




\section{DESEMPENHO AGRONÔMICO, PARÂMETROS GENÉTICOS E REAÇÃO DE CLONES DE BATATA-DOCE AOS INSETOS DE SOLO E AOS NEMATOIDES DAS GALHAS (Meloidogyne spp.)}

\section{RESUMO GERAL}

A utilização de germoplasma de batata-doce resistente tem permitindo aos programas de melhoramento genético obter novas variedades mais produtivas e resistentes a doenças e pragas, constituindo-se numa importante alternativa de controle. Este trabalho teve como objetivo avaliar o desempenho agronômico de genótipos de batata-doce em campo e casa de vegetação. O trabalho consistiu na avaliação de dois ensaios, sendo o primeiro quanto ao desempenho agronômico e o segundo quanto à resistência da batata-doce aos nematoides das galhas Meloidogyne incognita e Meloidogyne paranaensis. Os genótipos avaliados em ambos os ensaios foram oriundos do Banco de Germoplasma da Embrapa Hortaliças (CNPH). O primeiro ensaio foi conduzido na Fazenda Água Limpa da Universidade de Brasília (UnB) e o segundo ensaio na Estação Experimental de Biologia da UnB. O primeiro ensaio foi instalado utilizando-se o delineamento experimental de blocos casualizados com 10 tratamentos, 4 repetições e 10 plantas de batata-doce/parcela. Foram avaliados 10 genótipos: Princesa (CNPH 3), Brazlândia Rosada (CNPH 9), Santa Sofia (CNPH 17), CNPH 29, Georgia Inproved (CNPH 31), Balão (CNPH 46), CNPH 53, Batata Africana 1 (CNPH 61), Batata Correntina ${ }^{\circ} 24$ (CNPH 66) e CNPH 71. As características avaliadas foram: número de furos; incidência de danos; grau de resistência; formato e comprimento de raiz; espessura e cor da casca; cor da polpa; produtividade total e comercial; percentual de sólidos solúveis totais (SST); acidez total titulável (ATT); ratio (relação SST/ATT); umidade e rendimento de amido. O genótipo CNPH 53 apresentou a maior produtividade total estimada com 26,78 t/ha e o genótipo Brazlândia Rosada se destacou para a produtividade comercial estimada demonstrando 13,75 t/ha. O genótipo CNPH 71 obteve o melhor desempenho com o menor número de furos $(9,09)$ e incidência de danos $(2,44)$, tendo grau de resistência moderadamente suscetível. Também os genótipos Georgia Improved, Balão, CNPH 53, Batata Africana 1 e Batata Correntina ${ }^{\circ}$ 24 se classificaram como moderadamente suscetíveis. O genótipo CNPH $29(158,89$ $\mathrm{mm}$ ) apresentou melhor resultado para o comprimento das raízes. Os genótipos Brazlândia Rosada e Batata africana 1 demonstraram a maior espessura da casca com $0,11 \mathrm{~cm}$. Os genótipos Georgia Improved $(1,87)$ e Santa Sofia $(1,92)$ demonstraram os 
melhores formatos. Dos dez genótipos estudados apenas o CNPH 71 possui cor da casca creme escuro e somente o CNPH 53 possui casca roxa, quanto ao restante $30 \%$ possui cor da casca creme e $50 \%$ cor da casca rosado. Em relação à cor da polpa, $80 \%$ apresentaram a polpa creme e $20 \%$ creme escuro. O genótipo CNPH $53(12,25)$ demonstrou o melhor resultado para o teor de SST. Com relação à acidez foram superiores: Santa Sofia (2,37\%), CNPH 29 (2,53\%), CNPH 53 (2,76 \%) e CNPH 71 $(3,10)$. A razão ratio desse estudo demonstrou os melhores resultados para os tratamentos CNPH 53 (4,42), Santa Sofia $(4,25)$, CNPH $29(4,24)$ e CNPH $71(4,17)$, sendo os genótipos mais precoces dentre os estudados. Apenas os genótipos Princesa $(70,18)$ e CNPH $29(70,91)$ obtiveram teor de umidade próximo de $70 \%$. Os genótipos CNPH 53 (11,98\%), Princesa (11,38 \%), CNPH 29 (10,39\%) e Georgia Improved $(9,78 \%)$ se destacaram como os mais promissores obtendo os maiores teores de amido. A produtividade comercial estimada, umidade e amido demonstraram valores de herdabilidade acima de $90 \%$ e valores superiores a 1 para a razão $\mathrm{CVg} / \mathrm{CVe}$, com indicação de pequeno efeito ambiental e seleção efetiva para estas características, mesmo utilizando métodos simples de melhoramento genético. No segundo ensaio foi utilizado delineamento experimental de blocos casualizados em arranjo simples, com 10 tratamentos, 3 repetições, 5 plantas de batata-doce/parcela para a espécie Meloidogyne incognita e 3 plantas de batata-doce/parcela para a espécie Meloidogyne paranaensis. Foram avaliados 10 genótipos: Princesa (CNPH 3), Roxinha (CNPH 5), Brazlândia Rosada (CNPH 9), Georgia Improved (CNPH 31), Balão (CNPH 46), CNPH 53, Batata Africana 1 (CNPH 61), Batata Correntina $n^{\circ} 24$ (CNPH 66), CNPH 80, Palmeira (CNPH 1796). As características analisadas foram: peso da massa fresca da parte aérea, peso da massa seca da parte aérea, peso da massa fresca das raízes, número de ovos por parcela, número de ovos por planta, número de ovos por grama de raiz, número de massas de ovos, fator de reprodução e grau de resistência. No ensaio com Meloidogyne incognita o genótipo CNPH 53 foi o mais promissor em relação à massa fresca da parte aérea $(14,33 \mathrm{~g})$, o genótipo Georgia Improved se destacou para a massa seca da parte aérea $(4,33 \mathrm{~g})$ e o genótipo Brazlândia Rosada para a massa fresca de raiz $(12,64 \mathrm{~g})$. Todos os genótipos estudados apresentaram-se resistentes com base na análise do fator de reprodução, porém em relação ao número de massas de ovos esses mesmos genótipos se mostraram todos suscetíveis. No ensaio com Meloidogyne paranaensis o genótipo CNPH 53 se mostrou mais vigoroso tanto com relação à massa fresca da parte aérea $(26,39 \mathrm{~g})$, quanto para a massa seca da parte aérea $(5,83 \mathrm{~g})$, enquanto que os 
genótipos Brazlândia Rosada (16,11 g) e Batata Correntina $\mathrm{n}^{\circ} 24(15,00$ g) se destacaram para a massa fresca de raiz. O genótipo CNPH 80 apresentou resistência com base no número de massas de ovos, sendo os demais genótipos suscetíveis. Os genótipos CNPH 80, Georgia Improved, Balão, Princesa e CNPH 53 demonstraram-se resistentes segundo o fator de reprodução, enquanto os demais genótipos foram suscetíveis. O genótipo CNPH 80 foi o único que demonstrou resistência ao $M$. paranaensis tanto em relação ao fator de resistência, quanto ao número de massas de ovos.

Palavras-chave: doença, estacas, Ipomoea, nematoide das galhas, resistência, insetos de solo, produtividade, qualidade de raiz. 


\section{AGRICULTURE PERFORMANCE, GENETIC PARAMETERS AND REACTION OF CLONES OF SWEET POTATO TO SOIL INSECTS AND TO ROOT-KNOT NEMATODES (Meloidogyne spp.)}

\section{OVERVIEW}

The utilization of germplasm resistant of sweet potato has allowing breeding programs to obtain new varieties more productive and resistant to pests and diseases, constituting an important control alternative. This study aimed to evaluate the agronomic performance of sweet potato genotypes in field and greenhouse. The work involves the assessment of two trials, the first on the agronomic performance and the second as the sweet potato resistance to root-knot nematodes Meloidogyne incognita and Meloidogyne paranaensis. The genotypes evaluated in both experiments were derived from the Germplasm Bank of Embrapa Vegetables (CNPH). The first experiment was conducted at Fazenda Água Limpa the University of Brasilia (UnB) and the second experiment at the Experimental Station of Biology of the UnB. The first experiment was conducted using the randomized complete block design with 10 treatments, 4 replicates and 10 plants of sweet potato/share. Were evaluated 10 genotypes: Princesa (CNPH 3), Brazlândia Rosada (CNPH 9), Santa Sofia (CNPH 17), CNPH 29, Georgia Improved (CNPH 31), Balão (CNPH 46), CNPH 53, Batata Africana 1 (CNPH 61), Batata Correntina ${ }^{\circ} 24$ (CNPH 66) and CNPH 71. The characteristics evaluated were: number of holes; incidence of damage; grade resistance; shape and length root; thickness and color of the shell; pulp color; total and commercial productivity; percentage of total soluble solids (SST/ ${ }^{\circ}$ brix); titratable acidity (ATT); ratio (TSS/ATT); moisture and starch income. The genotype $\mathrm{CNPH} 53$ had the highest estimated total productivity with 26,78 t/ha and the genotype Brazlândia Rosada stood out to commercial productivity estimated obtaining $13,75 \mathrm{t} / \mathrm{ha}$. The CNPH 71 performed best response in general with smallest number of holes $(9,09)$ and incidence of damage $(2,44)$, and had degree of resistance moderately susceptible. Also genotype Georgia Improved, Balão, CNPH 53, Batata Africana 1 and Batata Correntina $n^{\circ} 24$ were classified as moderately susceptible. The CNPH $29(158,89 \mathrm{~mm})$ showed better results for the length of the roots. The genotypes Brazlândia Rosada and Batata Africana 1 obtained the bigger thickness of the shell with $0,11 \mathrm{~cm}$. The genotype Georgia Improved $(1,87)$ and Santa Sofia $(1,92)$ showed the best formats. Of the ten genotypes studied only the CNPH 71 had shell color dark cream and only CNPH 53 had purple shell, for the rest $30 \%$ had cream color shell and $50 \%$ color pink shell. Regarding the color of the pulp, $80 \%$ presents the cream pulp and $20 \%$ dark cream. The genotype CNPH $53(12,25)$ showed the best result for the brix content. Regarding the acidity the results were 
higher: Santa Sofia (2,37 \%), CNPH 29 (2,53\%), CNPH $53(2,76 \%)$ and CNPH $71(3,10)$. The ratio reason of this study showed the best results for the treatment CNPH $53(4,42)$, Santa Sofia (4,25), CNPH 29 (4,24) and CNPH 71 (4,17), and the earliest genotypes from studied. Just Princesa $(70,18)$ and CNPH $29(70,91)$ presents moisture content close to $70 \%$. The genotypes CNPH 53 (11,98 \%), Princesa (11,38 \%), CNPH 29 (10,39 \%) and Georgia Improved $(9,78 \%)$ stood out as the most promising obtaining the highest percentages starch. Commercial productivity estimated, moisture and starch obtained heritability values above 90 $\%$ and values greater than 1 for the reason $\mathrm{CVg} / \mathrm{CVe}$, with indication of low environmental effect and effective selection for these characteristics, even using simple breeding methods. In the second experiment we used a randomized block in simple arrangement, with 10 treatments, 3 repetitions, 5 plants of sweet potato per plot to Meloidogyne incognita and 3 plants of sweet potato per plot for Meloidogyne paranaensis. We evaluated 10 genotypes: Princesa (CNPH 3), Roxinha (CNPH 5), Brazlândia Rosada (CNPH 9), Georgia Improved (CNPH 31), Balão (CNPH 46), CNPH 53, Batata Africana 1 (CNPH 61), Batata Correntina ${ }^{\circ}$ 24 (CNPH 66), CNPH 80 and Palmeira (CNPH 1796). The analyzed characteristics were: weight of shoot fresh mass, weight of shoot dry mass, weight of root fresh mass, number of eggs per share, number of eggs per plant, eggs per gram of root, number of egg masses, reproduction factor and degree of resistance. In the experiment with $M$. incognita the genotype CNPH 53 was the most promising for weight of shoot fresh mass $(14,33 \mathrm{~g})$, the genotype Georgia Improved stood out to the weight of shoot dry mass $(4,33 \mathrm{~g})$ and the genotype Brazlândia Rosada had the best performance for weight of root fresh mass $(12,64 \mathrm{~g})$. All genotypes studied showed resistant based on the analysis of the reprodution factor, but in relation to the number of egg masses these same genotypes showed susceptible. In the experiment with Meloidogyne paranaensis the genotype CNPH 53 showed the strongest both in relation to weight of shoot fresh mass $(26,39 \mathrm{~g})$, as for weight of shoot dry mass $(5,83 \mathrm{~g})$, while the genotypes Brazlândia Rosada (16,11 g) and Batata Correntina ${ }^{\circ} 24(15,00 \mathrm{~g})$ stood out to weight of fresh root mass. The genotype CNPH 80 showed resistant with respect to the mass number of eggs, and all other susceptible. The genotypes CNPH 80, Georgia Improved, Balão, Princesa and $\mathrm{CNPH} 53$ were resistant looking to reproduction factor, while the remainder were susceptible. The genotype CNPH 80 was the only one that demonstrated resistance to $M$. paranaensis both on the reproduction factor, as the number of egg masses.

Keywords: disease, cuttings, Ipomoea, root-knot nematodes, resistance, soil insects, productivity, root quality. 


\section{INTRODUÇÃO}

No ano de 2008 a batata-doce [Ipomoea batatas (L.) Lamarck] era cultivada em 114 países, sendo que aproximadamente $84 \%$ da produção era obtida na Ásia, $13 \%$ na África e 3\% no restante do mundo. Apenas $2 \%$ da produção se concentrava em países desenvolvidos como os Estados Unidos e Japão (FAO, 2008).

Atualmente grande parte da produção ainda se concentra no continente asiático, sendo a China o principal produtor, contabilizando em média 118 milhões de toneladas, numa área de 6 mil hectares. Enquanto isso, no Brasil as safras têm registrado bons índices se recuperando, uma vez que em 2009 com a produção de 477,5 mil toneladas, houve declínio, no comparativo com os períodos anteriores (CARVALHO et al., 2013).

Em 2011, o Brasil produziu 544,8 mil toneladas em 43,8 mil hectares, com variação positiva de 2,9\% em relação a 2010, quando foram colhidas 495,2 mil toneladas, apontam dados do Instituto Brasileiro de Geografia e Estatística (IBGE), referentes à Produção Agrícola Municipal (CARVALHO et al., 2013).

A batata-doce é cultivada em todas as regiões do país, com destaque para as regiões Sul e Nordeste. No ano de 2012, os estados do Rio Grande do Sul, Santa Catarina, Paraná, Sergipe, Ceará, Rio Grande do Norte e Paraíba obtiveram as maiores quantidades produzidas (toneladas) e rendimento médio ( $\mathrm{kg} / \mathrm{ha})$ do país. O estado de maior destaque é o Rio Grande do Sul, que possui 31\% da área plantada e concentra 32\% da produção total do país. Em 2013 o estado de Sergipe detinha a quinta maior produção do país (CARVALHO et al., 2013).

O cultivo relativamente simples e pouco dispendioso torna a batata-doce uma hortaliça muito popular e bastante consumida. Seu consumo per capita é bastante variado, desde 2 kg/hab/ano nos Estados Unidos a 114 kg/hab/ano no Burundi, localizado na África. Em 2013 o consumo per capita chegou a $2,7 \mathrm{~kg} / \mathrm{hab} / \mathrm{ano}$ no Brasil (CARVALHO et al., 2013).

No Nordeste, a cultura assume maior importância social por se constituir em uma fonte de alimento energético, de vitaminas e de proteínas, levando-se em conta a grande limitação na disponibilidade de outros alimentos em períodos críticos de estiagem prolongada. Além disso, a batata-doce tem grande importância na alimentação animal e na produção industrial de farinha, amido e álcool (SILVA et al., 2008).

A batata-doce tem elevado potencial de produção, pois produz grande volume de raízes em um ciclo relativamente curto, a baixo custo, durante o ano inteiro. É considerada uma cultura rústica, pois apresenta grande resistência a pragas, pouca resposta à aplicação de 
fertilizantes e cresce em solos pobres e degradados. Apesar disso, a batata-doce é suscetível a um grande número de doenças causadas por fungos, vírus, bactérias e nematoides, sendo também atacada por pragas, insetos e ácaros (MIRANDA et al., 1995; SILVA et al., 2008; RABELLO, 2010).

Segundo Rabello (2010), a utilização de nematicidas e inseticidas de solo nesta cultura não tem sido recomendada por ser ineficiente e antieconômica. Contudo, a utilização de germoplasmas de batata-doce resistentes ao nematoide das galhas e insetos de solo tem sido possível, constituindo-se uma importante alternativa de controle.

O uso de cultivares resistentes a doenças e pragas, associado a outras técnicas de manejo integrado, é a medida mais eficaz, econômica e ecológica de controle. O desenvolvimento de variedades resistentes é estratégico para todas as culturas agrícolas, visando à redução de custos de produção, segurança de trabalhadores agrícolas e consumidores, qualidade mercadológica, preservação do ambiente e sustentabilidade do agronegócio. A busca e a caracterização de fontes de resistência a doenças e pragas são o primeiro passo para a implementação e sucesso em programas de melhoramento genético (RABELLO, 2010).

Silva et al. (2008), afirmam que apesar de sua importância, são poucos os trabalhos de pesquisas visando selecionar e recomendar cultivares de batata-doce para diferentes regiões do país. Dessa forma o presente trabalho foi desenvolvido com os seguintes objetivos:

Objetivo geral: Avaliar o desempenho agronômico de genótipos de batata-doce em campo e casa de vegetação. Objetivos específicos: Avaliar 10 genótipos de batata-doce quanto à produtividade e a resistência a insetos de solo, nas condições do cerrado do Distrito Federal. Caracterizar a resistência de 10 genótipos de batata-doce aos nematoides das galhas Meloidogyne incognita e Meloidogyne paranaensis. 


\section{REVISÃO BIBLIOGRÁFICA}

\section{1 - Aspectos gerais da cultura}

\section{1 - Origem}

A batata-doce [Ipomoea batatas (L.) Lamarck] é uma espécie dicotiledônea pertencente à família botânica Convolvulaceae, com provável centro de origem nas Américas Central e Sul, sendo encontrada desde a Península de Yucatam no México até a Colômbia. Esta família agrupa aproximadamente 50 gêneros e mais de 1000 espécies, sendo que dentre elas, somente a batata-doce apresenta expressão econômica (SILVA et al., 2008).

A batata-doce era uma cultura bem estabelecida já na época pré-colombiana, como mostram registros da época da descoberta das Américas, estando dispersa por toda a América Tropical, tendo já alcançado os limites das regiões subtropicais do continente, o que sugere longo período evolutivo anterior a esta época. Isto é confirmado pelos vestígios arqueológicos de 2.000 a 2.500 antes de Cristo, encontrados no sul do México e do Peru, que sugerem que já neste período a batata-doce era cultivada por povos de etnias e culturas bastante diferenciadas (RITSCHEL et al., 1999).

Restos arqueológicos ainda mais antigos encontrados no Peru e datados de cerca de 10.000 a.C. também indicam a existência da espécie, sugerindo, portanto, que sua domesticação tenha coincidido com os primórdios do desenvolvimento da agricultura. Durante o longo período que antecede a descoberta das Américas por Colombo, portanto, a batata-doce se espalhou por todo o continente americano, através das rotas de migração humana (RITSCHEL et al., 1999).

Assim, a espécie passou por um longo processo evolutivo, que combinou a ação da seleção natural, representada pelo cultivo em diversos nichos ecológicos; a ação da seleção humana diferenciada, ditada pelos costumes e crenças dos vários povos que a cultivaram; a biologia peculiar da espécie; a possibilidade de reprodução sexuada e assexuada; resultando na diversidade de tipos e cores de raízes que são hoje conhecidas (RITSCHEL et al., 1999).

Atualmente, a maior variabilidade de tipos de batata-doce é encontrada no noroeste da América do Sul e no sul da América Central, nas regiões da Guatemala, Colômbia, Equador e Peru, habitadas na época pré-colombiana por povos extremamente hábeis nas práticas agrícolas. A região oeste do Brasil, que faz fronteira com a Bolívia, é mencionada por alguns autores como parte do centro secundário de diversidade da batata-doce; daí a necessidade da caracterização e avaliação dessa cultura (RITSCHEL et al., 1999). 


\section{2 - Morfologia}

A espécie $I$. batatas tem 90 cromossomos, sendo alógama, hexaplóide $(2 \mathrm{n}=6 \mathrm{X}=90)$, autoincompatível e propagada, em sua maior parte, por via assexuada. O mecanismo de autoincompatibilidade presente na espécie conduz à polinização cruzada e, portanto, a um alto grau de heterozigose. A polinização é, normalmente, feita por insetos e a autofecundação raramente ocorre (OLIVEIRA et al., 2002). Por isso, as sementes botânicas constituem uma imensa fonte de combinações genéticas e são utilizadas nos programas de melhoramento para obtenção de novas variedades (FOLQUER, 1978).

Silva et al. (2008), afirmaram que a planta possui caule herbáceo de hábito prostrado, com ramificações de tamanho, cor e pilosidade variáveis; as folhas largas com formato, cor e recortes variáveis; o pecíolo longo; as flores hermafroditas, mas de fecundação cruzada, devido à sua autoincompatibilidade; os frutos do tipo cápsula deiscente contendo duas, três ou quatro sementes com $6 \mathrm{~mm}$ de diâmetro e cor castanho-clara. Da fertilização da flor à deiscência do fruto transcorrem seis semanas.

A batata-doce possui dois tipos de raiz: a de reserva ou tuberosa, facilmente identificada por possuir maior espessura, constituindo a principal parte de interesse comercial e a raiz absorvente responsável pela absorção de água e extração de nutrientes do solo. As raízes tuberosas são revestidas por uma pele fina (composta por poucas camadas de células), pela casca (espessura de aproximadamente $2 \mathrm{~mm}$ ) e pela polpa ou carne localizada na parte central que constitui a maior parte da raiz (SILVA et al., 2008).

As raízes podem apresentar o formato redondo, oblongo, fusiforme ou alongado. Podem conter veias, dobras e possuir pele lisa ou rugosa. A pele, casca e polpa podem apresentar coloração variável de roxo, salmão, amarelo, creme ou branco. A coloração arroxeada é formada pela deposição do pigmento antocianina e a cor amarela-alaranjada pela concentração de betacaroteno (SILVA et al., 2008).

\section{3 - Formas de propagação}

Segundo Silva et al. (2008), a reprodução de batata-doce pode ser feita de três maneiras distintas: por meio de batatas, ramas-semente ou estacas e mudas. A reprodução por meio de batatas consiste em promover a brotação de batatas selecionadas, para posterior utilização destas brotações. As estacas são retiradas de uma cultura em desenvolvimento. As mudas podem ser obtidas cultivando-se uma área como viveiro para obtenção das mesmas. 
As batatas ou raízes tuberosas possuem a capacidade de desenvolver gemas vegetativas que se formam a partir do tecido meristemático localizado na região vascular, quando a raiz é destacada da planta ou quando a parte aérea é removida ou dessecada (SILVA et al., 2008). Ao contrário da batata comum e de outras espécies tuberosas, a raiz de batatadoce não possui gemas ou qualquer outra estrutura diferenciada na polpa enquanto estiver ligada a planta. Após a colheita, a raiz inicia um processo de transformação interna, na região denominada vascular para gerar gemas a partir dos tecidos meristemáticos (BRUNE, 2005). Ou seja, ocorre a formação das gemas quando são eliminados os pontos de crescimento da parte aérea, anulando o efeito da dominância apical (SILVA et al., 2008). Portanto, é necessário armazenar as batatas em local ventilado e fresco por alguns dias, antes de colocálas para multiplicação. O uso de raízes tuberosas na multiplicação tem o grande inconveniente de permitir a disseminação de pragas e doenças (BRUNE, 2005).

O caule, mais conhecido como rama, pode ser segmentado e utilizado como ramasemente ou estaca para formação de lavoura. As estacas têm capacidade de emitir raízes em tempo relativamente curto, que pode variar de três a cinco dias, dependendo da temperatura e da idade do tecido. É recomendado que as ramas-sementes sejam coletadas em lavouras em formação com até 90 dias do plantio, retirando um ou dois pedaços por haste, a partir da sua extremidade (BRUNE, 2005). As ramas devem ser retiradas das partes mais novas do caule, até cerca de $60 \mathrm{~cm}$ da extremidade, por se enraizarem mais rápido devido ao menor teor de lignina e maior número de células meristemáticas, também por serem menos contaminadas por pragas e patógenos, especialmente os fungos localizados no solo (SILVA et al., 2008). No período compreendido entre o corte da rama-semente e o início do seu enraizamento no campo, a rama-semente está sujeita à desidratação, mesmo que o solo contenha um pouco de umidade. Por isso, é necessário manter o solo com alto teor de umidade na primeira semana após o plantio (BRUNE, 2005).

As mudas são obtidas a partir de cultivo em viveiro de plantas matrizes, livres de patógenos, devendo ser mantidas protegidas com tela à prova de insetos, de onde se obtêm plantas que podem ser reproduzidas em campo. Os viveiros devem ser instalados em áreas isoladas dos campos de produção, mas ainda não se tem um parâmetro para esse isolamento. Já existem plantas sadias à disposição de quem queira realizar este investimento, que corresponde a um custo relativamente baixo (SILVA et al., 2008). 


\section{4 - Condições edafoclimáticas}

A batata-doce é cultivada em locais de climas diversos como o das Cordilheiras dos Andes, em regiões de clima tropical como o da Amazônia, temperado como o do Rio Grande do Sul e até desértico como o da costa do Pacífico. Porém, a cultura adapta-se melhor em áreas tropicais (SILVA et al., 2008).

A cultura desenvolve-se melhor em locais ou épocas em que a temperatura média é superior a $24^{\circ} \mathrm{C}$, pois temperaturas inferiores a $10^{\circ} \mathrm{C}$ retardam o crescimento da planta. A batata-doce não tolera geada, porém pode ser cultivada em regiões temperadas, durante a primavera e verão, quando a temperatura elevada e a alta radiação solar favorecem o desenvolvimento da cultura (SILVA et al., 2008).

Essa espécie deve ser implantada em locais com pluviosidade anual média de 750 a $1000 \mathrm{~mm}$, necessitando de cerca de $500 \mathrm{~mm}$ de lâmina de água durante o ciclo produtivo para que apresente um índice elevado de produtividade. A fase crítica de disponibilidade de umidade no solo ocorre na primeira semana após o plantio. Em termos práticos, recomenda-se irrigar duas vezes por semana até os 20 dias, uma vez por semana dos 20 aos 40 dias e a cada duas semanas após os 40 dias até a colheita (MIRANDA et al., 1995).

O solo deve ser preferencialmente arenoso, bem drenado, sem presença de alumínio tóxico, com pH ligeiramente ácido e com alta fertilidade natural. Solos arenosos facilitam o crescimento lateral das raízes e evita à formação de batatas tortas ou dobradas. Além disso, facilita a colheita e permite o arranquio das batatas com menor índice de danos e menor esforço físico (SILVA et al., 2008).

Quanto à topografia, a utilização de áreas de pouco declive facilita as operações mecanizadas. No entanto, áreas relativamente acidentadas também podem ser utilizadas, pois a construção de leiras em nível promove um controle eficiente da erosão do solo (SILVA et al., 2008).

A batata-doce apresenta pouca resposta à aplicação de fertilizantes. Possui um sistema radicular muito ramificado, tornando-se eficiente na absorção de nutrientes, especialmente o fósforo. Quando plantada após uma cultura que tenha recebido adubação, geralmente não necessita de fertilizações e correções do solo. Porém, como toda cultura extrai elementos, esses devem ser fornecidos ao solo com a finalidade de manter a sua capacidade produtiva (SILVA et al., 2008). 


\section{5 - Cultivares}

Existe no Brasil um elevado número de cultivares de batata-doce, com enorme diversidade genética entre elas. Praticamente, em todos os municípios brasileiros existem cultivares locais. É comum encontrar uma mesma cultivar com nomes diferentes, ou diferentes cultivares com o mesmo nome. Há, por exemplo, dezenas de cultivares com o nome de Rainha (MIRANDA et al., 1995).

As cultivares diferenciam-se principalmente quanto à cor da casca, cor da polpa e formato, sendo a preferência popular variável. Geralmente as batatas comercializadas nos grandes centros urbanos têm polpa branca ou creme e película externa rosa, roxa ou branca (MIRANDA et al., 1995). O produtor deve escolher aquela que seja mais aceita no mercado onde pretende vender a produção, pois a preferência é variável de local para local. Além disso, em cada região produtora existem variedades locais (SILVA et al., 2008).

As cultivares recomendadas estão estreitamente relacionadas ao local e a época de plantio, adubação, finalidade da produção e a preferência do mercado consumidor. Algumas regiões têm indicação própria de cultivares tais como: Brazlândia Rosada e Coquinho que são selecionadas e liberadas pelo CNPH para o cultivo em Brasília, possuindo excelente qualidade agronômica e comercial, com boa adaptabilidade as diferentes regiões brasileiras (MIRANDA et al.1995).

Antes do plantio é necessário conhecer a adaptabilidade de cultivar as condições climáticas da região, suas características de resistência a pragas e doenças e às características de desenvolvimento da planta (SILVA et al., 2008).

\section{6 - Colheita}

A planta da batata-doce não apresenta um ponto específico de colheita. Existem várias maneiras para se determinar o ponto de colheita ou maturação da batata-doce que, sendo essa uma raiz, não atinge a maturação no verdadeiro sentido do termo. A finalidade da produção e a demanda do produto pelo mercado são duas maneiras de definir esse momento (MIRANDA et al.,1995).

Para consumo humano, o momento da colheita pode ser definido pelo tamanho ou peso das raízes (aproximadamente $300 \mathrm{~g}$ ) e deve ser realizada assim que as raízes atinjam a dimensão exigida pelo mercado. Em condições ideais de cultivo a colheita pode se iniciar aos 90 dias, mas em geral, ocorre entre 120 e 150 dias após o plantio variando em função do local e época de plantio, cultivar, espaçamento e adubação. A colheita pode ser antecipada ou 
retardada, dependendo da oportunidade de comercialização (MIRANDA et al., 1995; SILVA et al., 2008).

Para indústria, a batata pode ser colhida mais tarde com as raízes atingindo maior peso médio. Para forragem animal, também deve ser colhida mais tarde, pois nesse caso o que interessa é a produção de matéria seca por unidade de área (MIRANDA et al., 1995).

A colheita pode ser feita manualmente ou mecanicamente. Geralmente são utilizados equipamentos semelhantes aos arados, modificados para facilitar a separação do solo, tendo a frente um disco vertical para cortar as ramas. As máquinas utilizadas na colheita de batata (Solanum tuberosum) podem ser usadas com sucesso. De qualquer maneira sempre envolve muita mão-de-obra, mesmo quando algumas etapas são mecanizadas (MIRANDA et al., 1995; SILVA et al., 2008).

\section{2 - Aspectos socioeconômicos}

A produtividade média do Brasil é muito abaixo daquela obtida em outros países. Dentre os motivos para essa baixa produtividade destacam-se o uso de variedades pouco produtivas e o baixo nível tecnológico empregado (SILVA et al., 2008).

A batata-doce tem sido cultivada em pequena escala, com pouco uso de tecnologia e sem orientação profissional, obtendo-se baixos índices de produtividade e baixa qualidade dos produtos. Esse fato está relacionado às técnicas de cultivo, já que ao longo do tempo a batatadoce foi cultivada de forma empírica pelas famílias rurais, em conjunto com diversas outras culturas, visando à alimentação familiar (SILVA et al., 2008).

No início da década de 60, sua área plantada era de aproximadamente 180.000 ha, caindo consideravelmente nas últimas décadas. Além da plena decadência na área de plantio, verificou-se uma perda média de produtividade de 2 toneladas/ha durante este período (GUEDES, 1980; MIRANDA et al., 1995).

Enquanto a produção se recupera do declínio nas últimas décadas, percebe-se que o índice de produtividade tem sido crescente nos últimos anos. Em 2009, os bataticultores brasileiros colheram 11,3 t/ha. No ano seguinte foram 11,8 t/ha e em 2011 atingiu 12,4 t/há (IBGE, 2012). Os números demonstram, sobretudo, as mudanças sofridas pelo sistema de produção indicando evolução do nível tecnológico. Em 2012 o Brasil exportou 2.811 .180 kg de batata-doce, o equivalente a um total de US\$ 1.812 .538 arrecadados para o país (CARVALHO et al., 2013). 
No Brasil, a batata-doce é cultivada em todas as regiões. Embora bem disseminada no país, está mais presente nas regiões Sul e Nordeste, notadamente nos estados do Rio Grande do Sul, Santa Catarina, Paraná, Pernambuco e Paraíba (SILVA et al., 2008). No nordeste a batata-doce é uma cultura bastante difundida e cultivada, sendo consumida pelos produtores e o excedente é comercializado em mercados locais ou nos estados vizinhos (PEREIRA et al., 2003).

Em 2008 a região Centro-oeste se destacou produzindo cerca de 1.708 toneladas da raiz, sendo o Distrito Federal o maior produtor, com $76 \%$ da produção da região (IBGE, 2012).

Segundo os resultados da pesquisa Produção Agrícola Municipal (PAM), referente ao ano de 2012 elaborados pelo IBGE, a região Nordeste foi a mais produtiva seguida pelas regiões Sul e Sudeste. Aproximadamente $29 \%$ da área plantada (ha) do país compreendem os estados nordestinos de Sergipe, Ceará, Rio Grande do Norte e Paraíba e em torno de $41 \%$ da área plantada se encontra na região sul. Somente o Rio Grande do Sul possui uma quantidade próxima de $31 \%$ da área plantada e concentra $32 \%$ da produção (toneladas) total do país (IBGE, 2012).

Como produto de grande importância social, a batata-doce contribui de maneira decisiva para o suprimento alimentar das regiões mais pobres do planeta, sendo considerada uma cultura de subsistência desempenhando grande importância para populações de baixa renda, onde é produzida geralmente com pouca ou nenhuma tecnologia e em pequenas áreas marginais (COIMBRA, 2006).

\section{3 - Informações nutricionais}

A batata-doce é o sétimo produto mais importante do mundo, considerando-se os cultivos que proporcionam alimentos básicos, estando atrás apenas do trigo (Triticum aestivum), arroz (Oryza sativa), milho (Zea mays), batata (Solanum tuberosum), cevada (Hordeum vulgare), e mandioca (Manihot esculenta Crantz.) (MANO et al., 2007).

A utilização da batata-doce (Ipomoea batatas) no mundo vem sendo destinada prioritariamente para o consumo humano e animal. No Brasil, 50\% da produção está voltada para alimentação humana e $40 \%$ para alimentação animal, embora possa ser utilizada também para fim industrial (NUNES, 2012).

As ramas da batata-doce podem ser utilizadas na alimentação animal na forma de forragem verde ou de silagem. Os resíduos culturais como ramas, raízes finas e tuberosas não comercializáveis são, às vezes, descartados, no entanto, esses resíduos podem ser 
aproveitados como alimento animal, chegando a representar mais de 50\% da fitomassa total do cultivo. Deles há ainda a oportunidade do consumo dos brotos na alimentação humana (KALKMANN, 2011).

A batata-doce apresenta em média $70 \%$ de umidade, $0,61 \%$ de fibras, $26 \%$ de carboidratos e $1,05 \%$ de cinzas, enquanto as raízes de mandioca apresentam em média $62 \%$ de umidade, $1,3 \%$ de fibras, $34 \%$ de carboidratos e 1,1\% de cinzas (KALKMANN, 2011). Ao ser colhida, apresenta cerca de $30 \%$ de matéria seca que contém em média $85 \%$ de carboidratos, cujo componente principal é o amido. Comparada com outras estruturas vegetais amiláceas possui maior teor de matéria seca, carboidratos, lipídios, cálcio e fibras que a batata, mais carboidratos e lipídios que o inhame e mais proteína que a mandioca (FOLQUER, 1978; WOOLFE, 1992).

Em termos nutricionais a raiz da batata-doce destaca-se principalmente por seu alto conteúdo energético. É uma cultura rica em carboidratos (13,4\% a 29,2\%), principalmente amido, e em açúcares redutores (4,8\% a 7,8\%). Cada 100 gramas da raiz possuem de 110 a 125 calorias, baixos teores de proteína $(2,0 \%$ a $2,9 \%)$ e de gorduras $(0,3 \%$ a $0,8 \%)$. A batatadoce também é fonte de minerais fornecendo, a cada 100 gramas, os seguintes teores: cálcio (30mg), fósforo (49mg), potássio (273mg), magnésio (24mg), enxofre (26mg), sódio (13mg), vitaminas A, C e do complexo B (MIRANDA et al., 1995). O conteúdo proteico é geralmente baixo (1-2\% da massa seca), mas o padrão do conteúdo de aminoácidos essenciais é bastante razoável, com grande quantidade de metionina, que é um dos aminoácidos essenciais para o bem estar dos seres humanos (MIRANDA et al., 1995; RITSCHEL et al., 1999; KALKMANN, 2011).

Dados bioquímicos disponíveis no país confirmam que a deficiência de vitamina A tem sido um problema de saúde pública no Brasil nos últimos 20 anos, principalmente nas regiões do Norte, Nordeste e Sudeste (RAMALHO et al., 2002).

A batata-doce é uma raiz muito presente na dieta de populações sujeitas à restrição alimentar, sendo, portanto, uma alternativa para melhorar a nutrição dessas pessoas (SILVA et $a l ., 2010)$. No Brasil, as variedades de batata-doce comercializadas são predominantemente de cor de polpa branca, amarela e creme. Raramente são encontradas batatas-doces de polpa alaranjada, as quais são ricas em carotenoides, sendo o seu consumo do ponto de vista nutricional mais interessante (MELO et al., 2011).

Os carotenoides são os pigmentos que conferem as cores laranja, vermelha e amarela aos vegetais. Entre os carotenoides presentes em raízes de batata-doce destaca-se o 
betacaroteno, que é o mais potente precursor de vitamina A encontrado em plantas (KALKMANN, 2011). Após ser ingerido pelo organismo humano, o betacaroteno se transforma em vitamina A, que é essencial para o desenvolvimento dos órgãos da visão, formação da pele e crescimento do corpo (MELO et al., 2011).

Assim, variedades de batata-doce que apresentem níveis mais altos dessa vitamina podem contribuir para sanar esse problema alimentar, uma vez que é um produto de baixo custo e que atende ao paladar da população brasileira.

\section{4 - Diversificação no uso da cultura}

A batata-doce é uma cultura com multiplicidade de uso. Todas as partes da planta são utilizadas: as ramas e raízes tuberosas são consumidas em larga escala para a alimentação humana e animal, assim como serve de matéria-prima nas indústrias de alimento, tecido, papel, cosmético, preparação de adesivos e álcool carburante (FORTES, 2010).

No Brasil são relatadas experiências com a fabricação e emprego de farinha de batatadoce (GUEDES et al., 1980; NUNES, 2012). A produção de farinhas apresenta grande variabilidade para a indústria de alimentos, principalmente em produtos de panificação, produtos dietéticos e alimentos infantis, por serem rica fonte de amido e sais minerais (NUNES, 2012).

Há também, no Brasil, tecnologias para a fabricação de produtos tais como "chips" secos e fritos, iogurte de batata-doce, flocos desidratados, enlatados, entre outros, em pequena, média e grande escala disponíveis. Estima-se que cerca de 60 produtos diferentes possam ser fabricados com o uso de raízes de batata-doce (KALKMANN, 2011).

Além desses importantes empregos da batata-doce, pode-se ainda ressaltar a comercialização do tubérculo sob a forma de produtos congelados processados e semiprocessados no Japão. No Taiwan e no Peru mais de $50 \%$ do total colhido é destinado à produção de fécula, de álcool e a substituição de até $15 \%$ da farinha de trigo por farinha de batata-doce, sem prejuízo das propriedades físicas do produto final. Nos Estados Unidos, é muito consumida não só no estado fresco, como também em enlatados, flocos, purês, doces, sorvetes, geleias e xaropes (KALKMANN, 2011).

A utilização dos "combustíveis limpos" não derivados de petróleo e fontes minerais, pode impulsionar a produção de álcool a partir da batata-doce no Brasil, com a vantagem de não poluir. Como fonte alternativa de bioenergia, a batata-doce apresenta uma ótima produção 
de biomassa para obtenção de álcool combustível, associada à rusticidade do plantio (EMYGDIO \& CASTRO, 2010).

Resultados preliminares têm demonstrado que um hectare de raiz de batata-doce rende de 30 a 40 toneladas de biomassa. Enquanto uma tonelada de cana-de-açúcar gera 67 litros de álcool, a mesma quantidade de batata-doce chega a até 130 litros do combustível. Além disso, também pode representar um incremento na geração de empregos e diminuição dos danos ambientais causados pelo petróleo e pela cana-de-açúcar (EMYGDIO \& CASTRO, 2010).

Segundo estudo de Leonel \& Cereda (2002), a batata-doce apresenta 14,72\% de amido (base úmida) e possui rendimento potencial de amido de 2,9 ton/ha. Ainda no mesmo estudo, constatou-se na batata-doce a presença de elevado teor de açúcares totais e redutores o que a torna uma matéria-prima utilizável não somente para a extração do amido, mas para a produção de hidrolisados e fermentados. Entre estes últimos, pode-se citar a produção de álcool como um dos usos mais promissores para a batata-doce devido às suas características favoráveis como: um ciclo curto de produção (4 a 5 meses), rusticidade no campo, adaptada às condições tropicais, possibilidade de produção em condições de solo de baixa a média fertilidade e principalmente baixo custo de produção, privilegiando os pequenos produtores rurais (SOUZA et al., 2005).

O uso da fécula de batata também tem se mostrado bastante promissor, podendo ser usada como espessante, uma vez que apresenta grande quantidade de amido gelatinizável, também atua como estabilizante e é capaz de melhorar o substrato para os microrganismos responsáveis pela fermentação (KALKMANN, 2011). Os grânulos de amido, quando hidratados e aquecidos à temperatura suficiente, sofrem um processo irreversível chamado de gelatinização, podendo ser observadas modificações acentuadas na solubilidade e propriedades mecânicas do amido, como um aumento na viscosidade da solução (KALKMANN, 2011).

Apesar de tanta utilidade industrial, o cultivo da batata-doce praticamente se restringe ao nível de subsistência, a maior parte da produção vem sendo destinada prioritariamente para o consumo humano e animal. Algumas causas possíveis podem ser o conhecimento ainda incipiente sobre a composição química das raízes dessa hortaliça, especialmente se comparado àquele disponível para grandes culturas, como o milho, e também a falta de disponibilidade de genótipos selecionados especificamente para fins industriais (RITSCHEL et al., 1999). 


\section{5 - Nematoides e insetos de solo que atacam a batata-doce}

As espécies de Meloidogyne constituem uma pequena parte do Filo Nemata (ou Nematoda), que compreende os nematoides em geral, incluindo os parasitas do homem, dos animais e de plantas, além de espécies de vida livre no solo, na água doce e no mar. O gênero Meloidogyne faz parte da classe Chromadorea, ordem Rhabditida, Subordem Tylenchina, Infraordem Tylenchomorpha, Superfamília Tylenchoidea e família Meloidogynidae (MATTOS, 2013).

A palavra Meloidogyne é de origem grega e significa "fêmeas em forma de maçã". Eles são um grupo de polífagos economicamente importantes, parasitas obrigatórios de plantas e altamente adaptados. São distribuídos em todo o mundo e quase todos parasitam espécies de plantas superiores. Normalmente eles se reproduzem e alimentam dentro de células vegetais vivas modificadas, nas raízes das plantas, onde eles induzem a formação de galhas (CARMONA, 2015; MOENS et al., 2009).

O ciclo de vida do nematoide das galhas tem início com a ovoposição das fêmeas, quando depositam seus ovos no interior de uma massa gelatinosa composta de glicoproteína, produzida por glândulas retais da fêmea, na qual os ovos se mantêm unidos e protegidos contra condições ambientais adversas e predação, além de apresentar propriedades antimicrobianas. As massas de ovos são geralmente encontradas na superfície de raízes galhadas (MOENS et al., 2009; MATTOS, 2013).

No interior dos ovos ocorre a embriogênese havendo a diferenciação para o primeiro estádio juvenil (J1). Em seguida ocorre a primeira ecdise dentro do ovo originando o segundo estádio juvenil infeccioso (J2). Após a eclosão o J2 se locomove para o solo e localiza um hospedeiro penetrando em suas raízes para se alimentar e desenvolver (MOENS et al., 2009).

De maneira geral, o J2 eclode quando há condições ambientais favoráveis à sua sobrevivência, tais como disponibilidade de oxigênio e umidade no solo adequados, temperatura apropriada e ausência de barreiras fisiológicas, como, por exemplo, a diapausa. Nesse estádio móvel, vermiforme e infectante migra através do solo atraído por substâncias emanadas pelas plantas, penetrando nas raízes da planta hospedeira. Há evidências de que quando presentes raízes de plantas resistentes e suscetíveis, as suscetíveis são mais atraentes (MATTOS, 2013).

O início da alimentação do $\mathrm{J} 2$ em células do protoxilema e protofloema induz a diferenciação das mesmas em células especializadas, chamadas células gigantes. Uma vez que as células gigantes são iniciadas, o nematoide torna-se sedentário e ocorre então à segunda (J2 $>\mathrm{J} 3)$, a terceira $(\mathrm{J} 3>\mathrm{J} 4)$ e a quarta ecdises (J4 > fêmea jovem). Logo após a última ecdise, a 
fêmea jovem começa a se alimentar, permanecendo ali o restante de sua vida. Ocorre a hiperplasia e hipertrofia das células comprometidas resultando, via de regra, na formação da galha radicular (MATTOS, 2013).

Os juvenis do terceiro e quarto estádio (J3 e J4) não se alimentam devido à falta de um estilete funcional. Na última ecdise, os nematoides machos tornam-se longos e filiformes, revestidos externamente pela cutícula do quarto estádio juvenil. Os machos então escapam da última cutícula juvenil e se movem livremente no solo e não há nenhuma evidência de que se alimentem. Eles são frequentemente encontrados na matriz gelatinosa onde copulam as espécies anfimíticas. As fêmeas adultas se mantêm sedentárias e continuam a se expandir à medida que amadurecem, tornando-se piriformes, produzindo grandes números de massas de ovos e consequentemente ocasionando a formação das galhas. $\mathrm{O}$ tempo requerido para completar o ciclo de vida depende das condições ambientais prevalentes e da suscetibilidade do hospedeiro. As fêmeas produzem ovos por três semanas, depois cessam a produção, podendo viver um pouco mais. Os machos vivem semanas e os $\mathbf{J} 2$ podem viver de poucos dias a meses (MATTOS, 2013; CARMONA, 2015; MOENS et al., 2009).

$\mathrm{Na}$ maioria das vezes a reprodução é partenogênica. Os machos podem ser encontrados em espécies partenogenéticas quando: as condições são desfavoráveis para o desenvolvimento da fêmea, há resistência da planta hospedeira, a densidade populacional é muito alta e há uma limitação da oferta de alimentos. Esse fenômeno é conhecido por reversão sexual e é um dos mecanismos de sobrevivência desses nematoides, pois menos ovos serão produzidos e o parasitismo sobre a planta infectada será mais brando, garantindo a sobrevivência das fêmeas formadas (MOENS et al., 2009; MATTOS, 2013).

A verificação de populações mistas e/ou detecção de espécies raras exige que sejam executadas técnicas de identificação morfológica (padrão perineal de fêmeas adultas; morfologia do estilete; formato da região labial feminina, masculina e J2; comprimento e forma da cauda do J2) e metodologias bioquímicas ou moleculares, dentre outras (HUNT et al., 2009).

O sintoma característico da infecção por nematoide do gênero Meloidogyne sp. é a presença de galhas nas raízes. Na batata-doce, são muito menores (1-2 mm de diâmetro), em relação às galhas observadas nas raízes de outras plantas hospedeiras, podendo ser até mesmo não distinguíveis visualmente. $\mathrm{O}$ tamanho das galhas varia entre as cultivares de batata-doce, e em muitos casos, quando muito pequenas, dificultam sua visualização (PINHEIRO, 2012). 
Níveis populacionais altos diminuem a absorção de nutrientes e água pela planta, reduzindo a produtividade. Raramente são observadas galhas nas raízes tuberosas, com exceção de genótipos altamente suscetíveis, o que acaba por depreciar o valor comercial dessas cultivares (PINHEIRO, 2012). Além disso, a batata-doce pode apresentar sintomas secundários tais como: redução de crescimento, amarelecimento das folhas, murcha temporária e florescimento anormal que são causados pela ineficiência do sistema radicular infestado por nematoides. Entretanto, em função do grande vigor vegetativo e da capacidade de enraizamento ao longo das ramas (raízes adventícias) é raro se observarem sintomas na parte aérea que se relacionem com o ataque de nematoides (SILVA et al., 2008).

Vários gêneros de fitonematoides estão associados aos cultivos de batata-doce, porém o nematoide das galhas (Meloidogyne spp.) e o nematoide reniforme (Rotylenchulus reniformis) são os principais causadores de danos econômicos. No entanto, dois gêneros de endoparasitos migradores, Pratylenchus (nematoide-das-lesões-radiculares) e Ditylenchus (nematoide-do-alho), também são encontrados ocasionalmente, podendo em determinadas situações, reduzir a qualidade ou produção das plantas infectadas (PINHEIRO, 2012).

O nematoide Rotylenchulus reniformis, um semiendoparasita sedentário, nas últimas três décadas foi considerado um importante patógeno da batata-doce, afetando o rendimento e a qualidade da cultura. Este patógeno ocorre principalmente em regiões tropicais e subtropicais e também em algumas áreas temperadas, porém não é amplamente distribuído como o nematoide das galhas. É encontrado no Brasil e em vários países da América do Sul, Central e Norte, África, Europa e Ásia (PINHEIRO, 2012).

O nematoide reniforme infecta as raízes da batata-doce em qualquer fase do desenvolvimento, sendo os sintomas difíceis de distinguir daqueles causados por outros patógenos, pois não há presença de galhas. No entanto, em altas densidades populacionais as raízes podem tornar-se mais curtas, apresentar menor número de raízes secundárias e na estação de crescimento as raízes tuberosas atacadas podem tornar-se necróticas. Os sintomas secundários são semelhantes aos causados pelo gênero Meloidogyne sp. resultando em amarelecimento da folhagem, murcha acentuada das plantas e raízes rachadas e distorcidas (PINHEIRO, 2012).

No Brasil, várias espécies de nematoides Meloidogyne têm sido observadas em diversos campos de produção, mas especialmente $M$. javanica e $M$. incognita raças 1, 2, 3 e 4 vêm sendo encontrados de forma mais frequentes tornando-se os mais importantes. As espécies $M$. arenaria e $M$. hapla ocorrem com menor frequência em batata-doce no Brasil. 
São amplamente disseminados, causando danos em dezenas de espécies vegetais cultivadas e plantas voluntárias, assim como na batata-doce reduzindo o rendimento e a qualidade das raízes tuberosas (SILVA et al., 2008; PINHEIRO, 2012).

As culturas agrícolas geralmente são melhores hospedeiras de nematoides do que as plantas daninhas. A maioria das espécies de nematoides possui uma ampla gama de hospedeiros em comum. As espécies $M$. arenaria, M. hapla, M. incognita e M. javanica tem muitos hospedeiros em comum, incluindo hortaliças como o tomate, considerado um hospedeiro universal de Meloidogyne spp. Dessas quatro espécies, apenas algumas populações de $M$. incognita parasitam algodão. O Meloidogyne hapla parasita a maioria das gramíneas e culturas de grãos. O amendoim é um bom hospedeiro para o M. hapla e para a maioria das populações de $M$. arenaria, mas não para $M$. incognita. A maioria das populações de $M$. javanica nos EUA não se reproduzem bem em amendoim, mas populações desta espécie na Índia e no norte África geralmente conseguem se reproduzir em amendoim satisfatoriamente (MOENS et al., 2009).

Não há relatos na literatura a respeito da resistência da cultura de batata-doce a Meloidogyne paranaensis. Esse patógeno foi descrito pela primeira vez em cafezais no Brasil no estado do Paraná em 1996, somando-se ao grupo dos nematoides fitoparasitas mais importantes no país (PERES, 2013). Atualmente, existem quatorze espécies de Meloidogyne que parasitam o cafeeiro das quais seis ocorrem no Brasil (M. paranaensis, M. incognita, $M$. exigua, M. coffeicola, M. goeldii e M. hapla). As mais prejudiciais são $M$. paranaensis e $M$. incognita pela intensidade dos danos que causam e $M$. exigua pela ampla distribuição geográfica (SERA et al., 2007).

O café (Coffea arabica L.) é o hospedeiro primário desta espécie, no entanto, esse nematoide também tem sido detectado em soja. Em estudos de hospedeiros o tabaco, a tomate, a melancia e a erva-mate (Ilex paraguariensis) também foram notificados como hospedeiros, assim como espécies de Solanaceaes, Cucurbitaceas e Aquifoliaceas. Atualmente o nematoide foi detectado apenas nos EUA (incluindo Hawaii), América Central, Caribe, Guatemala e América do Sul (MOENS et al., 2009).

A diversidade de espécies de insetos associados à batata-doce e parentes silvestres próximos na América é atribuída ao fato de que o centro de origem de várias espécies do gênero Ipomoea é localizado nas Américas do Sul e Central (FRANÇA \& RITSCHEL, 2002). 
As pragas-chave da batata-doce são a broca-da-raiz (Euscepes postfasciatus) e a broca-das-hastes (Megastes pusialis), ocorrendo com maior frequência e geralmente causando danos severos se não forem tomadas medidas de controle (SCHRAMMEL, 2011).

Tem-se registrado cerca de 270 espécies de insetos atacando essa cultura no campo e no armazém em todo o mundo e apesar de não serem comuns altos níveis de danos em culturas bem conduzidas, os danos podem ser elevados, caso o manejo não seja adequado chegando a perdas de $60 \%$ a 100\% da produção (WANDERLEY, 2004).

A espécie E. postfasciatus, pertence a ordem Coleoptera e a família Curculionidae, é considerada cosmopolita, estando presente na América do Sul e Central, nas Índias Ocidentais/Antilhas, Caribe e áreas do Atlântico Norte, Pacífico Norte e Sul. Os registros de hospedeiros silvestres de E. postfasciatus são poucos, além da batata-doce, tem sido registrada em poucas espécies de plantas do mesmo gênero. No Havaí, I. pentaphylla, I. triloba, I. horsfalliae e I. reptans foram registradas como hospedeiras (MENEZES, 2002).

A postura é realizada pelas fêmeas que deposita seus ovos nas ramas da batata-doce, de preferência nos "nós" (gemas) e partes mais grossas junto ao colo (base do caule) da planta ou nas raízes tuberosas, principalmente naquelas localizadas a cerca de $2 \mathrm{~cm}$ da superfície do solo. O ciclo evolutivo (fases de ovo, larva, pré-pupa e pupa) dessa espécie dura em média 38 dias, variando de 32 a 46 dias, dependendo principalmente da temperatura e alimento disponível, estando a maior parte do tempo localizado no interior das ramas e raízes tuberosas de batata-doce (MENEZES, 2002).

As larvas passam por cinco instares, medindo cerca de $0,5 \mathrm{~mm}$ de comprimento quando recém-nascidas e atingem de 4 a $5 \mathrm{~mm}$ de comprimento quando completamente desenvolvidas. O período larval dura em média 21 dias, variando de 18 a 24 dias. O dimorfismo sexual é difícil de ser observado, pois ambos os sexos são aparentemente similares, porém, às vezes, as fêmeas são maiores que os machos, embora as condições nutricionais dos insetos possam mascarar essa diferença. Os adultos são desprovidos da capacidade de voar o que torna extremamente lenta a sua dispersão natural (MENEZES, 2002).

A broca-da-raiz causa danos tanto na superfície das raízes, quanto na polpa, depreciando comercialmente o produto final e inviabilizando o consumo animal e humano, sendo responsável por perdas de até $50 \%$ da produção (RICCI, 2011). As larvas atacam tanto as ramas quanto as raízes, escavando galerias, onde são depositados os dejetos fecais. Os adultos saem das galerias e fazem a desova na mesma raiz, de forma que muitas vezes pode-se 
encontrar centenas de indivíduos em uma só raiz. O ataque severo pode até causar a morte das partes aéreas da planta (SILVA et al., 2008).

As batatas intensamente atacadas apodrecem ou mostram-se com o aspecto físico, cheiro e sabor bastante alterados, tornando-se imprestáveis para o consumo. É fácil identificar quando a batata-doce é atacada, pois a sua casca se torna escura e apresenta uma leve depressão na extensão das galerias (SILVA et al., 2008).

A broca das hastes $M$. pusialis, pertencente à ordem Lepidoptera e família Crambidae, está presente no Brasil e foi registrada nos estados da Bahia, Goiás, Minas Gerais, São Paulo e Rio de Janeiro. Essa espécie também foi registrada em várias províncias da Costa Rica. Embora a broca das hastes, particularmente possa se alimentar de outras convolvuláceas em condições de laboratório, a batata-doce é a única espécie conhecida como planta hospedeira (MENEZES, 2003).

No campo a fêmea realiza a postura de seus ovos durante a noite nas axilas das folhas ou nas hastes. Seu ciclo evolutivo é composto por ovo, larva e pulpa. A larva é denominada de lagarta e passa por cinco instares, mede cerca de $30-50 \mathrm{~mm}$ de comprimento por $4-5 \mathrm{~mm}$ de largura quando completamente desenvolvida. O período larval é em média de 5 a 7 semanas. O período de pupa tem uma duração média de 13 a 16 dias. O adulto é uma mariposa de 35 a $45 \mathrm{~mm}$ de envergadura de cor pardo-palha, com asas anteriores de mesma cor e asas posteriores brancas. O abdômen é pardo claro, trazendo algumas escamas brancas que formam manchas brancas no dorso, junto ao tórax (MENEZES, 2003).

Após a eclosão dos ovos as lagartas perfuram a haste escavando galerias, provocando a hipertrofia da rama, caracterizada por uma distorção e um alargamento considerável. Quando as raízes tuberosas são formadas, a larva pode alcançá-las e escavar galerias em seu interior, podendo às vezes ser feitas próxima à superfície da casca, mas que raramente se rompe. Essas galerias geralmente estão sempre limpas, livres de excrementos e podridão, diferindo daquelas feitas pela broca da raiz (MENEZES, 2003).

Portanto, o estágio de lagarta é o responsável pelos danos a essa planta, cujos sintomas da infestação são observados, conforme anteriormente descritos, principalmente na haste e ocasionalmente nas raízes tuberosas. Outro sinal da presença do inseto é a morte repentina das hastes da batata-doce. Quando não morrem, elas tendem a murchar nas horas mais quente do dia, culminando por secarem completamente (MENEZES, 2003).

Existem poucos estudos disponíveis sobre a eficiência de inseticidas no controle das pragas-chave da batata-doce. O controle químico tem se mostrado inviável, principalmente 
devido ao elevado custo e inexistência de produtos registrados para a cultura. Assim, o uso de cultivares resistentes, controle biológico, dentre outras medidas tornaram-se objeto de estudo como métodos de controle para essas pragas (MASSAROTO, 2010).

\section{6 - Medidas de controle}

Em sistemas de produção de pequena escala é raro observar danos severos causados por pragas e doenças, isso ocorre devido ao maior isolamento entre plantios, maior rotação de área de cultivo e à menor população de insetos e patógenos. Quanto mais intensivo é o sistema de produção, maior a oportunidade de ataque de pragas e doenças, devendo ser maior o cuidado para evitar a ocorrência de danos econômicos (KALKMANN, 2011).

A batata-doce é uma hortaliça muito importante e popular, cujo plantio se expandiu por várias regiões do Brasil, intensificando seu cultivo, o que resultou em graves problemas fitossanitários (PINHEIRO, 2012). Os insetos de solo e patógenos são responsáveis por danos diretos, afetando a qualidade e a conservação das raízes de batata-doce, prejudicando a produção principalmente nos aspectos de comercialização (AZEVEDO, 2000).

Diversas práticas culturais são recomendadas para controle dos insetos de solo, como: escolha da época de plantio, para que o período inicial do ciclo da cultura não coincida com altos níveis populacionais da praga; plantio de material de propagação sadio, conduzidas em viveiro ou em cultivo de meristemas; eliminação de restos culturais; rotação de culturas; plantio de variedades resistentes; uso de inseticidas, quando possível; plantio em áreas sem histórico de ocorrência de pragas severas; execução de plantios isolados para evitar contaminação entre cultivos; fazer revolvimento do solo antes do plantio para promover o esmagamento e exposição de larvas, destruindo abrigos e fontes de alimentos; reformar os canteiros minimizando a ocorrência de rachaduras laterais do solo o que reduz o acesso dos insetos as raízes; rotação com culturas não hospedeiras; adubação, correção do solo e capinas promovendo o rápido desenvolvimento da cultura; irrigação adequada; destruição das soqueiras, pois restos culturais podem ser fontes de inóculos; e por fim a antecipação da colheita quando houver perspectivas de danos significativos (FRANÇA \& RITSCHEL, 2002; SILVA et al., 2008; MENEZES, 2003).

É recomendável o uso do manejo integrado de pragas (MIP) para obter maior eficiência no controle das pragas-chaves da cultura da batata-doce. No controle dos insetos também podem ser usados métodos biológicos envolvendo o uso de diversos inimigos naturais identificados, como parasitoides e predadores, porém ocorre grande dificuldade em encontrar espécies capazes de localizar e atacar eficientemente os insetos protegidos no solo 
(MENEZES, 2003; SILVA et al., 2008). Wanderley et al. (2004), afirmaram que pode-se aliar variedades resistentes e controle biológico dentro de uma estratégia de manejo integrado de pragas.

A amostragem de solo e tubérculos infectados é essencial para se estabelecer medidas de manejo necessárias e aplicáveis durante o cultivo da batata-doce. Essas medidas são planejadas visando reduzir a população inicial das pragas e nematoides ou evitar que novas áreas sejam contaminadas (PINHEIRO, 2012).

As práticas de manejo mais adotadas para os fitonematoides na produção de batatadoce incluem a combinação dos seguintes métodos: conhecimento do histórico da área, evitando aquelas que tenham sido cultivadas com plantas suscetíveis a nematoides; rotação de cultura com cultivares resistentes, plantas não hospedeiras e plantas antagônicas; uso de ramas ou mudas não infectadas e formação de viveiros a partir de material sadio; eliminação de restos culturais e das soqueiras; uso de cultivares resistentes, dentre outras também utilizadas no controle de insetos (PINHEIRO, 2012; SILVA et al., 2008).

Plantios sucessivos em um mesmo local aumentam a ocorrência de pragas e doenças e provocam redução da produtividade. Por isso, a rotação de culturas é uma prática agrícola sempre recomendada em programas de manejo e conservação do solo e em controle integrado de pragas, doenças e plantas daninhas. Durante dois ou três anos não se deve cultivar a mesma área com batata-doce, devendo-se executar a rotação de culturas (SILVA et al., 2008).

$\mathrm{Na}$ cultura da batata-doce o controle fitossanitário geralmente é difícil, pois os patógenos e os insetos localizados no solo não são facilmente atingidos pelos agrotóxicos. A aplicação de qualquer produto químico no solo tem implicações sérias, dos pontos de vista toxicológico, ambiental e econômico, além de provocar desequilíbrio biológico pela exterminação de inimigos naturais e microrganismos antagônicos, favorecendo a reinfestação do solo em condições mais favoráveis aos agentes patogênicos (SILVA et al., 2008).

Além disso, não há atualmente nenhum produto (nematicida, inseticida, fungicida ou herbicida) registrado para essa cultura, o que pode levar o produtor a aplicar os produtos indevidamente, gerando riscos a sua saúde, à saúde do consumidor e à própria sanidade e vigor da cultura (KALKMANN, 2011).

Segundo Freitas et al. (2001), o controle químico pode ser utilizado com a ressalva de que é considerado eficiente somente quando for empregado em conjunto com outras medidas, podendo se tornar, caso contrário, ineficiente e antieconômico, sendo que em sistemas de produção orgânica ou agroecológica, o uso de inseticidas não é permitido. 
O melhor controle é o preventivo, sendo que sua base é a obtenção de plantas sadias. Segundo Dusi e Silva (1991), para utilização de material de propagação sadio deve-se conduzir plantas matrizes em viveiro, obtidas por meio de cultura de meristema e reproduzidas em ambiente protegido, garantindo-se a ausência de vírus e de todos os inóculos de patógenos e pragas. Caso este material não seja disponível, as ramas-semente devem ser retiradas de uma cultura sadia e bem conduzida (SILVA et al., 2008).

Após a colheita, as ramas, pequenas batatas e pedaços de raiz podem originar novas plantas, constituindo a soqueira, que geralmente hospeda pragas e patógenos que contaminam cultivos posteriores. O uso de herbicida sistêmico, embora oneroso, é o processo mais eficaz e deve ser feito no estádio de desenvolvimento correspondente ao início da tuberização das raízes da soqueira, ou seja, cerca de um mês, após a colheita. Após 3 a 4 semanas da aplicação do herbicida, o terreno deve ser arado e gradeado, procedendo-se à catação manual das batatas e brotações remanescentes (SILVA et al., 2008).

A utilização de cultivares resistentes contribui para melhorias no rendimento da cultura e na qualidade das raízes, pois são genótipos de batata-doce mais adaptados e resistentes ao ataque de nematoides e insetos de solo, sendo uma alternativa de controle mais eficaz. (SILVA et al., 2008).

Várias são as medidas indicadas para o controle de pragas e doenças, sendo o manejo preventivo o mais recomendado, porém os métodos quando usados em conjunto são mais eficientes do que quando aplicados isoladamente.

\section{7 - Mecanismos de resistência}

A batata-doce foi uma hortaliça muito cultivada em períodos quando ainda não se utilizavam agrotóxicos intensivamente, sendo esse fato um indício de sua resistência natural a pragas e doenças. Presume-se que a resistência da cultura esteja localizada na pele das raízes. Woolfe, (1992), afirma que essa resistência foi comprovada após ter sido descoberta a presença de fitoalexinas, extraídas pela primeira vez nesta planta, as quais funcionavam como antibióticos naturais. Quando as raízes são danificadas por fungos patogênicos, tais como Ceratocystis fimbriata ou Fusarium solani, ou então invadidas por brocas como Euscepes postfasciatus, a planta reage ao ataque produzindo uma variedade de sesquiterpenos que tornam o tecido vegetal amargo e com odor forte (SCHNEIDER et al., 1984; KALKMANN, 2011). 
De acordo com Huang (1985) as fitoalexinas são compostos de baixo peso molecular e antimicrobianos, sendo sintetizadas e acumuladas nas plantas em geral depois da exposição aos microorganismos, podendo ter papel relevante no mecanismo de resistência da planta. Embora não haja evidências que comprove que tais compostos sejam o fator primário na resistência ao parasita, a maioria das fitoalexinas possuem uma forte atividade microbiana. Essas substâncias têm diversas estruturas químicas, mas a maioria delas são isoflavonóides, poliacetilenos, terpenóides e esteróides.

A batata-doce possui resistência natural a pragas e doenças, exercendo o efeito de antibiose por meio da produção de fitoalexinas, possuindo grande capacidade de compensação, cicatrizando feridas, repondo fartamente as áreas atacadas e produzindo tecido vascular secundário quando a medula da haste é danificada. Por isso, embora seja hospedeira de diversas espécies fitófagas, são poucas as pragas e doenças capazes de causar danos severos. Além disso, boa parte destes danos é apenas de efeito cosmético, por serem ferimentos ou galerias superficiais, que não reduzem a proporção de aproveitamento do produto. A maioria dos agentes causadores de patologias provocam danos durante as fases de formação de mudas (viveiro) e de pós-colheita da cultura da batata-doce, fases nas quais são baixas as concentrações dessas substâncias de ação imunológica (SILVA et al., 2008).

O Projeto Internacional de Meloidogyne apontou que um grande número de plantas contém compostos tóxicos aos nematoides das galhas. Os compostos fenólicos envolvidos na formação de necroses e lesões têm sido frequentemente sugeridos como compostos responsáveis pela resistência à doença (SASSER et al., 1983).

A maioria das plantas é imune aos nematoides. A imunidade é definida como a condição da planta que leva a incapacidade de o nematoide se desenvolver e reproduzir no interior de seus tecidos, frequentemente por mecanismo de bloqueio que se manifesta já no início da penetração, inibindo-a, não sendo essas plantas danificadas pelos nematoides (SILVA, 2011).

A palavra resistência é um termo usado para descrever a resposta da interação entre a planta e o nematoide. As cultivares resistentes são constituídas de plantas que têm um fenótipo diferente de pelo menos uma outra planta da espécie e geralmente diferem das cultivares comumente cultivadas. Em muitos casos, a resistência é uma resposta extrema da eficiência do hospedeiro demonstrada pelo genótipo da planta (COOK \& STARR, 2006).

A resistência de plantas a patógenos consiste na habilidade da planta em inibir ou impedir a reprodução do parasita. Há dois tipos de resistência: pré-infectiva e pós-infectiva. A 
resistência pré-infectiva é uma resistência passiva, ocorrendo antes da penetração pelo nematoide e está associado à produção de exudados radiculares que repelem o J2 ou são tóxicos a ele ou a não penetração devido a condições físicas adversas das raízes. A resistência pós-infectiva é chamada de resistência ativa, determinada pela interação entre parasita e hospedeiro, muito comum e se manifesta após a penetração do J2 nos tecidos da planta. A resistência pode ser de baixa a moderada (parcial a intermediária) ou alta. A resistência parcial ou moderada permite uma reprodução baixa do patógeno. A suscetibilidade é o oposto a resistência, as plantas suscetíveis permitem o desenvolvimento normal do nematoide com uma alta reprodução (MOTA, 2010).

O fenótipo suscetível-resistente é uma mensuração da eficiência do hospedeiro. É mensurado comparando-se a reprodução do nematoide em um número de genótipos de plantas hospedeiras. Aqueles que apresentam pouca ou nenhuma reprodução são resistentes e aqueles que permitem uma reprodução considerável são suscetíveis. Essa classificação fenotípica é usada de forma adjetiva para descrever a planta, mas é derivada da interação genética entre planta e nematoide. A relevância prática disso é a possibilidade de propor que a resistência seja usada nas culturas para o controle da população de nematoides (COOK \& STARR, 2006).

A resistência também pode ser caracterizada pelo número de genes que controlam a característica, podendo ser monogênica (único gene), oligogênica (dois a três genes) ou poligênica (vários genes). A resistência também pode ser classificada como vertical (qualitativa, é específica a uma determinada raça ou biótipo do patógeno) e horizontal (quantitativa, é efetiva contra todas as variantes do patógeno). A resistência vertical é usualmente controlada por um ou alguns genes, sendo uma interação do tipo gene a gene, como comumente ocorre na interação patógeno-planta. Já a resistência horizontal é usualmente poligênica recessiva, possuindo genes de menor efeito responsáveis por ela e efeitos aditivos que conferem um nível quantitativo de resistência. Em geral, a resistência horizontal é mais durável a pressão exercida pela população de nematoides. O modo como a resistência a nematoides é herdada é importante na definição da estratégia a ser adotada para incorporá-la em cultivares comerciais (MOTA, 2010).

Outra definição importante é a de tolerância, um conceito muito importante para o desenvolvimento e uso de cultivares resistentes. A tolerância refere-se à habilidade das plantas em permitirem a invasão e reprodução do nematoide, mas não apresentarem sintomas ou danos significativos. Já a intolerância é um termo utilizado para plantas que quando 
infectadas crescem menos, morrem ou ainda reduzem drasticamente a produtividade. Existem quatro tipos de combinações envolvendo a eficiência e sensibilidade do hospedeiro: planta tolerante e resistente, planta intolerante e resistente, planta tolerante e suscetível, planta intolerante e suscetível. Os atributos de resistência e tolerância são independentes e podem ser herdados de maneira separada e diferenciada (COOK \& STARR, 2006; MOTA, 2010).

A tolerância-intolerância (ou sensibilidade) é uma mensuração da sensibilidade do hospedeiro e pode ser determinada pela avaliação do crescimento da planta na presença do nematoide, ou em termos de cultura, mensurando a perda de produtividade causada pelos nematoides. Na pratica, a sensibilidade de uma planta em particular geralmente não depende somente de seu genótipo, podendo estar relacionado também com a forma de ataque dos nematoides. Quando há grande densidade populacional dos nematoides as plantas sofrem redução no crescimento, enquanto a baixa densidade permite o crescimento satisfatório das plantas. Assim, os fatores que favorecem a atividade do nematoide tendem a aumentar a sensibilidade da planta, enquanto aqueles que favorecem o crescimento das plantas tendem a aumentar a sua tolerância (COOK \& STARR, 2006).

A reação de hipersensibilidade é também encontrada nas plantas atacadas por fitonematóides. É caracterizada como a resposta celular extrema por parte da planta, podendo levar a um alto grau de resistência à doença. A reação de hipersensibilidade resulta na morte repentina de um número limitado de células do hospedeiro que circunda os sítios de infecção. A reação é considerada como uma resposta de defesa induzida, culminando na parada do crescimento e do desenvolvimento do patógeno nos tecidos da planta. A reação é vista como uma espécie de "suicídio" de algumas poucas células da planta em prol da sobrevivência das demais, o que a torna um dos mecanismos de defesa mais importantes nas plantas (TEIXEIRA, 2011).

A resposta ocorre em função do reconhecimento da infecção, por parte do hospedeiro, como consequência da incompatibilidade entre a planta e o patógeno. Portanto, a reação de hipersensibilidade ocorre somente em interações incompatíveis envolvendo a infecção da planta pelos nematóides. A resposta da reação de hipersensibilidade aparece nas primeiras 24 horas após a inoculação, quando as células da planta e o nematoide morrem. O grau de necrose dos tecidos e o tempo de ocorrência podem diferir, mesmo em plantas de uma mesma espécie (TEIXEIRA, 2011).

Após a chegada do patógeno na planta resistente, as células infectadas rapidamente perdem o turgor, tornando-se com coloração marrom (devido à oxidação de fenóis) e morrem. 
O processo de morte celular na reação de hipersensibilidade é caracterizado pela agregação do citoplasma, pela parada dos movimentos citoplasmáticos, pela perda da permeabilidade das membranas (devido à despolarização destas, com a consequente perda de eletrólitos para o espaço extracelular), pela degeneração do núcleo e das organelas, além de aumentos acentuados da respiração e de acúmulo de compostos fenólicos e de fitoalexinas (TEIXEIRA, 2011).

Com relação aos insetos de solo pouco se sabe sobre os mecanismos de resistência envolvidos, como por exemplo, a resistência à broca-da-raiz. Cultivares de batata-doce resistentes a insetos de solo da família Chrysomelidae foram lançadas em 1975 nos EUA e o principal fator para a resistência de batata-doce a crisomelídeos de solo, como a larva-alfinete (Diabrotica spp.), pulga-do-fumo (Epitrix spp.) e a larva-arame (Conoderus spp), estava supostamente localizado na película das raízes e ainda não havia sido identificado. Este fato, porém, não impediu o desenvolvimento de cultivares resistentes. (FRANÇA \& RITSCHEL, 1997).

A resistência de plantas a insetos é caracterizada como a soma relativa de qualidades hereditárias possuídas pela planta, sobre as quais influenciam o resultado do grau de dano que o inseto causa, ou seja, é a capacidade que algumas plantas possuem de produzir melhor do que outras sob as mesmas condições de ataque de pragas. A resistência é hereditária, comprovada através de um teste de repetibilidade, isto é: toda vez que ela for comparada, a resistência se manifesta. Diferenciando-se desta há a chamada pseudo-resistência ou falsa resistência, onde fatores ambientais favorecem ou não que a planta manifeste atributos como se fosse uma planta resistente (KALKMANN, 2011).

De acordo com Ferreira (2006), a natureza da resistência de plantas aos insetos praga compreende as seguintes formas: escape, assincronia fenológica, resistência induzida e resistência. As três primeiras formas são chamadas de pseudo-resistência porque não possuem fatores genéticos de resistência e ocorrem em condições especiais, controláveis ou não.

O escape se caracteriza quando a planta não é infestada ou é pouco danificada, isso acontece quando as plantas escapam a ação do inseto-praga, devido a um simples acaso. A assincronia fenológica ocorre quando a planta passa pela sua fase de maior suscetibilidade ao ataque do inseto-praga, numa época em que a sua densidade populacional é baixa. A resistência induzida trata-se de uma manifestação temporária de resistência, em que a planta se revela menos adequada ao inseto devido a uma condição especial ou a sua interação com condições ambientais que podem, eventualmente, alterar sua fisiologia. Já a resistência trata- 
se de uma reação da planta ao ataque do inseto, revelando-se menos danificada que outra em igualdade de condições, devido a sua constituição genotípica (FERREIRA, 2006).

Ferreira (2006), diz ainda que existem três tipos de resistência de plantas aos insetospraga: não-preferência, antibiose e tolerância, podendo uma planta possuir até os três tipos de resistência simultaneamente, sendo que quanto mais tipos de resistência a planta apresentar maior será o seu grau de resistência, além de dificultar o aparecimento de raças fisiológicas do inseto-praga.

A não-preferência permite que a planta ou variedade seja menos utilizada pelo inseto que outra, em igualdade de condições, para alimentação, ovoposição ou abrigo, ou para combinações desses usos. A resistência do tipo antibiose se caracteriza pela ação adversa que a planta exerce sobre a biologia do inseto, quando o mesmo dela se alimenta normalmente, afetando o potencial de reprodução da praga. A tolerância ocorre quando a planta tem a capacidade de suportar o ataque do inseto ou regenerar tecidos atacados sem, contudo, provocar queda significativa na qualidade e quantidade de sua produção (FERREIRA, 2006).

A resistência das plantas a um determinado inseto-praga pode ser devida a uma série de causas - físicas, químicas, morfológicas, fisiológicas ou comportamentais - refletindo em última análise no efeito de um ou mais pares de genes. O comportamento fenotípico de uma variedade em relação a um determinado caráter é medido pela ação do genótipo e do ambiente e da interação entre eles $\left(\mathrm{F}=\mathrm{G}+\mathrm{E}+\mathrm{I}_{(\mathrm{GE})}\right)$. Todavia, para o caráter resistência ao insetopraga, o comportamento fenotípico da variedade depende também do genótipo do insetopraga que se integra a interação, sendo o ambiente o ponto comum da interação entre os dois distintos genótipos (FERREIRA, 2006).

A hereditariedade do hospedeiro pode ser agrupada em dois tipos: herança simples e herança complexa. Na herança simples, a resistência é condicionada por um gene maior ou poucos genes. Já na herança complexa ou poligênica, a resistência é condicionada por muitos genes tendo cada um deles um efeito pequeno, porém, os efeitos dos vários genes são acumulativos (FERREIRA, 2006).

\section{8 - Melhoramento genético}

Tem-se observado que ao longo dos anos, evoluindo de geração em geração, tem ocorrido à seleção natural de genótipos de batata-doce, os quais apresentam características agronômicas desejáveis e altamente promissoras. Entretanto, na maioria dos casos, estes materiais não expressam, na totalidade, o seu potencial produtivo, por estarem infectados com 
viroses e outras doenças degenerativas, o que resulta em perdas e depreciação do produto (EMYGDIO \& CASTRO, 2010).

A suscetibilidade à doenças e pragas, contribui para a limitação do potencial produtivo da batata-doce. Além de impedirem um desenvolvimento satisfatório das raízes, podem provocar ferimentos, rachaduras longitudinais e/ou irregularidades no formato. Deste modo, além da produtividade, a qualidade, a conservação e o aspecto comercial das raízes ficam prejudicados (FREITAS et al. (2001), SILVA et al., 2008).

No Brasil, os trabalhos de resistência varietal foram intensificados na década de 80 , quando foram estabelecidas metodologias de avaliação de germoplasmas visando resistência às pragas do solo (AZEVEDO, 2000). Coimbra et al. (2006), afirmam que a utilização de germoplasma de batata-doce resistente tem sido possível, por ser uma cultura de multiplicação essencialmente vegetativa, com alta taxa de heterozigose para todos os caracteres e larga base genética, permitindo assim, aos programas de melhoramento genético, obter novas variedades mais produtivas e resistentes a doenças e pragas.

Os trabalhos desenvolvidos com coleções de batata-doce têm por finalidade introduzir, caracterizar e conhecer a extensão da variabilidade genética de genótipos de batata-doce que possam ser utilizados em lavouras comerciais, levando em consideração a rusticidade, produtividade, adaptabilidade, assim como as características de resistência aos nematoides do gênero Meloidogyne spp. e aos insetos do solo (CASTRO et al., 2009; KALKMANN, 2011).

Esta caracterização tem a função de indicar quais os materiais poderão ser utilizados em programas de melhoramento objetivando selecionar cultivares melhorados. Visam também disponibilizar aos produtores matrizes com alta sanidade para melhorar o padrão das lavouras, considerando-se, que a eliminação de patógenos das plantas de batata-doce e a realização de avaliações em condições adequadas, possibilita a obtenção de cultivares promissoras para cultivos em larga escala. (CASTRO et al., 2009; KALKMANN, 2011).

Para o desenvolvimento de cultivares com boas características físicas de raiz, boa qualidade nutricional, resistência a pragas e doenças, e adaptação às nossas condições edafoclimáticas é necessário que sejam empregados no programa de melhoramento técnicas e estratégias que maximizem a eficiência do processo. Uma dessas ferramentas é a estimativa de parâmetros genéticos confiáveis relacionados à população em estudo, pois permite conhecer a fundo sua estrutura genética (VILELA, 2008).

Dentre os parâmetros genéticos existentes temos a herdabilidade, variância genotípica e fenotípica, coeficientes de variação genotípico e fenotípico, entre outros, que permitem a 
obtenção de informações sobre a natureza da ação dos genes envolvidos no controle dos caracteres (VILELA, 2013).

A herdabilidade mede o grau de correspondência entre a variância fenotípica e variância genética, ou seja, reflete a proporção da variação fenotípica que pode ser herdada permitindo a seleção dos genótipos que se destacaram na população e a escolha do melhor método de melhoramento a ser aplicado em cada caso. Valores altos deste parâmetro indicam que métodos de seleção simples, como seleção massal, podem levar a ganhos consideráveis, considerando que o ambiente exerce pouca influência (VILELA, 2008).

O coeficiente de herdabilidade pode ser expresso no sentido restrito e amplo, sendo que no sentido amplo expressa a proporção de variância genética em relação à variância fenotípica total observada. A herdabilidade no sentido restrito tem a finalidade de orientar o geneticista sobre a quantidade relativa da variância genética, sou seja, variância genética aditiva, que é utilizada no melhoramento. No caso da batata-doce, a herdabilidade no sentido amplo é importante porque os efeitos de epistasia e dominância são mantidos pela propagação vegetativa (VENCOVSKY \& BARRIGA, 1992; GONÇALVES NETO, 2010).

Os valores mínimo e máximo para a herdabilidade são 0 e 1 , sendo o valor 0 um indicativo de que não há variação nos valores melhoradores. Qualquer tentativa de seleção com base nos fenótipos só poderá dar resultados, isto é, produzir respostas, se a herdabilidade não for nula. Segundo Bourdon (1997), em geral considera-se que valores de herdabilidade de 0,01 a 0,20 são baixas (a característica é pouco herdável), entre 0,20 e 0,40 moderadas (a característica é moderadamente herdável) e acima de 0,40 são altas (a característica é bastante herdável) (KALKMANN, 2011).

Além disso, em um programa de melhoramento de batata-doce é fundamental conhecer a magnitude da variação genética e os coeficientes de herdabilidade, visto que a variação genética é a matéria-prima do melhoramento e sem variação genética nada pode ser feito em termos de seleção (MIRANDA et al., 1995). Para que a seleção de indivíduos superiores geneticamente seja eficiente, é necessário que haja variação fenotípica suficiente na população original e os valores de herdabilidade sejam altos, ou seja, a variação genotípica deve expressar o resultado da ação dos genes (BUENO, 2006). O conhecimento do controle genético de caracteres sob seleção e de suas correlações também é indispensável tanto para aumentar as chances de êxito de um programa de melhoramento quanto possibilitar reduções de tempo, custo e esforços dispendidos (MIRANDA et al., 1995). 
Assim, como o uso de nematicidas é considerado antieconômico como medida de controle dos nematoides, o uso de inseticidas para controlar os insetos-praga de solo também é uma medida de elevado custo e baixa eficiência (MIRANDA et al., 1995). Entretanto, a utilização de germoplasma resistente tem sido possível, constituindo-se numa importante alternativa de controle dos nematoides e insetos-praga (AZEVEDO et al., 2000).

Os resultados de pesquisa da Embrapa Clima Temperado, indicam que o germoplasma de batata-doce existente na Região Sul do Brasil, apresenta alto potencial de seleção de materiais genéticos com elevado potencial de cultivo, reduzindo tempo e investimentos no desenvolvimento de pesquisas básicas (CASTRO, 2009). Segundo Wanderley et al. (2004), trabalhos com resistência de cultivares de batata-doce a nematoides e insetos de solo têm sido desenvolvidos nas últimas décadas no Brasil, entretanto, uma grande diversidade de cultivares ainda necessita ser avaliada.

Na batata-doce o melhoramento é utilizado com intuito de aumentar a frequência dos alelos favoráveis ou a exploração da heterose. Dentre as técnicas de melhoramento de populações existentes, na batata-doce, geralmente é realizado o policruzamento seguido por ciclos de seleção recorrente (PEIXOTO, 2009).

O policruzamento ("policross") é um método de cruzamento que favorece a recombinação do material genético. Cada material é circundado pelo maior número possível de materiais diferentes dele, isto favorece o cruzamento em alógamas e maximiza a probabilidade de haver novas combinações genéticas. Na batata-doce pode-se viabilizar o policruzamento realizando em seguida a seleção recorrente (PEIXOTO, 2009).

Segundo Ferreira (2006), esse método consiste na seleção de genótipos numa população heterogênea, obtenção de meios-irmãos dos genótipos selecionados, avaliação dessas progênies em ensaios de campo e recombinação dos melhores genótipos que foram selecionados em função do comportamento de suas progênies, para formar a população melhorada, denominada de sintético, repetindo-se o processo. Nesse método, cada ciclo envolve três etapas distintas:

a) obtenção das progênies de meios-irmãos dos genótipos selecionados;

b) avaliação das progênies de meios-irmãos em ensaio de produção;

c) recombinação dos melhores genótipos.

A seleção recorrente é uma técnica de melhoramento de populações que tem por objetivo a concentração de alelos favoráveis, mantendo a variabilidade genética da população. As populações melhoradas, por meio da seleção recorrente, podem ser utilizadas diretamente 
como variedades de polinização aberta ou então para obtenção de linhagens endogâmicas utilizadas na produção de híbridos (BESPALHOK et al., 2007).

Esse método consiste numa seleção contínua que vai sendo repetida após cada ciclo de seleção. Em outras palavras, consiste na re-seleção, geração após geração, com intercruzamento entre os tipos selecionados, visando-se promover a recombinação gênica. Os genótipos desejáveis, ou as suas progênies autofecundadas, são selecionados e cruzados entre si, em todas as combinações, a fim de produzir populações para nova seleção. Esses procedimentos ajudam a manter a frequência dos materiais selecionados. Ciclos recorrentes (adicionais) de seleção podem ser conduzidos enquanto ganhos genéticos satisfatórios são obtidos (FERREIRA, 2006).

O uso da seleção recorrente em batata-doce apresenta as seguintes vantagens: manutenção de alta variabilidade genética enquanto aumenta a média da população (sempre se seleciona material com média melhor em relação à geração anterior, e a frequente recombinação mantém a alta variabilidade genética); grande facilidade de obtenção de semente botânica (no policruzamento o inseto faz polinização em grande quantidade do material pré-selecionado para florescimento precoce e há produção de muita semente botânica); grande facilidade de se introduzir novos genótipos neste programa de seleção recorrente (PEIXOTO, 2009). 


\section{REFERÊNCIAS BIBLIOGRÁFICAS}

AZEVEDO, S. M.; FREITAS, J. A.; MALUF, W. R.; SILVEIRA, M. A. Desempenho de clones e métodos de plantio de batata-doce. Revista Acta Scientiarum, Maringá, v. 22, n. 4, 901-905p., 2000.

BESPALHOK F., J.C.; GUERRA, E.P.; OLIVEIRA, R. Uso e conservação do germoplasma. In: BESPALHOK F., J.C.; GUERRA, E.P.; OLIVEIRA, R. Melhoramento de Plantas. Disponível em: <http://www.bespa.agrarias.ufpr.br/paginas/conteudo.htm> (2007). Acesso em: 06 de junho de 2014.

BOURDON, R. M. Understanding animal breeding. New Jersey: Prentice Hall, p.523, 1997.

BRUNE, S.; SILVA, J. B. C.; FREITAS, R. A. Novas técnicas de multiplicação de ramas de batata-doce. Embrapa Hortaliças. Brasília, Circular técnica 39, p. 8, 2005.

BUENO, L. C. de S.; MENDES, A. N.; CARVALHO, S. P. de. Melhoramento de plantas: princípios e procedimentos. 2. ed. Lavras: UFLA, 2006. 319 p.

CARMONA, P. O. Caracterização morfoagronômica, físico-química e tolerância ao nematoide-das-galhas de genótipos de batata-doce avaliados no Distrito Federal. Tese (Doutorado em Agronomia), Faculdade de Agronomia e Medicina Veterinária - FAV, Universidade de Brasília - UnB, Brasília, 227 f.: il., 2015.

CARVALHO, C.; KIST, B. B.; POLL, H. Anuário Brasileiro de Hortaliças. Rio Grande do Sul, Santa Cruz do Sul: Editora Gazeta Santa Cruz, 88 p.: il., 2013.

CASTRO, L. A. S. de; TREPTOW, R. de O.; CAMPOS, A. D.; CHOER, E.; THÜRMER , L. Acessos de batata-doce do banco ativo de germoplasma da Embrapa Clima Temperado recomendados para mesa e processamento industrial. Embrapa Clima Temperado. Pelotas (RS), documentos 289, p. 26, 2009.

COIMBRA, K. G.; Ribeiro, N. L. S.; Uesugi, C. H.; PEIXOTO, J. R. Reação de clones de batata-doce (Ipomoea batatas (L.) Lamarck) aos nematoides de galhas do gênero Meloidogyne. In: Congresso Brasileiro de Olericultura 46, 2006, Goiânia. Revista Horticultura Brasileira, v. 25, Suplemento, Brasília, 2006.

COOK, R. \& STARR, J. L. Plant Nematology - Chapter 15: Resistant Cultivars. CCAB International, 2006.

DUSI, A. N; SILVA, J. B.C. Produção de ramas de batata-doce livre de vírus. Horticultura Brasileira, Brasília, DF, v. 9, p. 37, (resumo 48), 1991.

EMYGDIO, B. M \& CASTRO, L. A. S. A batata-doce para produção de biocombustível. Página Rural. 2010. Disponível em: <http://www.paginarural.com.br/artigos_detalhes.php?id=2007\&impr\%20...> Acesso em: 03 de junho de 2014. 
FAO - FOOD AND AGRICULTURE ORGANIZATION OF THE UNITED NATIONS. Dados agrícolas de 2008. Disponível em: 〈http://www.fao.org/>. Acesso em: 30 de maio 2014.

FERREIRA, P. V. Coleção Melhoramento de Plantas. Métodos de Melhoramento. Maceió: EDUFAL, v. 5, il., 2006.

FOLQUER, F. La batata (Camote). Estudio de la planta y su producción comercial. Editorial Hemisferio Sur., 82p.,1978.

FORTES, C. R. Avaliação de genótipos de batata-doce [Ipomoea batatas (L.) Lam.], em diferentes tipos de cultivos, na região de tabuleiros costeiros do estado de Alagoas. Dissertação (Mestrado em Agronomia: Produção vegetal), Centro de Ciências Agrárias, Universidade Federal de Alagoas, Rio Largo, 103 f.: il., tabs., grafs, 2010.

FRANÇA, F. H.; RITSCHEL, P.S.; Avaliação de acessos de batata-doce para resistência à broca da raiz crisomelídeos e elaterídeos. Horticultura Brasileira, v.20, n.1, p. 79-85. Brasília, 2002.

FRANÇA, F.H. \& RITSCHEL, P.S. Caracterização de acessos de batata-doce através dos danos causados nas raízes por crisomelídeos e pela broca da raiz. Pesquisa em andamento, $\mathrm{n}^{\mathrm{o}}$ 2, 1997. Disponível em: HTTP://www.cnph.embrapa.br/pa/pa02.html. Consultado em: 4 de junho de 2014.

FREITAS, J. A.; SANTOS, G. C.; SOUZA, V. S.; AZEVEDO, S. M. Resistência de clones de batata-doce, Ipomoea batatas L., aos nematoides causadores de galhas. Revista Acta Scientiarum, Maringá, v. 23, n. 5, 1257-1261p., 2001.

GONÇALVES NETO, A.C. Aptidões para consumo humano, produção de etanol e alimentação animal em clones de batata-doce. 2010. 77p. Tese (Doutorado) - Universidade Federal de Lavras, Lavras - MG.

GUEDES, A.N.; LEITÃO, A.M.; CÉSAR, J. Batata-doce: nova alternativa agrícola para o estado do Amazonas. Manaus, Embrapa - UEPAE Manaus, Comunicado Técnico 7, 7 p., 1980.

HUANG, J.S. Mechanisms of resistance to root-knot nematodes. In: SASSER, J.N.; CARTER,L.C. (eds). An advanced treatise on Meloidyne. Raleigh: International Meloidogyne project, v.1, cap.14, p.165-174, 1985.

HUNT, D. H. \& HANDOO, Z. A. Root-knot nematodes. Meloidogyne Species - a Chapter 3: Taxonomy, Identification and Principal Species. CCAB International, 2009.

IBGE - INSTITUTO BRASILEIRO DE GEOGRAFIA E ESTATÍSTICA. Produção Agrícola Municipal. Culturas temporárias e permanentes. Áreas plantada e colhida, quantidade produzida, rendimento médio e valor da produção dos principais produtos das lavouras temporárias, segundo as Grandes Regiões e Unidades da Federação produtoras. Rio de Janeiro, v. 39, p. 1-101, 2012. Disponível em: <http://www.ibge.gov.br/home/estatistica/pesquisas/pesquisa_resultados.php?id_pesquisa=4. Acesso em: 29 de maio de 2014. 
KALKMANN, D. C. Produtividade, qualidade de raiz, resistência aos insetos de solo e aos nematoides de galhas, e estimativas de parâmetros genéticos em clones de batatadoce cultivados no Distrito Federal. Dissertação (Mestrado em Agronomia), Faculdade de Agronomia e Medicina Veterinária - FAV, Universidade de Brasília - UnB, Brasília, 2011. $144 \mathrm{p}$.

LEONEL, M. \& CEREDA, M.P. Caracterização físico-química de algumas tuberosas amiláceas. Ciência e Tecnologia de Alimentos, Campinas, 22(1): 65-69, jan.-abr. 2002.

MANO, H.; OGASAWARA, F.; SATO, K.; HIGO, H. \& MINOBE, Y. Isolation of a Regulatory Gene of Anthocyanin Biosynthesis in Tuberous Roots of Purple-Fleshed Sweet Potato. Plant Physiology, v. 143, p. 1252-1268, 2007. Disponível em: <http://www.ncbi.nlm.nih.gov/pmc/articles/PMC1820918/> Acesso em: 15 de maio de 2014.

MASSAROTO, J. A. Características agronômica e produção de silagem de clones de batata-doce. Tese (Doutorado). Universidade Federal de Lavras - UFLA, Lavras, 73 p.:il 2010.

MATTOS, V. S. Variabilidade genética e agressividade a soja [Glycine max (L.) Merrill] de populações de Meloidogyne spp. do cerrado e de áreas de cultivo. Dissertação (Mestrado em Agronomia), Programa de Pós-graduação em Fitopatologia, Universidade de Brasília - UnB, Brasília, 2013. 82 il.

MELO, W. F.; SILVA, J. B. C.; GOMES, L. M.; MOITA, A, W.; AMARO, G. B.; FERNADES, F. R.; NUTTI, M. R.; DUSI, A. N. Biofortificação no Brasil (Biofort): Avaliação preliminar de clones de batata-doce ricos em betacaroteno em duas épocas de plantio. IV Reunião de Biofortificação. Teresina, Piauí, Brasil, 2011.

MENEZES, E. L. A. A Broca da Batata-doce (Euscepes postfasciatus): Descrição, Bionomia e Controle. Embrapa Agrobiologia. Seropédica (RJ), Circular técnica 6, p. 12, out. 2002.

MENEZES, E. L. A. Broca do coleto da batata-doce (Megastes spp.): Descrição, Bionomia e Controle. Embrapa Agrobiologia. Seropédica (RJ), Circular técnica 7, p. 12, nov. 2003.

MIRANDA, J.E.C.; FRANÇA, F.H.; CARRIJO, O.A.; SOUZA, A.F.; PEREIRA, W.; LOPES, C.A.; SILVA, J.B.C. A cultura da Batata-doce. Embrapa - CNPH, Brasília: Coleção Plantar; $1^{\text {a }}$ ed.; 94 p.; 1995.

MOENS, M.; PERRY, R. N.; STARR, J. L. Root-knot nematodes. Chapter 1: Meloidogyne Species - a Diverse Group of Novel and Important Plant Parasites. CCAB International, 2009.

MOTA, F. C. Análise de fontes de resistência do algodoeiro a Meloidogyne incognita raça 3 e caracterização histopatológica da interação planta-nematoide. Dissertação (Mestrado em Agronomia), Programa de Pós-graduação em Fitopatologia, Universidade de Brasília UnB, Brasília, 2010. 76 il.

NÓBREGA, D. S. Reação de clones de batata-doce aos nematóides de galhas do gênero Meloidogyne sp. Trabalho de Conclusão de Curso em Agronomia - Universidade de Brasília, Faculdade de Agronomia e Medicina Veterinária. Brasília, 2011. 30 p.: il. 
NUNES, M. U. C. ; CRUZ, D. P. C. ; FORTUNA, A. Tecnologia para produção de farinha de batata-doce: Novo produto para os agricultores familiares. Embrapa Tabuleiros costeiros. Circular técnica 65. Aracaju, dezembro, 2012.

OLIVEIRA, A. C. B.; SEDIYAMA, M. A. N.; SEDIYAMA, T.; FINGER, F. L.; CRUZ, C. D. Variabilidade genética em batata-doce com base em marcadores isoenzimáticos. Revista Horticultura Brasileira, Brasília, v. 20, n. 4, 576-582p., 2002.

PEIXOTO, J. R. Melhoramento genético da batata-doce [Ipomoea batatas (L.) Lamarck] visando a produtividade, qualidade de raiz e resistência aos insetos de solo e aos nematoides de galhas do gênero Meloidogyne spp. Projeto de pesquisa. Faculdade de Agronomia e Medicina Veterinária - FAV. Universidade de Brasília - UnB. Brasília, 2009.

PEREIRA, C.R.; SANTOS, M.A.; RIBEIRO, H.U.; BARRA, P.B.; LOURO, F.S.C.; QUEIROGA, R.C.F. Composição química dos resíduos de cultivares de batata-doce submetida a diferentes idades de colheita. In: CONGRESSO BRASILEIRO DE OLERICULTURA, 43. Resumos... Recife: SOB (CD-ROM), 2003.

PERES, A. C. J. Seleção de genótipos de coffea arabica $\mathbf{L}$. com resistência a Meloidogyne spp. em condições de casa de vegetação e a campo. Dissertação de Mestrado - Faculdade de Agronomia e Medicina Veterinária - FAV, Universidade de Brasília - UnB, Brasília, 94 p.: il., 2013.

PINHEIRO, J. B.; RODRIGUES, C. S.; CARVAlHO, A. D. F.; PEREIRA, R. B. Nematoides na cultura da batata-doce. Embrapa hortaliças. Brasília, Circular técnica 105, p. 9, 2012.

RABELLO, F. R. Reação de clones de batata-doce [Ipomoea batatas (L.) Lamarck] à Meloidogyne spp. Trabalho de conclusão de curso (Graduação em Agronomia), Faculdade de Agronomia e Medicina Veterinária - FAV, Universidade de Brasília - UnB, Brasília, p. 46, 2010.

RAMALHO, R.A.; FLORES, H.; SAUNDERS, C. Hipovitaminose A no Brasil: um problema de saúde pública. Revista de Saúde Pública, v. 34, n. 1, p. 56-63, 2002.

RICCI, M. S. F; GUERRA, J. G. M.; ALMEIDA, F. F. D.; RIBEIRO, R. L. D. R.; AGUIAR, L. A.; COCHETO JUNIOR, D. G. Incidência de broca-da-raiz (Euscepes postfasciatus) em cultivares de batata-doce cultivadas em sistema orgânico. Embrapa Agrobiologia. Seropédica (RJ), Comunicado técnico 142, p. 3, 2011.

RITSCHEL, P.S.; HUAMÁN, Z.; LOPES, C.A.; MENÊZES, J.E.; TORRES, A.C. Catálogo de germoplasma de batata-doce $\mathbf{I}$ : coleção mantida pela Embrapa Hortaliças. Embrapa Hortaliças. Documentos, 23, 47p., 1999.

SASSER, J.N., EISENBACK, J.D., CARTER, C.C. AND TRIANTAPHYLLOU, A.C. The International Meloidogyne Project - its goals and accomplishments. Annual Review of Phytopathology 21, 271-288, 1983. 
SERA, G. H.; SERA, T.; ITO, D.S.; MATA, J. S. DA; DOI, D. S.; AZEVEDO, J.A. DE; RIBEIRO FILHO, C. Progênies de Coffea arabica cv IPR-100 resistentes ao nematoide Meloidogyne paranaensis. Bragantia, Campinas, v.66, n.1, p.43-49, 2007.

SCHNEIDER, J. A.; LEE, J.; NAYA, Y.; NAKANISHI, K.; OBA, K.; URITANI, I. The fate of the phytoalexin ipomeamarone: furanoterpenes and butenolides from Ceratocystis fimbriata infected sweet potatoes. Phytochemistry, v. 23, n. 4, 759-764p., 1984.

SCHRAMMEL, P. Desempenho agronômico de clones de batata-doce em condições de campo. Dissertação (Graduação em Agronomia), Faculdade de Agronomia e Medicina Veterinária - FAV, Universidade de Brasília - UnB, Brasília, 34 p., 2011.

SILVA, J. B. C.; LOPES, C. A.; MAGAlHÃES, J. S. Cultivo da batata-doce. Brasília: EMBRAPA-CNPH, Sistemas de Produção 6, ISSN 1678-880X - Versão Eletrônica, Junho 2008.

SILVA, J. B. C.; MELO, W. F. de; BUSO, J. A.; NUTTI, M. R.; CARVALHO, P. G. B. de; CARVALHO, J. L. V. de; NUNES, M. U. C.; FARIAS, A. Beauregard: cultivar testada e indicada de batata-doce. Brasília, DF: Embrapa Hortaliças, 2010.

SILVA, J. F. V. Relações parasito-hospedeiro nas meloidoginoses da soja. Capítulo 4: Resistencia genética de soja a nematoides do gênero Meloidogyne. Ministério da Agricultura Pecuária e Abastecimento. Embrapa Soja. Londrina - PR, 2011.

SOUZA, F. R.; SILVEIRA, M. A ; TAVARES, I. B; SOUZA, A. F. B. C. Quantificação de diferentes concentrações enzimáticas de alfa.-amilase e amiloglucosidase em fermentação de meio hidrolisado para produção de álcool a partir da cultura de batata-doce. Anais... I Congresso Científico, Universidade Federal do Tocantins, Palmas, 2005.

SCHNEIDER, J. A.; LEE, J.; NAYA, Y.; NAKANISHI, K.; OBA, K.; URITANI, I. The fate of the phytoalexin ipomeamarone: furanoterpenes and butenolides from Ceratocystis fimbriata infected sweet potatoes. Phytochemistry, v.23, n.4, p.759-764, 1984.

TEIXEIRA, R. A. Mecanismos de resistência a fitodoenças. Revisão Bibliográfica Seminários. Programa de Pós-Graduação em Genética e Melhoramento de Plantas, da Universidade Federal de Goiás - UFG. Goiânia, 2011. 25p.

VENCOVSKY, R. \& BARRIGA, P. Genética Biométrica no melhoramento. Ribeirão Preto: SBG. 496p. 1992.

VILELA, M. S. Estimativas de parâmetros genéticos para caracteres de cenoura em sistemas de cultivo agroecológico. Dissertação (Mestrado em Ciências Agrárias), Faculdade de Agronomia e Medicina Veterinária - FAV, Universidade de Brasília - UnB, Brasília, 68 p. : il., 2008.

VILELA, M. S. Avaliação de progênies de maracujazeiro-azedo quanto ao desempenho agronômico, resistência à doença e diversidade genética. Tese (Doutorado em Agronomia), Faculdade de Agronomia e Medicina Veterinária - FAV, Universidade de Brasília - UnB, Brasília, 68 p. : il., 2013. 
WANDERLEY, P. A.; BOIÇA JR., A. L.; WANDERLEY, M. J. A. Resistência de cultivares de batata-doce a Euscepes postfasciatus Fairmaire (Coleoptera: Curculionidae). Neotropical Entomology, v.33, n.3, p.371-377. 2004.

WOOLFE, J. A. Sweet potato: an untapped food resource. Cambridge University Press, p. $188,1992$. 


\section{CAPÍTULO I}

PRODUTIVIDADE E RESISTÊNCIA DE CLONES DE BATATA-DOCE AOS INSETOS DE SOLO 


\section{PRODUTIVIDADE E RESISTENNCIA DE CLONES DE BATATA-DOCE AOS INSETOS DE SOLO}

\section{RESUMO}

A batata-doce é considerada uma cultura rústica e com elevado potencial de produção, apresenta grande resistência a pragas, pouca resposta à aplicação de fertilizantes e cresce em solos pobres e degradados. Ainda sim, a cultura é suscetível a um grande número de pragas e doenças. A busca e a caracterização de fontes de resistência a pragas e doenças tem sido alvo de muitas pesquisas visando selecionar e recomendar cultivares de batata-doce para diferentes regiões do país. O objetivo deste trabalho foi avaliar 10 genótipos de batata-doce quanto à produtividade e a resistência a insetos de solo nas condições do Cerrado do Distrito Federal. Os genótipos avaliados foram oriundos do Banco de Germoplasma da Embrapa Hortaliças (CNPH) e o ensaio foi conduzido na Fazenda Água Limpa da Universidade de Brasília (UnB). O ensaio foi instalado utilizando-se o delineamento experimental de blocos casualizados com 10 tratamentos, 4 repetições e 10 plantas de batata-doce/parcela. Foram avaliados 10 genótipos: Princesa (CNPH 3), Brazlândia Rosada (CNPH 9), Santa Sofia (CNPH 17), CNPH 29, Georgia Improved (CNPH 31), Balão (CNPH 46), CNPH 53, Batata Africana 1 (CNPH 61), Batata Correntina $n^{\circ} 24$ (CNPH 66) e CNPH 71. As características avaliadas foram: número de furos; incidência de danos; grau de resistência; formato e comprimento de raiz; espessura e cor da casca; cor da polpa; produtividade total e comercial; percentual de sólidos solúveis totais (SST); acidez total titulável (ATT); ratio (relação SST/ATT); umidade e rendimento de amido. O genótipo CNPH 53 apresentou a maior produtividade total estimada com 26,78 t/ha e o genótipo Brazlândia Rosada se destacou para a produtividade comercial estimada obtendo 13,75 t/ha. O genótipo CNPH 71 obteve o melhor desempenho apresentando o menor número de furos $(9,09)$ e incidência de danos $(2,44)$, tendo grau de resistência moderadamente suscetível. Também os genótipos Georgia Improved, Balão, CNPH 53, Batata Africana 1 e Batata Correntina $n^{\circ} 24$ se classificaram como moderadamente suscetíveis. O genótipo CNPH $29(158,89 \mathrm{~mm})$ apresentou melhor resultado para o comprimento das raízes. Os genótipos Brazlândia Rosada e Batata africana 1 demonstraram a maior espessura da casca com 0,11 cm. Os genótipos Georgia Improved $(1,87)$ e Santa Sofia $(1,92)$ demonstraram os melhores formatos. Dos dez genótipos estudados apenas o CNPH 71 possui cor da casca creme escuro e somente o CNPH 53 possui casca roxa, quanto ao restante $30 \%$ possui cor da casca creme e $50 \%$ cor da casca rosado. Em relação à cor da polpa $80 \%$ apresentou a polpa creme e $20 \%$ creme escuro. O genótipo CNPH $53(12,25)$ demonstrou o 
melhor resultado para o teor de SST. Com relação à acidez foram superiores: Santa Sofia (2,37 \%), CNPH 29 (2,53 \%), CNPH 53 (2,76 \%) e CNPH 71 (3,10 \%). A razão ratio desse estudo demonstrou os melhores resultados para os tratamentos CNPH $53(4,42)$, Santa Sofia $(4,25)$, CNPH 29 (4,24) e CNPH 71 (4,17), sendo os genótipos mais precoces dentre os estudados. Apenas os genótipos Princesa $(70,18)$ e CNPH $29(70,91)$ obtiveram teor de umidade próximo de 70\%. Os genótipos CNPH 53 (11,98\%), Princesa (11,38\%), CNPH 29 $(10,39 \%)$ e Georgia Improved $(9,78 \%)$ se destacaram como os mais promissores obtendo os maiores teores de amido. A produtividade comercial estimada, umidade e amido demonstraram valores de herdabilidade acima de $90 \%$ e valores superiores a 1 para a razão $\mathrm{CVg} / \mathrm{CVe}$, com indicação de pequeno efeito ambiental e seleção efetiva para estas características, mesmo utilizando métodos simples de melhoramento genético.

Palavras-chave: Ipomoea, resistência, insetos de solo, produtividade, qualidade de raiz. 


\section{PRODUCTIVITY AND RESISTANCE OF SWEET POTATO CLONES TO SOIL INSECTS}

\section{ABSTRACT}

The sweet potato is considered a rustic culture and with a high production potential, is highly resistant to pests, poor response to fertilizer application and grows in poor and degraded soils. Still, the crop is susceptible to a large number of pests and diseases. The search and characterization of pests and disease resistance sources has been the subject of much research in order to select and recommend sweet potato cultivars for different regions of the country. The objective of this study was to evaluate 10 sweet potato genotype as to productivity and to resistance to soil insects under the conditions of savannah of Federal District. The evaluated genotype were derived from the Germplasm Bank of Embrapa Vegetables (CNPH) and the experiment was conducted at Fazenda Água Limpa FAL/UnB. The experiment was conducted using the randomized complete block design with 10 treatments, 4 replicates and 10 genotype of sweet potato per plot. Were evaluated 10 genotypes: Princesa (CNPH 3), Brazlândia Rosada (CNPH 9), Santa Sofia (CNPH 17), CNPH 29, Georgia Improved (CNPH 31), Balão (CNPH 46), CNPH 53, Batata Africana 1 (CNPH 61), Batata Correntina ${ }^{\circ} 24(\mathrm{CNPH} 66)$ and $\mathrm{CNPH}$ 71. The characteristics evaluated were: number of holes; incidence of damage; grade resistance; shape and length root; thickness and color of the shell; pulp color; total and commercial productivity; percentage of total soluble solids $\left(\mathrm{SST} /{ }^{\circ}\right.$ brix $)$; titratable acidity (ATT); ratio (TSS/ATT); moisture and starch income. The genotype CNPH 53 had the highest total productivity estimated with $26,78 \mathrm{t} / \mathrm{ha}$ and the genotype Brazlândia Rosada stood out to commercial productivity estimated obtaining 13,75 t/ha. The genotype CNPH 71 performed best presenting the smallest number of holes $(9,09)$ and the incidence of damage $(2,44)$, and had degree of resistance moderately susceptible. Also the genotypes Georgia Improved, Balão, CNPH 53, Batata Africana 1 and Batata Correntina $\mathrm{n}^{\mathrm{o}} 24$ were classified as moderately susceptible. The genotype CNPH 29 (158,89 mm) showed better results for the length of the roots. The genotypes Brazlândia Rosada and Batata Africana 1 obtained the bigger thickness of the shell with $0,11 \mathrm{~cm}$. The genotype Georgia Improved $(1,87)$ and Santa Sofia $(1,92)$ showed the best formats. Of the ten genotypes only studied the CNPH 71 has shell color dark cream and only CNPH 53 has purple shell, for the rest $30 \%$ had cream color shell and 50\% color pink shell. Regarding the color of the pulp 80\% presents the cream pulp and 20\% dark cream. The CNPH $53(12,25)$ showed the best result for the brix content. Regarding the acidity the results were higher: Santa Sofia $(2,37 \%)$, 
CNPH 29 (2,53\%), CNPH 53 (2,76\%) and CNPH 71 (3,10\%). The ratio reason of this study showed the best results for the treatment CNPH $53(4,42)$, Santa Sofia $(4,25)$, CNPH 29 $(4,24)$ and CNPH $71(4,17)$, and the earliest genotype from studied. Just Princesa $(70,18)$ and CNPH 29 (70,91) obtained moisture content close to 70\%. The genotypes CNPH $53(11,98$ $\%)$, Princesa (11,38 \%), CNPH 29 (10,39\%) and Georgia Improved (9,78\%) stood out as the most promising obtaining the highest percentages starch. The commercial productivity estimated, moisture and starch showed heritability values above $90 \%$ and values greater than 1 for the reason $\mathrm{CVg} / \mathrm{CVe}$, with indication environmental low effect and effective selection for these characteristics, even using simple breeding methods.

Keywords: Ipomoea, resistance, soil insects, productivity, root quality. 


\section{INTRODUÇÃO}

Os insetos-praga são animais pertencentes ao Filo Arthropoda (Classe Insecta), caracterizam-se, de forma geral, por apresentarem o corpo segmentado dividido em três regiões (cabeça, tórax e abdome) e os seguintes apêndices: duas antenas, seis pernas e na grande maioria, duas ou quatro asas. Esses animais são de grande importância econômica pelos danos que causam as plantas (FERREIRA, 2006).

O grande papel do melhoramento genético de plantas tem sido o aumento da produtividade agrícola, em função da grande necessidade de uma fonte adequada de alimento para satisfazer o constante crescimento da população humana. Esse aumento da produtividade agrícola poderá ser conseguido tanto pelo desenvolvimento de variedades altamente produtivas, quanto pela obtenção de variedades que contribuam para estabilizar a produção, em que se destaca, entre outros fatores, a resistência a insetos-praga (FERREIRA, 2006).

O uso de variedades resistentes se constitui no método ideal de controlar os insetospraga, por diversas razões: reduz as populações de insetos a níveis que não causam danos econômicos; não interfere no ecossistema, pois não promove desequilíbrio ambiental; seu efeito é acumulativo e persistente; não é poluente; não há aumento no custo de produção, pois o seu controle se resume ao preço da própria semente e por fim não exige conhecimentos específicos por parte dos agricultores para sua utilização (FERREIRA, 2006).

Portanto, fica evidente a importância do melhoramento de plantas visando à resistência aos insetos-praga, pois o uso de variedades resistentes, além de exercer um papel estabilizador da produção, contribui para minimizar a aplicação de inseticidas, reduzindo, com isso, o custo de produção e evitando uma agressão ao meio ambiente (FERREIRA, 2006).

Dentre as principais pragas-chave presentes na cultura da batata-doce estão à brocada-raiz (Euscepes postfasciatus - Coleoptera, Curculionidae) e a broca-das-hastes (Megastes pusialis - Lepidoptera, Pyralidae) ocorrendo com maior frequência e geralmente causando danos severos se não forem tomadas medidas de controle (SILVA et al., 2008). De acordo com Silva et al. (2008), a larva-arame (Conoderus sp. - Coleoptera, Elateridae), as vaquinhas (Diabrotica speciosa, Diabrotica bivittula e Sternocolaspis quatuordecimcostata Coleoptera, Chrysomelidae), o negrito (Typophorus negritus) e o gorgulho da batata-doce (Cylas spp. - Coleoptera, Brentidae) são também muito frequentes, mas geralmente menos agressivos e, portanto, podem ocasionalmente ser considerados pragas, em condições que favoreçam a intensa reprodução do inseto. 
Outros insetos, como pulgões (Myzus sp., Aphis sp.), cigarras (Empoasca sp.), lagartarosca (Agrotis ipsilon), lagartas da folhagem (Syntomeida melanthus) e o bicho-bolo (Dyscinetus planatus) raramente causam danos de importância econômica. As formigas cortadeiras se constituem praga importante somente na fase de implantação da cultura, pois cortam brotações novas da rama, podendo provocar falhas na lavoura (SILVA et al., 2008).

Os danos são variáveis e podem ser observados em todas as partes do tecido vegetal. Os insetos podem atacar raízes, caules, ramos, folhas e frutos das plantas causando definhamento ou destruindo os tecidos, cujas lesões servem frequentemente de porta de entrada para a invasão de microrganismos, comprometendo total ou parcialmente a produção (FERREIRA, 2006).

Esse trabalho teve como objetivo avaliar 10 genótipos de batata-doce quanto à produtividade e a resistência a insetos de solo, nas condições do cerrado do Distrito Federal. 


\section{MATERIAL E MÉTODOS}

\section{1 - Obtenção do material genético}

Os genótipos utilizados foram oriundos do Banco de Germoplasma da Embrapa Hortaliças (CNPH), sendo todos mantidos cuidadosamente em campos isolados para garantir o vigor e a sanidade dos mesmos. Na tabela 1 são apresentados os 10 genótipos e suas respectivas denominações, sendo que alguns deles não são cultivares conhecidas e não possuem nome comum.

Tabela 1 - Genótipos do Banco de Germoplasma (BAG) de batata-doce da Embrapa Hortaliças. FAV/UnB, 2015.

\begin{tabular}{cc}
\hline Genótipos do BAG & Denominação Cultivares/Clones \\
\hline CNPH 3 & Princesa \\
CNPH 9 & Brazlândia Rosada \\
CNPH 17 & Santa Sofia \\
CNPH 29 & - \\
CNPH 31 & Georgia Improved \\
CNPH 46 & Balão \\
CNPH 53 & - \\
CNPH 61 & Batata Africana 1 \\
CNPH 66 & Batata Correntina ${ }^{\circ} 24$ \\
CNPH 71 & - \\
\hline
\end{tabular}

\section{2 - Localização}

O ensaio foi instalado e conduzido a campo na Fazenda Água Limpa (FAL), pertencente à Universidade de Brasília (UnB), situada no Núcleo Rural Vargem Bonita ao sul de Brasília (DF). A FAL possui uma área de 4500 ha, estando a $1.100 \mathrm{~m}$ de altitude entre $16^{\circ}$ de latitude sul e $48^{\circ}$ de longitude oeste. O clima da região é caracterizado por duas estações típicas: verão chuvoso de outubro a abril e inverno seco de maio a setembro. O ensaio foi conduzido a partir do dia 27/01/2014 a 10/07/2014, havendo uma precipitação média de $123,63 \mathrm{~mm}$, temperatura média $19,59{ }^{\circ} \mathrm{C}$ e umidade relativa do ar média de $78,21 \%$.

\section{3 - Preparo da área}

Primeiramente foi realizada a análise de solo da área de plantio para a caracterização do mesmo, constatando solo do tipo Latossolo Vermelho-Amarelo com textura média. Logo após foi executada a aplicação de calcário seguida de aração profunda $(25 \mathrm{~cm})$, visando maior revolvimento do solo para incorporação do calcário e dos restos culturais. Aproximadamente 
7 dias depois, foi realizada nova aração seguida de gradagem (figura 1). Por fim, foram feitos os camalhões de 1,0 m de largura por 4,0 m de comprimento, equidistantes em 1,0 m, nos quais foi realizado o plantio dos genótipos estudados (figura 2).

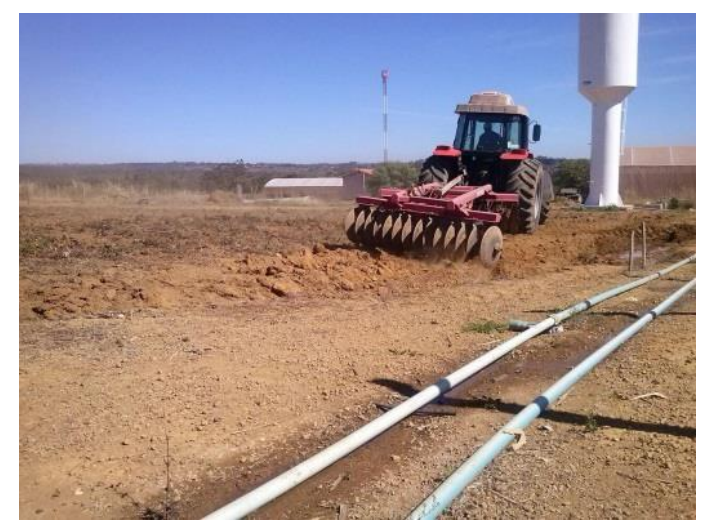

Fig.1 - Preparo da área de plantio para instalação do ensaio, localizada na Fazenda Água Limpa (FAL), pertencente à Universidade de Brasília. UnB, Brasília, 2015. Foto: Daiane S. Nóbrega.

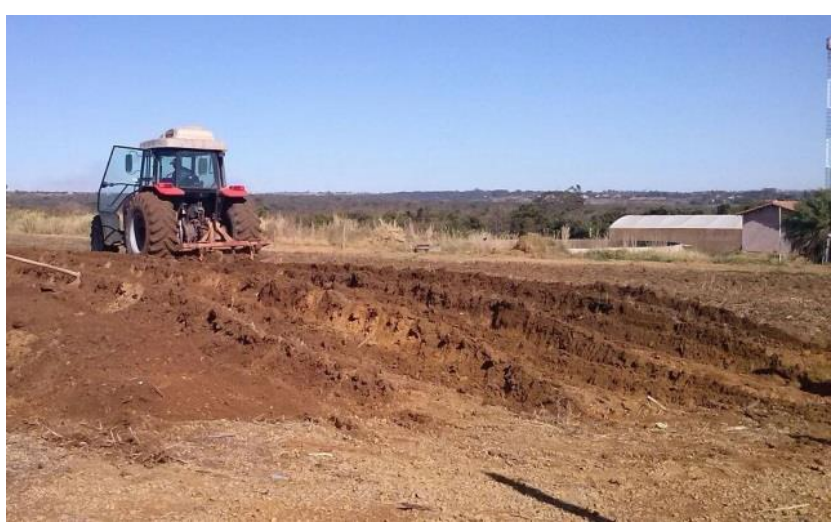

Fig. 2 - Preparo dos camalhões de plantio para instalação do ensaio na FAL, pertencente à Universidade de Brasília. UnB, Brasília, 2015. Foto: Daiane S. Nóbrega.

\section{4 - Delineamento experimental}

O ensaio foi instalado utilizando-se o delineamento experimental de blocos casualizados com 10 tratamentos. Foram utilizadas 4 repetições, com 10 plantas de batatadoce/parcela, totalizando 40 parcelas e 400 plantas.

\section{5 - Instalação do experimento}

Os genótipos foram plantados em parcelas contendo 10 estacas de batata-doce e espaçamento entre plantas de $0,40 \mathrm{~m}$ dentro do camalhão (figura 3 ). No plantio foi realizado o enterrio de estacas (ramas), previamente enraizadas em bandejas de poliestireno, com aproximadamente $20 \mathrm{~cm}$ de comprimento, contendo 3 a 4 gemas, ficando apenas 1 a 2 gemas enterradas no solo (figura 4). O plantio foi executado em janeiro de 2014 (27/01/2014), sendo feito de forma que a estaca ficasse levemente inclinada para o favorecimento da ação de hormônios de enraizamento da própria espécie. 


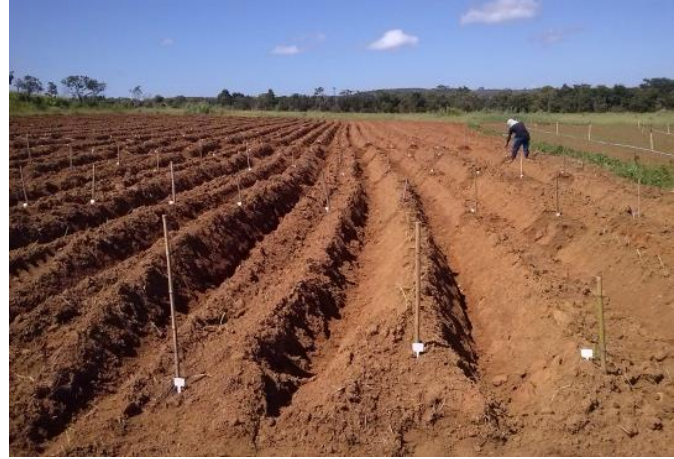

Fig. 3 - Área de plantio com divisão das parcelas para instalação do ensaio na FAL, pertencente à Universidade de Brasília. UnB, Brasília, 2015. Foto: Daiane S. Nóbrega.

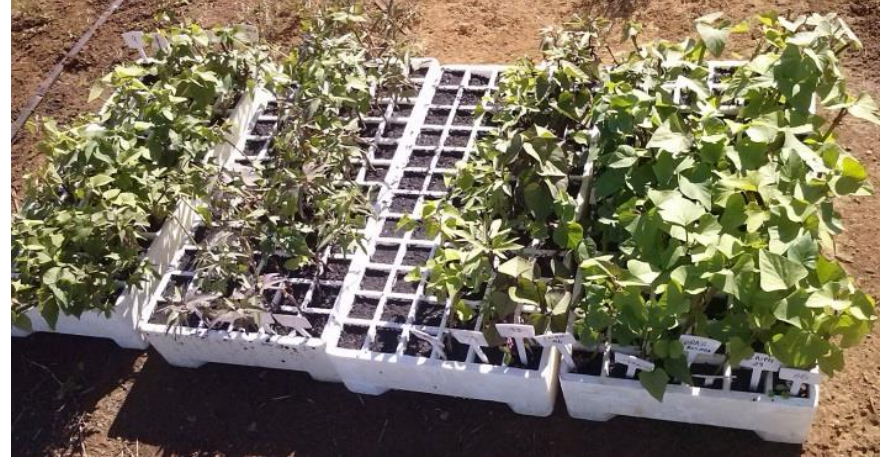

Fig. 4 - Estacas dos genótipos de batata-doce pré-enraizadas em bandejas de poliestireno, utilizadas para plantio do ensaio na FAL, pertencente à Universidade de Brasília. UnB, Brasília, 2015. Foto: Daiane S. Nóbrega.

\section{6 - Condução do experimento}

Durante o desenvolvimento da cultura foi aplicado, via artificial e natural (chuvas), aproximadamente $4,3 \mathrm{~mm}$ de água ao dia, com uso de aspersão convencional, além das precipitações que ocorreram durante a condução, totalizando $700 \mathrm{~mm}$ no ciclo de 164 dias, valor superior ao indicado por Silva et al. (2008) que citam aproximadamente $500 \mathrm{~mm}$.

Foi efetuada adubação de cobertura quinzenalmente. Inicialmente foi utilizada a dosagem de $10 \mathrm{~g} /$ planta de sulfato de amônio e $5 \mathrm{~g} /$ planta de cloreto de potássio. Quinze dias após o plantio a dosagem foi modificada para $15 \mathrm{~g} /$ planta de sulfato de amônio e 10 gramas/planta cloreto de potássio. O controle de plantas daninhas foi realizado inicialmente por meio de pulverizações com Paraquat ${ }^{\circledR}\left(300 \mathrm{ml} / 20 \mathrm{~L}\right.$ de água) e $2.4-\mathrm{D}^{\circledR}(150 \mathrm{ml} / 20 \mathrm{~L}$ de água) efetuando a proteção das mudas de batata-doce e após o desenvolvimento da cultura foi feito com capinas manuais.

\section{7 - Avaliações}

A colheita foi realizada em julho de 2014 (10/07/2014), 164 dias após o plantio, sendo as batatas colhidas manualmente (figura 5). Estas foram lavadas em água corrente e em seguida avaliadas as seguintes características: número de furos; incidência de danos; grau de resistência; formato e comprimento de raiz; espessura e cor da casca; cor da polpa; produtividade total e comercial estimadas. Também foram analisadas características químicas das raízes tais como: percentual de sólidos solúveis totais (SST), acidez total titulável (ATT), ratio (relação SST/ATT), rendimento de amido e umidade. 


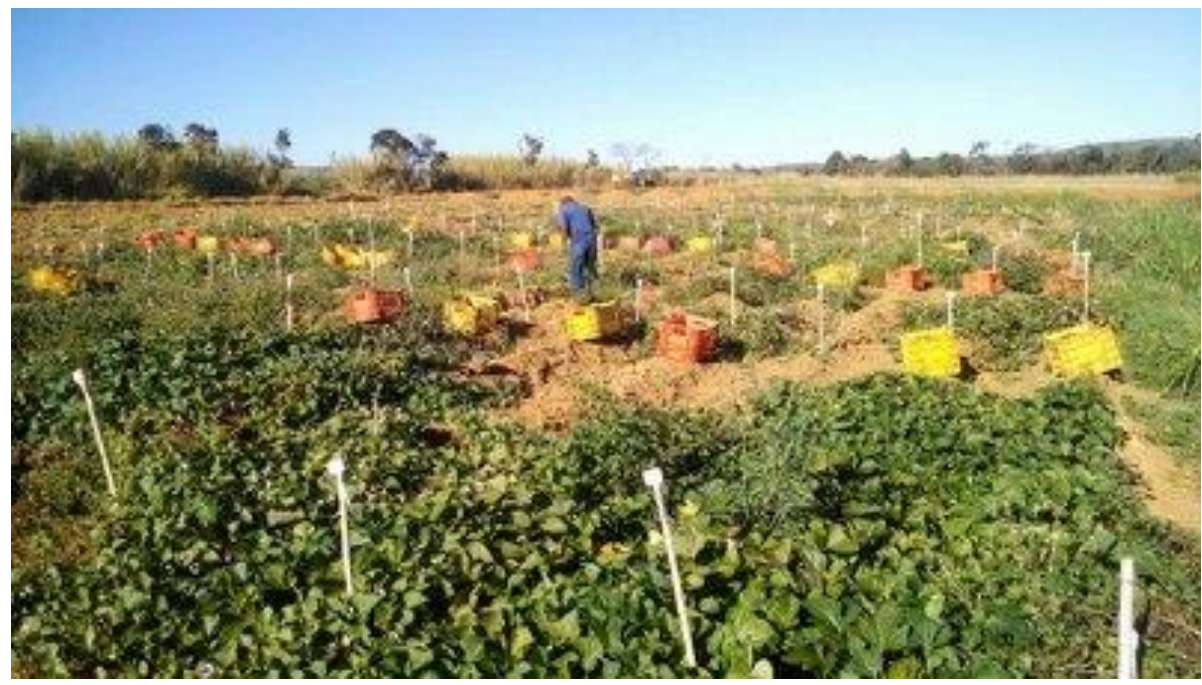

Fig. 5 - Cultura da batata-doce desenvolvida aos 164 dias após o plantio e início da execução da colheita do ensaio, localizado na FAL, pertencente à Universidade de Brasília. UnB, Brasília, 2015. Foto: Daiane S. Nóbrega.

\section{1 - Número de furos por raiz, incidência de danos e grau de resistência}

Foram escolhidas ao acaso sete batatas por parcela e efetuada a contagem do número de furos efetuados por insetos e a classificação da incidência de danos, baseada no número de furos e na escala de notas estabelecida por França et al. (1983).

A escala proposta por França et al. (1983) varia de 1 a 5 como demonstrado abaixo:

1 - Corresponde às raízes livres de danos causados por insetos, apresentando um aspecto comercial desejável;

2 - Representa raízes com poucos danos, mas que perde um pouco o aspecto comercial, pois os danos neste caso podem ser observados, apesar de pequenos;

3 - Os danos já são verificados sem muito esforço visual, o que prejudica o aspecto comercial das raízes;

4 - Aquelas raízes que apresentam danos muito claros, tornando a batata praticamente imprestável para comercialização;

5 - Batatas fora dos padrões comerciais e muitas vezes não utilizadas nem mesmo para fins de consumo animal.

Baseado na escala de notas de incidência de danos, proposta por França et al. (1983), e a partir das médias obtidas em cada parcela do ensaio, os genótipos foram classificados segundo o grau de resistência aos insetos de solo, como apresenta a tabela 2 abaixo: 
Tabela 2 - Classificação da resistência com base na incidência de danos média de cada parcela. FAV/UnB, 2015.

\begin{tabular}{cc}
\hline Nota & Grau de resistência \\
\hline$\leq \mathbf{1}$ & Resistente (R) \\
$\leq \mathbf{2}$ & Moderadamente Resistente (MR) \\
$\leq \mathbf{3}$ & Moderadamente Suscetível (MS) \\
$\mathbf{4}$ & Suscetível (S) \\
$\mathbf{5 5}$ & Altamente Suscetível (AS) \\
\hline
\end{tabular}

Grau de resistência segundo França et al. (1983).

\section{2 - Formato da raiz}

O formato da raiz foi avaliado por meio da atribuição de notas, segundo a escala proposta por Massaroto (2008), escolhendo-se ao acaso sete raízes por parcela.

A escala estabelecida por Massaroto (2008) varia de 1 a 5, como demonstrado abaixo:

1 - Corresponde a um formato praticamente ideal para batata-doce, sendo um formato fusiforme regular e sem veias ou qualquer tipo de rachadura, por isso considerado um excelente formato.

2 - Formato considerado bom, mas que apresenta algumas características indesejáveis como a presença de veias ou o formato mais desuniforme.

3 - Raízes desuniformes com veias e com rachaduras, que se apresentam bastante irregulares e grandes.

4 - Raízes indesejáveis do ponto de vista comercial: muito grandes, com rachaduras e com presença de veias.

5 - Corresponde às raízes totalmente fora dos padrões comercialmente desejados, apresentando veias, rachaduras e muito irregulares.

\section{3 - Comprimento da raiz}

O comprimento médio da raiz foi obtido mensurando-se 7 raízes por parcela escolhidas ao acaso. Para tanto foi efetuada a medição do eixo longitudinal da raiz com o uso de uma régua. A leitura foi expressa em milímetros ( $\mathrm{mm})$.

\section{4 - Espessura da casca}

A espessura média da casca da raiz foi obtida pela mensuração de 7 raízes por parcela escolhidas ao acaso, na porção mediana das raízes após ser efetuado um corte transversal, com o auxílio de um paquímetro digital. A leitura foi expressa em milímetros (mm). 


\section{5 - Cor da casca e da polpa}

A coloração da casca e da polpa das raízes de batata-doce foi avaliada visualmente variando de 1 a 10 e de 1 a 9 (figura 6 e 7), respectivamente, adotando-se uma escala de notas proposta por Kalkmann (2011). Foram atribuídas notas a 7 raízes por parcela, escolhidas ao acaso.

\begin{tabular}{|cccccccccc|}
\hline 1 & 2 & $\mathbf{3}$ & $\mathbf{4}$ & $\mathbf{5}$ & $\mathbf{6}$ & 7 & $\mathbf{8}$ & $\mathbf{9}$ & 10 \\
BRANCO & CREME & $\begin{array}{c}\text { CREME } \\
\text { ESCURO }\end{array}$ & $\begin{array}{c}\text { AMARELO } \\
\text { PÁLIDO }\end{array}$ & ROSADO & $\begin{array}{c}\text { MARROM } \\
\text { ALARANJADO }\end{array}$ & ROXO & $\begin{array}{c}\text { ROXO } \\
\text { ESCURO }\end{array}$ & $\begin{array}{c}\text { ROXO } \\
\text { AVERME- } \\
\text { LHADO }\end{array}$ & VINHO \\
\hline
\end{tabular}

Fig. 6 - Escala de notas utilizada para a classificação da cor da casca (Kalkmann, 2011).

\begin{tabular}{|ccccccccc|}
\hline 1 & 2 & 3 & 4 & 5 & 6 & 7 & 8 & 9 \\
BRANCO & CREME & $\begin{array}{c}\text { CREME } \\
\text { ESCURO }\end{array}$ & $\begin{array}{c}\text { AMARELO } \\
\text { CLARO }\end{array}$ & AMARELO & $\begin{array}{c}\text { AMARELO } \\
\text { ESCURO }\end{array}$ & $\begin{array}{c}\text { ALARANJAdo } \\
\text { PÁldDO }\end{array}$ & ARROXEAda & $\begin{array}{c}\text { PIGMIEN- } \\
\text { TADA ROXa }\end{array}$ \\
\hline
\end{tabular}

Fig. 7 - Escala de notas utilizada para a classificação da cor da polpa (Kalkmann, 2011).

\section{6 - Produtividade total e comercial estimada}

A produtividade total estimada foi obtida por meio da pesagem de todas as raízes pertencentes à mesma parcela com auxílio de uma balança, com aproximação em centigramas, e o valor resultante foi extrapolado para toneladas/ha.

A produtividade comercial estimada foi obtida pela seleção e classificação das raízes de cada parcela de acordo com os padrões comerciais (descartadas raízes muito grandes, muito pequenas, com deformações excessivas, consideradas impróprias para a comercialização) e foi efetuada uma nova pesagem somente das raízes selecionadas de cada parcela. O valor obtido foi extrapolado para toneladas/ha.

\section{Características químicas da raiz}

Após as avaliações realizadas em campo foram selecionadas aproximadamente 3 raízes de cada parcela e executadas análises laboratoriais. As raízes foram trituradas com auxílio de um processador de alimentos e resfriadas a $5^{\circ} \mathrm{C}$ para conservação de suas características originais.

\section{7 - Percentual de sólidos solúveis totais (SST)}

O teor de sólidos solúveis totais foi determinado por refratometria, utilizando-se refratômetro digital portátil, com leitura na faixa de $0^{\circ}$ a $32^{\circ}$ brix. Para aferir o teor de SST foi 
realizada a extração de uma alíquota de polpa da batata-doce em cada parcela, utilizando algodão para efetuar a filtração.

\section{8 - Acidez total titulável (ATT)}

A acidez total titulável foi determinada de acordo com a metodologia recomendada pelo Instituo Adolfo Lutz (2005) que consiste em titular com solução alcalina padrão a acidez da polpa de batata-doce. Primeiramente foi preparada a solução padrão de $\mathrm{NaOH} 0,1 \mathrm{M}$ e calculado o fator de correção da solução por meio da seguinte equação:

$$
f=\frac{V \text { teórico }}{V \text { gasto }}
$$

Onde:

$\mathrm{V}$ teórico = volume de solução que se espera gastar na titulação $(\mathrm{ml})$

$\mathrm{V}$ gasto $=$ volume de solução gasto na titulação $(\mathrm{ml})$.

O fator de correção encontrado para a solução de $\mathrm{NaOH} \mathrm{0,1} \mathrm{M} \mathrm{foi} \mathrm{de} \mathrm{0,9996.}$

Em seguida foram preparadas amostras de cada parcela contendo $10 \mathrm{~g}$ de polpa diluída em $50 \mathrm{ml}$ de água destilada. A titulação foi feita em bureta de $25 \mathrm{ml}$, sob agitação, utilizado 3 gotas de fenolftaleína como indicador.

Os resultados foram expressos em \% de acidez, após a utilização da seguinte fórmula:

$$
\% \text { Acidez }=\frac{\operatorname{Vg} \times \mathbf{f} \times 100}{\text { P x c }}
$$

Onde:

$\mathrm{Vg}$ = volume da solução de $\mathrm{NaOH}$ 0,1 M gasto na titulação (ml)

$\mathrm{f}=$ fator de correção da solução de $\mathrm{NaOH} 0,1 \mathrm{M}$

$\mathrm{P}=$ peso da amostra usado na titulação $(\mathrm{g})$

$\mathrm{c}=$ correção para solução de $\mathrm{NaOH} 1 \mathrm{M}: 10$ para solução $\mathrm{NaOH}$ 0,1 M.

\section{9 - Relação SST/ATT (ratio)}

O valor da relação SST/ATT foi obtido por meio da razão do teor de sólidos solúveis totais e da acidez total titulável, observados em cada parcela. Essa relação é também chamada 
ratio e constitui a melhor forma de avaliação da qualidade de um produto. Esta relação também é utilizada como uma indicação do grau de maturação da matéria prima.

\subsection{0 - Rendimento de amido}

A extração e quantificação de amido foi feita de acordo com o protocolo proposto por Zavarese et al. (2009). Foram pesados $50 \mathrm{~g}$ de polpa em balança analítica e esta foi triturada em liquidificador contendo $100 \mathrm{ml}$ de água destilada, por aproximadamente 50 segundos. Logo após a mistura foi filtrada com auxílio de um coador de café e a solução foi coletada. A solução contendo o amido em suspensão foi seca em estufa com circulação de ar a $40^{\circ} \mathrm{C}$, por 24 horas. $\mathrm{O}$ amido seco foi então pesado e expresso em gramas de amido/50 g de polpa ou \% de amido.

$$
\% \text { Rendimento de amido }=\frac{\text { g amido }}{50 \text { g de polpa }} \times 100
$$

Onde:

gramas de amido: peso do amido obtido na extração

50 g de polpa: peso da amostra utilizada para a extração de amido.

\subsection{1 - Umidade}

O cálculo da umidade ou perda por dessecação foi feito de acordo com o método proposto pelo Instituto Adolfo Lutz (2005). Pesou-se em balança analítica 1,0 g de polpa, sendo esta levada à estufa com circulação de ar a $105^{\circ} \mathrm{C}$ por 24 horas. Os resultados foram expressos em percentual de perda por dessecação ou percentual de umidade e o cálculo foi efetuado utilizando-se a seguinte fórmula:

$$
\% \text { perda por dessecação }=\frac{100 \times \mathrm{N}}{\mathrm{P}}
$$

Onde:

$\mathrm{N}=\mathrm{n}^{\circ}$ de gramas de umidade (perda de massa em $\mathrm{g}$ );

$\mathrm{P}=\mathrm{n}^{\circ}$ de gramas da amostra. 


\section{8 - Análise estatística}

Os dados foram submetidos à análise de variância, utilizando-se o teste de $\mathrm{F}$ ao nível de 5\% de probabilidade, com o auxílio do software SISVAR (FERREIRA, 2000) e para a estimativa de parâmetros genéticos foi utilizado o software GENES (CRUZ, 1997).

Somente os dados de produtividade total estimada e número de furos foram transformados para raiz quadrada de X para atender à pressuposição de normalidade de distribuição e então submetidos à análise de variância, utilizando para o teste de $\mathrm{F}$ o nível de $5 \%$ de probabilidade. As médias foram agrupadas pelo teste de Scott-Knott com o auxílio do software SISVAR (FERREIRA, 2000).

As demais variáveis (produtividade comercial estimada; incidência de danos; comprimento e formato de raízes; espessura de casca; umidade; amido; acidez total titulável; sólidos solúveis totais e ratio) não houve transformação, sendo analisadas quanto à variância de seus dados pelo teste de $\mathrm{F}$ a $5 \%$ de probabilidade e as médias dos tratamentos foram comparadas pelo teste Scott-Knott com o auxílio do software SISVAR (FERREIRA, 2000).

Foi estimada a herdabilidade no sentido amplo $\left(\mathrm{h}_{\mathrm{a}}{ }^{2}\right)$, o coeficiente de variação genético $\left(\mathrm{CV}_{\mathrm{g}}\right)$ e a relação entre o coeficiente de variação genético e ambiental $\left(\mathrm{CV}_{\mathrm{g}} / \mathrm{CV}_{\mathrm{e}}\right)$, utilizando-se o aplicativo GENES (CRUZ, 1997).

Foram obtidas as estimativas de variâncias genotípica $\left(\widehat{\boldsymbol{\sigma}}_{\mathbf{g}}^{\mathbf{2}}\right)$, variância ambiental média $\left(\widehat{\boldsymbol{\sigma}}_{\mathbf{e}}^{\mathbf{2}}\right)$, herdabilidade no sentido amplo $\left(\mathrm{h}_{\mathrm{a}}{ }^{2}\right)$, coeficientes de variação experimental (CVe) e genético $(\mathrm{CVg})$ e relação entre o coeficiente de variação genético e ambiental $\left(\mathrm{CV}_{\mathrm{g}} / \mathrm{CV}_{\mathrm{e}}\right)$, para todas as características de campo, utilizando-se o programa Genes (Cruz,1997), em que:

Variância fenotípica entre as médias dos tratamentos: $\hat{\sigma}_{f}^{2}=\frac{Q M g}{r}$

Variância ambiental: $\hat{\sigma}_{e}^{2}=\frac{Q M e}{r}$

Variância genotípica: $\hat{\sigma}_{g}^{2}=\frac{Q M g-Q M e}{r}$

Herdabilidade ao nível de média: $h_{a}^{2}(\%)=\frac{\widehat{\sigma}_{g}^{2}}{\frac{Q M g}{r}} 100$

Coeficiente de variação experimental: $\operatorname{CVe}(\%)=\frac{\sqrt{Q M e}}{\bar{x}} 100$, 
onde $\mathrm{x}=$ média do carácter considerado.

Coeficiente de variação genético: $\operatorname{CVg}(\%)=\frac{\sqrt{\widehat{\sigma}_{g}^{2}}}{\bar{x}} 100$ 


\section{RESULTADOS E DISCUSSÃO}

Foram observadas diferenças significativas entre os tratamentos para todas as características analisadas, com exceção da produtividade total estimada (t/ha), comprimento $(\mathrm{mm})$ e a espessura da casca $(\mathrm{mm})$ baseado na análise de variância a $5 \%$ de probabilidade (tabelas 3 e 5). As características número de furos, produtividade comercial estimada (t/ha), formato, umidade (\%) e amido (\%) foram significativas a $1 \%$, enquanto a incidência de danos, ATT (\%), SST ( ${ }^{\circ}$ brix) e ratio demonstraram significância a 5\% de probabilidade na análise de variância (tabelas $3,4,5$ e 7).

A produtividade total, comprimento e SST não apresentaram diferença estatística significativa entre as médias dos tratamentos, pelo teste de Scott-Knott.

Tabela 3 - Médias da produtividade total e comercial estimadas dos genótipos avaliados. FAV/UnB, 2015.

\begin{tabular}{ccc}
\hline $\begin{array}{c}\text { Genótipos do } \\
\text { BAG }\end{array}$ & $\begin{array}{c}\text { Produtividade } \\
\text { total (t/ha) }\end{array}$ & $\begin{array}{c}\text { PS } \\
\text { Pomercial (t/ha)** }\end{array}$ \\
\hline Princesa & $6,09 \mathrm{a}$ & $3,29 \mathrm{c}$ \\
Brazlândia Rosada & $17,54 \mathrm{a}$ & $13,75 \mathrm{a}$ \\
Santa Sofia & $11,77 \mathrm{a}$ & $11,25 \mathrm{a}$ \\
CNPH 29 & $11,39 \mathrm{a}$ & $3,16 \mathrm{c}$ \\
Georgia Improved & $4,67 \mathrm{a}$ & $4,17 \mathrm{c}$ \\
Balão & $8,75 \mathrm{a}$ & $2,42 \mathrm{c}$ \\
CNPH 53 & $26,78 \mathrm{a}$ & $5,16 \mathrm{c}$ \\
Batata Africana 1 & $8,80 \mathrm{a}$ & $2,92 \mathrm{c}$ \\
Batata Correntina n ${ }^{\circ} 24$ & $6,41 \mathrm{a}$ & $3,75 \mathrm{c}$ \\
CNPH 71 & $5,18 \mathrm{a}$ & $8,33 \mathrm{~b}$ \\
\hline Média & 99,71 & 5819,27 \\
\hline CV (\%) & 71,11 & 38,61 \\
\hline ** Significativo a $1 \%$ pelo teste F. ${ }^{\text {Ns }}$ Não-significativo a 5\% pelo teste F. Médias seguidas pela mesma letra minúscula nas colunas não
\end{tabular}

Houve ampla variação no desempenho agronômico entre genótipos, em termos de produtividade total ( $\mathrm{t} / \mathrm{ha}$ ), no entanto, as mesmas não diferiram significativamente entre si (tabela 3). Os genótipos que apresentaram o melhor desempenho foram CNPH 53 (26,78 t/ha), Brazlândia rosada (17,54 t/ha), Santa Sofia (11,77 t/ha) e CNPH 29 (11,39 t/ha). O genótipo menos produtivo foi Georgia Improved com 4,67 t/ha.

As médias de produtividade comercial dos genótipos diferiram entre si e as cultivares Brazlândia Rosada e Santa Sofia demonstraram-se superiores aos demais tratamentos, com $13,75 \mathrm{t} / \mathrm{ha}$ e $11,25 \mathrm{t} / \mathrm{ha}$ respectivamente. Os valores de produtividade comercial e total do 
genótipo Brazlândia Rosada foram inferiores aos observados por Carmona et al. (2015) que obtiveram produtividades correspondentes a $27,28 \mathrm{t} / \mathrm{ha}$ e $28,57 \mathrm{t} / \mathrm{ha}$ respectivamente.

O presente estudo apresentou valores superiores de produtividade comercial e total na cultivar Brazlândia Rosada quando comparados aos observados por Azevedo et al. (2015) em Diamantina-MG, que encontraram 10,20 t/ha e 13,00 t/ha respectivamente.

O genótipo CNPH 71 demonstrou produtividade comercial de 8,33 t/ha, diferenciando-se estatisticamente das cultivares Brazlândia Rosada e Santa Sofia. Ainda com relação ao estudo de Carmona et al. (2015), os valores de produtividade comercial e total da CNPH 71 foram 2,81 t/ha e 4,44 t/ha, enquanto no presente trabalho alcançou médias superiores, correspondentes a 8,33 t/ha e 5,18 t/ha, respectivamente.

Os demais tratamentos apresentaram produtividades comerciais inferiores variando entre 2,42 t/ha a 5,16 t/ha não diferenciando estatisticamente entre si (tabela 3). Azevedo et al. (2015), avaliando 65 genótipos de batata-doce em Diamantina-MG obtiveram baixas produtividades comerciais em 46 genótipos, variando de 2,23 t/ha a 7,70 t/ha, sendo esse intervalo de dados próximo ao observado no presente estudo.

A produtividade total dos genótipos CNPH 53 (26,78t/ha) e Brazlândia Rosada (17,54t/ha), e a produtividade comercial do genótipo Brazlândia Rosada (13,75t/ha) apresentaram-se superiores à média nacional de 12,4 t/ha, segundo a safra de 2011 (IBGE, 2012). Os demais genótipos demonstraram baixa produtividade total e comercial, podendo estar relacionadas à sanidade do material genético, pois o processo de multiplicação vegetativa, através de ramas e raízes, favorece a disseminação de doenças, principalmente viroses. Provavelmente, está ligado também a outros fatores como as condições edafoclimáticas locais, variedades pouco produtivas e o baixo nível tecnológico empregado (KALKMANN, 2011). Além disso, a época em que foi realizada as avaliações do presente estudo foi tardia (5,5 meses) desfavorecendo a produtividade comercial dos clones de ciclo médio e mais precoces. 
Tabela 4 - Médias das variáveis número de furos e incidência de danos causados por insetos de solo e respectivo grau de resistência dos tratamentos avaliados. FAV/UnB, 2015.

\begin{tabular}{cccc}
\hline $\begin{array}{c}\text { Genótipos do } \\
\text { BAG }\end{array}$ & Número de furos** & $\begin{array}{c}\text { Incidência de } \\
\text { danos* } \\
\text { (nota de 1 a 5) }\end{array}$ & $\begin{array}{c}\text { Grau de } \\
\text { resistência } \\
\text { (nota de 1 a 5) }\end{array}$ \\
\hline Princesa & $55,91 \mathrm{c}$ & $3,37 \mathrm{~b}$ & $\mathrm{~S}$ \\
Brazlândia Rosada & $62,49 \mathrm{c}$ & $3,69 \mathrm{~b}$ & $\mathrm{~S}$ \\
Santa Sofia & $27,43 \mathrm{~b}$ & $3,13 \mathrm{~b}$ & $\mathrm{~S}$ \\
CNPH 29 & $68,43 \mathrm{c}$ & $3,41 \mathrm{~b}$ & $\mathrm{~S}$ \\
Georgia Improved & $62,06 \mathrm{c}$ & $2,61 \mathrm{a}$ & $\mathrm{MS}$ \\
Balão & $63,27 \mathrm{c}$ & $2,89 \mathrm{a}$ & $\mathrm{MS}$ \\
CNPH 53 & $35,40 \mathrm{~b}$ & $2,48 \mathrm{a}$ & $\mathrm{MS}$ \\
Batata Africana 1 & $37,58 \mathrm{~b}$ & $2,65 \mathrm{a}$ & $\mathrm{MS}$ \\
Batata Correntina $\mathrm{n}^{\circ} 24$ & $53,64 \mathrm{c}$ & $2,87 \mathrm{a}$ & $\mathrm{MS}$ \\
CNPH 71 & $9,09 \mathrm{a}$ & $2,44 \mathrm{a}$ & $\mathrm{MS}$ \\
\hline Média & 6,71 & 2,95 & - \\
\hline CV $(\%)$ & 22,19 & 19,26 & - \\
\hline
\end{tabular}

* Significativo a $5 \%$ pelo teste F. ** Significativo a $1 \%$ pelo teste F. Médias seguidas pela mesma letra minúscula nas colunas não diferem entre si pelo teste "Scott-Knott", em nível de $1 \%$ ou $5 \%$ de probabilidade.

A característica número de furos foi significativa a $1 \%$ de probabilidade enquanto a incidência de danos demonstrou-se significativa a $5 \%$ de probabilidade no teste Scott-knott. Houve grande amplitude nos resultados observados para o número de furos variando de 9,09 a 68,43 furos. Dentre os genótipos apenas o CNPH 71 apresentou menos de 10 furos (tabela 4). As notas médias para a incidência de danos variaram de 2,44 a 3,69.

Podemos destacar o genótipo CNPH 71 que demonstrou o melhor resultado com menor número de furos $(9,09)$, apresentando uma baixa incidência de danos $(2,44)$ e grau de resistência moderadamente suscetível (tabela 4).

Carmona et al. (2015), em experimento conduzido na Fazenda Água Limpa da Universidade de Brasília, localizada no Núcleo Rural Vargem Bonita ao Sul de Brasília (DF), em condições similares a deste trabalho, encontrou um valor superior de furos no genótipo CNPH $71(19,10)$, porém um valor próximo na incidência de danos $(2,14)$ e o mesmo grau de resistência, sendo esse resultado condizente com o observado no presente estudo.

Os genótipos Santa Sofia, Batata Africana 1 e CNPH 53 demonstraram valores superiores em termos de número de furos e índice de danos quando comparados ao genótipo CNPH 71, mas inferiores aos demais tratamentos. Os três tratamentos são estatisticamente semelhantes quanto ao número de furos, porém a cultivar Santa Sofia diferenciou-se estatisticamente quanto aos danos. As cultivares Santa Sofia e Batata Africana 1 foram moderadamente suscetíveis, enquanto que a cultivar Santa Sofia foi suscetível (tabela 4). 
As cultivares Batata Correntina $n^{\circ}$ 24, Georgia Improved e Balão demonstraram valores altos do número de furos apresentando 53,64; 62,06 e 63,27 furos, respectivamente (tabela 4), porém baixa incidência de danos comparados aos demais tratamentos, sendo moderadamente suscetíveis. Isso pode ocorrer porque a nota de incidência de danos não está relacionada apenas ao número de furos e sim ao aspecto comercial da raiz após a ocorrência do dano.

Os genótipos Princesa, Brazlândia Rosada, Santa Sofia e CNPH 29 não apresentaram diferença estatística entre si. Esses genótipos demonstraram nota de incidência de danos superior a 3 e suscetibilidade aos insetos de solo (tabela 4).

Peixoto et al. (1999), obtiveram incidência de danos com nota 3,00 na cultivar Brazlândia Rosada, assim como observado nesse estudo.

Azevedo et al. (2015) conduziram um experimento utilizando uma escala de notas similar a deste trabalho, porém em condições distintas, no Setor de Olericultura do Campus JK da Universidade Federal dos Vales do Jequitinhonha e Mucuri (UFVJM), município de Diamantina-MG. Observaram que a característica resistência a insetos, não teve efeito significativo para as cultivares Brazlândia Rosada e Princesa, obtendo notas médias para os danos de 1,61 e 1,85 respectivamente.

O aumento na ocorrência de danos pode estar relacionado com as diferentes condições a campo e ao maior tempo de permanência das raízes no solo, pois quanto mais tardia for à colheita maior será o tempo no qual as raízes ficam sujeitas a ação dos insetos.

Segundo Carmona et al. (2015), a redução das notas de incidência de danos está relacionada à baixa ocorrência de insetos de solo durante a condução do experimento, estando correlacionada com a frequência da irrigação. Adicionalmente, fatores ambientais e constituintes genéticos, como a quantidade de compostos fenólicos produzida nos tecidos, podem promover a resistência a insetos de solo.

Quanto ao grau de resistência foi constatado que $60 \%$ dos genótipos foram moderadamente suscetíveis e $40 \%$ dos genótipos suscetíveis (tabela 4).

Carmona (2015), em seu experimento conduzido no Núcleo Rural Vargem Bonita ao Sul de Brasília (DF), em condições similares a deste trabalho, encontrou grau de resistência diverso ao observado no presente estudo avaliando os genótipos Princesa (MR), Brazlândia Rosada (MR), CNPH 29 (MR), Balão/CNPH 46 (MR) e Batata Africana 1/ CNPH61 (MR), exceto para o CNPH 71 (MS). 
Kalkmann (2011), avaliando 25 genótipos de batata-doce, diversos dos estudados no presente trabalho, quanto à resistência a insetos de solo obteve 11 genótipos moderadamente resistentes e 14 genótipos moderadamente suscetíveis.

Estudando 21 genótipos de batata-doce quanto à resistência a insetos de solo em Brasília (DF), Schrammel (2011), observou que 17 genótipos foram moderadamente resistentes, 3 suscetíveis e apenas 1 resistente.

Não houve diferença estatística significativa no comprimento entre os genótipos de acordo com o teste Scott-Knott (tabela 5). O comprimento médio das raízes variou de 124,04 mm a 163,75 mm correspondente as cultivares Batata Africana 1 e Balão, respectivamente. Oitenta por cento dos genótipos mantiveram-se dentro da faixa de comprimento ideal, segundo Silva et al. (2008), com variação entre $120 \mathrm{~mm}$ a $160 \mathrm{~mm}$, exceto as cultivares Princesa e Balão.

Tabela 5 - Médias de comprimento, espessura da casca e formato das raízes dos tratamentos avaliados. FAV/UnB, 2015.

\begin{tabular}{|c|c|c|c|}
\hline $\begin{array}{c}\text { Genótipos do } \\
\text { BAG } \\
\end{array}$ & Comprimento $(\mathrm{mm})^{\mathrm{NS}}$ & 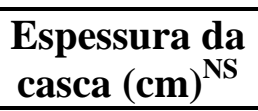 & $\begin{array}{c}\text { Formato }^{* *} \\
(\text { nota de } 1 \text { a } 5)\end{array}$ \\
\hline Princesa & $161,07 \mathrm{a}$ & $0,10 \mathrm{~b}$ & $2,25 \mathrm{a}$ \\
\hline Brazlândia Rosada & $148,93 \mathrm{a}$ & $0,11 \mathrm{~b}$ & $2,74 \mathrm{a}$ \\
\hline Santa Sofia & $152,42 \mathrm{a}$ & $0,08 \mathrm{a}$ & $1,92 \mathrm{a}$ \\
\hline CNPH 29 & $158,89 \mathrm{a}$ & $0,09 \mathrm{a}$ & $3,95 \mathrm{~b}$ \\
\hline Georgia Improved & $137,46 \mathrm{a}$ & $0,09 \mathrm{a}$ & $1,87 \mathrm{a}$ \\
\hline Balão & $163,75 \mathrm{a}$ & $0,08 \mathrm{a}$ & $2,82 \mathrm{a}$ \\
\hline CNPH 53 & $124,79 \mathrm{a}$ & $0,08 \mathrm{a}$ & $2,31 \mathrm{a}$ \\
\hline Batata Africana 1 & $124,04 \mathrm{a}$ & $0,11 b$ & $2,95 \mathrm{a}$ \\
\hline $\begin{array}{c}\text { Batata Correntina } \\
n^{\circ} 24\end{array}$ & $142,86 \mathrm{a}$ & $0,08 \mathrm{a}$ & $2,58 \mathrm{a}$ \\
\hline CNPH 71 & $127,03 \mathrm{a}$ & $0,10 \mathrm{~b}$ & $2,25 \mathrm{a}$ \\
\hline Média & 144,12 & 0,09 & 2,56 \\
\hline $\mathrm{CV} \%$ & 20,90 & 20,70 & 26,07 \\
\hline
\end{tabular}

** Significativo a $1 \%$ pelo teste $\mathrm{F}$. ${ }^{\text {NS }}$ Não-significativo a $5 \%$ pelo teste $\mathrm{F}$. Médias seguidas pela mesma letra minúscula nas colunas não diferem entre si pelo teste "Scott-Knott", em nível de $1 \%$ ou $5 \%$ de probabilidade.

A espessura da casca não demonstrou significância no teste de $\mathrm{F}$ a $5 \%$ de probabilidade, mas suas médias diferiram entre si. O genótipo CNPH $53(0,08 \mathrm{~cm})$ apresentou a menor espessura e o genótipo Brazlândia Rosada $(0,11 \mathrm{~cm})$ a maior espessura (tabela 5).

Kalkmann (2011), estudando a resistência de 25 genótipos de batata-doce em Brasília (DF) observou que o comprimento de raízes apresentou diferença significativa entre os genótipos e o tamanho médio das raízes variou entre 147,19 mm e 207,68 mm, sendo que alguns desses apresentaram tamanhos acima da faixa de comprimento ideal. A espessura da 
casca das raízes também foi avaliada demonstrando diferença significativa, com variação entre $2,05 \mathrm{~mm}$ e $3,77 \mathrm{~mm}$.

Segundo Cavalcante et al. (2009), durante a comercialização não se leva em consideração o comprimento da raiz. A classificação da batata-doce no mercado atacadista é caracterizada pela cor de sua casca, polpa, massa e qualidade. É uma raiz muito consumida pela população de baixa renda e o preço é o ponto principal na escolha do produto.

Noventa por cento dos genótipos mantiveram formatos ideais e relativamente próximos ao fusiforme (nota entre 1 e 3), o que corresponde a raízes de formato excelente e bom, enquadrando-se nos padrões comerciais para consumo. A cultivar Georgia Improved $(1,87)$ e Santa Sofia $(1,92)$ demonstraram os melhores resultados para formato. Apenas o CNPH $29(3,95)$ obteve nota acima de 3, o pior formato observado, sendo considerada de formato irregular, apresentando veias, rachaduras e grande para comercialização. Os demais tratamentos tiveram valores intermediários, diferenciando-se estatisticamente do CNPH 29 (tabela 5).

Azevedo et al. (2015), conduziram um experimento na Universidade Federal dos Vales do Jequitinhonha e Mucuri em Minas Gerais, no qual estudaram dois dos genótipos observados no presente estudo. A cultivar Brazlândia Rosada teve uma nota média para o formato de 3,23; apresentou raízes desuniformes com veias e rachaduras; danos bastante perceptíveis, irregulares, grandes e aspecto comercial prejudicado. A cultivar Princesa demonstrou nota 2,63 e enquadrou-se num formato bom para os padrões comerciais. Peixoto et al. (1999), também relataram que a cultivar Brazlândia Rosada apresentou nota 3,10 para a característica formato.

No presente trabalho as cultivares Brazlândia Rosada e Princesa obtiveram uma nota média para o formato de 2,74 e 2,25 respectivamente, classificando-se em formato bom para comercialização (tabela 5). Pode-se observar que as notas de formato encontradas para essas cultivares no presente estudo foram inferiores e apresentaram melhor formato, principalmente com relação a cultivar Brazlândia Rosada.

O experimento de Carmona et al. (2015) demonstrou resultados similares a deste estudo para a característica formato, apresentando notas semelhantes para os tratamentos Brazlândia Rosada $(2,38)$ e CNPH $71(2,00)$ e mesma classificação de formato, sendo considerados bons para consumo. As cultivares Balão/CNPH $46(3,83)$ e Batata africana 1/CNPH $61(3,17)$ alcançaram resultados inferiores à deste estudo obtendo notas maiores e 
pior classificação de formato, enquadrando-se em raízes de formato desuniformes, irregulares, grandes e aspecto comercial prejudicado.

Dentre os dez tratamentos estudados $30 \%$ demonstraram cor da casca creme e $50 \%$ cor da casca rosada. O genótipo CNPH 71 apresentou cor da casca creme escuro e o genótipo CNPH 53 casca roxa. Oitenta por cento dos genótipos apresentaram cor da polpa creme e $20 \%$ polpa creme escuro (tabela 6 ).

Tabela 6 - Coloração de casca e polpa das raízes dos genótipos de batata-doce avaliados. FAV/UnB, 2015.

\begin{tabular}{ccc}
\hline Genótipos do BAG & Cor da casca & Cor da polpa \\
\hline Princesa & creme & creme \\
Brazlândia Rosada & rosada & creme escuro \\
Santa Sofia & rosada & creme escuro \\
CNPH 29 & rosada & creme \\
Georgia Improved & creme & creme \\
Balão & creme & creme \\
CNPH 53 & roxa & creme \\
Batata Africana 1 & rosada & creme \\
Batata Correntina $\mathrm{n}^{\circ} 24$ & rosada & creme \\
CNPH 71 & creme escuro & creme \\
\hline
\end{tabular}

Coloração baseada em escala de notas proposta por Kalkmann (2011).

De acordo com Kalkmann (2011) o genótipo CNPH 53 apresenta teores de antocianina em sua composição o que confere à pigmentação arroxeada de sua casca. Essa substância tem múltiplas funções, dentre outras, uma intensa atividade antioxidante, antimutagênica, efeito anti-hiperglicêmico e efeitos hepatoprotetivos e anti-hipertensivos.

Oliveira et al. (2002), estudaram a variabilidade genética em batata-doce e avaliaram 55 genótipos compreendendo cultivares comerciais e genótipos obtidos em coletas em várias regiões brasileiras. Alguns dos genótipos observados apresentaram a mesma coloração de casca e polpa que os tratamentos analisados neste estudo: 1 (Casca creme e polpa creme), 28 (casca rosada e polpa creme) e 45 (casca roxa e polpa creme).

Resende et al. (2012), no Campo Experimental de Bebedouro da Embrapa Semiárido em Petrolina (PE), avaliaram genótipos regionais e genótipos provenientes da Embrapa Hortaliças. Os genótipos Vitória e Renova apresentaram casca roxa e polpa creme, e os genótipos CNPH 422-9 e CNPH 792-3 apresentaram a casca rosada e polpa creme. Pode-se observar que os genótipos citados tem semelhança na coloração da casca e polpa com os tratamentos CNPH 29, Batata Africana 1, Batata Correntina $\mathrm{n}^{\circ} 24$ e CNPH 53 respectivamente, analisados no presente trabalho. 
Nunes et al. (2012), testando genótipos provenientes do Banco de Germoplasma da Embrapa Hortaliças, nas condições de solo dos Tabuleiros Costeiros de Sergipe, constataram que os genótipos 1199 e 1189 possuem a casca creme e polpa creme e o 1229 possui casca roxa e polpa creme, similarmente aos genótipos Princesa, Georgia Improved, Balão e CNPH 53 avaliados no presente estudo.

Kalkmann (2011), também desenvolveu um estudo com genótipos oriundos da Embrapa Hortaliças, nas condições do cerrado do planalto central, na Fazenda Água Limpa pertencente a Universidade de Brasília (DF) e observou as seguintes colorações de casca e polpa: CNPH 1206 (casca creme e polpa creme); CNPH 1230 e Rainha (casca rosada e polpa creme escuro); CNPH 1190, CNPH 1199, CNPH 1229, CNPH 1200 e CNPH 1232 (casca rosada e polpa creme); CNPH 1187, CNPH 1225, CNPH 1198, CNPH 1231 e CNPH 1234 (casca roxa e polpa creme); CNPH 1209 (casca creme escuro e polpa creme). Esse resultado observado é semelhante a todas as colorações de casca e polpa apresentadas pelos tratamentos analisados neste estudo.

As possíveis divergências na coloração da casca e polpa entre genótipos idênticos aos utilizados nesse estudo podem ser devido à escala de cores utilizada e também da percepção de cores do avaliador em questão.

Conforme Miranda et al. (1995), as raízes comercializadas nos grandes centros urbanos apresentam coloração de polpa branca ou amarela. Assim, geralmente as raízes tuberosas consideradas de boa aparência são as que apresentam estas colorações.

A cor da polpa e da casca varia de acordo com a localidade, o produtor deve escolher aquela que seja mais aceita no mercado onde será comercializada a produção. Além disso, em cada região produtora existem variedades locais, cujo material de reprodução é permutado entre produtores (SILVA, et al., 2008).

Em testes realizados em Porteirinha (MG) a cultivar local mais consumida era a denominada de Paulistinha. Na região de Distrito Federal e entorno a variedade Brazlândia Roxa é a mais cultivada. Na região de Anápolis (GO) é cultivada uma variedade de pele roxa e polpa amarela, denominada de Rainha, muito bem aceita nos mercados regionais (SILVA, et al., 2008).

Apesar de haver diferença significativa entre os genótipos quanto ao teor de sólidos solúveis totais (SST) pelo teste de F, as médias não diferiram entre os tratamentos, segundo o teste Scott-Knott. As demais características apresentaram diferenças significativas no teste de médias (tabela 7). 
Tabela 7 - Médias dos teores de sólidos solúveis totais, acidez total titulável, ratio, rendimento de amido e umidade das raízes dos genótipos avaliados. FAV/UnB, 2015.

\begin{tabular}{cccccc}
\hline $\begin{array}{c}\text { Genótipos do } \\
\text { BAG }\end{array}$ & $\begin{array}{c}\text { Umidade } \\
(\boldsymbol{\%}) * *\end{array}$ & $\begin{array}{c}\text { Amido } \\
(\boldsymbol{\%}) * *\end{array}$ & $\begin{array}{c}\text { ATT } \\
(\boldsymbol{\%}) *\end{array}$ & $\begin{array}{c}\text { SST } \\
\left({ }^{\circ} \mathbf{b r i x}\right) *\end{array}$ & Ratio* $^{*}$ \\
\hline Princesa & $70,18 \mathrm{a}$ & $11,38 \mathrm{a}$ & $4,15 \mathrm{~b}$ & $10,83 \mathrm{a}$ & $2,63 \mathrm{~b}$ \\
Brazlândia & $73,35 \mathrm{~b}$ & $8,84 \mathrm{~b}$ & $3,52 \mathrm{~b}$ & $11,25 \mathrm{a}$ & $3,29 \mathrm{~b}$ \\
Rosada & $74,01 \mathrm{~b}$ & $6,34 \mathrm{c}$ & $2,37 \mathrm{a}$ & $10,00 \mathrm{a}$ & $4,25 \mathrm{a}$ \\
Santa Sofia & $70,91 \mathrm{a}$ & $10,39 \mathrm{a}$ & $2,53 \mathrm{a}$ & $10,50 \mathrm{a}$ & $4,24 \mathrm{a}$ \\
CNPH 29 & $71,56 \mathrm{a}$ & $9,78 \mathrm{a}$ & $4,18 \mathrm{~b}$ & $11,00 \mathrm{a}$ & $2,71 \mathrm{~b}$ \\
Georgia & $71,73 \mathrm{a}$ & $7,99 \mathrm{~b}$ & $3,80 \mathrm{~b}$ & $11,62 \mathrm{a}$ & $3,16 \mathrm{~b}$ \\
Improved & $68,73 \mathrm{a}$ & $11,98 \mathrm{a}$ & $2,76 \mathrm{a}$ & $12,25 \mathrm{a}$ & $4,42 \mathrm{a}$ \\
Balão & $77,90 \mathrm{c}$ & $8,84 \mathrm{~b}$ & $3,35 \mathrm{~b}$ & $10,00 \mathrm{a}$ & $3,02 \mathrm{~b}$ \\
CNPH 53 & $77,32 \mathrm{c}$ & $8,63 \mathrm{~b}$ & $3,63 \mathrm{~b}$ & $10,87 \mathrm{a}$ & $3,29 \mathrm{~b}$ \\
Batata Africana 1 & $68,67 \mathrm{a}$ & $5,49 \mathrm{c}$ & $3,10 \mathrm{a}$ & $11,25 \mathrm{a}$ & $4,17 \mathrm{a}$ \\
Batata Correntina $\mathrm{n}^{\circ} 24$ & 72,44 & 8,97 & 3,34 & 10,96 & 3,52 \\
CNPH 71 & 2,46 & 14,37 & 21,56 & 8,27 & 23,00 \\
\hline Média & CV\% &
\end{tabular}

** Significativo a $1 \%$ pelo teste F. * Significativo a $5 \%$ pelo teste F. Médias seguidas pela mesma letra minúscula nas colunas não diferem entre si pelo teste "Scott-Knott", em nível de $5 \%$ ou $1 \%$ de probabilidade.

Estudando raízes de batata-doce na Universidade Estadual do Norte Fluminense Darcy Ribeiro (UNEF/RJ), Moulin (2010) verificou valores entre 5,20 e 25,0 ํix.

Segundo Carmona (2015), conduzindo um trabalho de resistência com 23 genótipos de batata-doce em Brasília (DF), em condições similares à deste trabalho, observou que a característica SST foi significativa a $1 \%$ de probabilidade e suas médias diferiam atingindo uma amplitude de 7,61 a $12,13{ }^{\circ}$ brix, muito semelhante ao constatado neste estudo. Alguns dos genótipos estudados por Carmona são os mesmos analisados neste trabalho: Brazlândia Rosada (9,90 ${ }^{\circ}$ brix), CNPH 29 (9,82 ${ }^{\circ}$ brix), Balão/CNPH 46 (9,22 ${ }^{\circ}$ brix), Batata Africana 1/ CNPH61 (9,77 ${ }^{\circ}$ brix) e CNPH 71 (12,13 brix). Todos genótipos obtiveram valores de SST inferiores comparados aos resultados observados no presente estudo, exceto o CNPH 71.

Kalkmann (2011), avaliando as características físico-químicas de 25 genótipos de batata-doce verificou que a característica SST não foi significativa e suas médias não diferiram entre si, variando de 0,87 a $1,97^{\circ}$ brix, sendo esses muito inferiores aos observados no presente estudo.

Berrones (2012) estudou dois genótipos de batata-doce no Equador, observou 10,4 `brix no genótipo de batata-doce de casca roxa e $10,0{ }^{\circ}$ brix no genótipo de batata-doce de casca rosada. Os dados apresentados no trabalho de Berrones são semelhantes os resultados do presente estudo. 
O teor de sólidos solúveis totais, geralmente expresso em ${ }^{\circ}$ brix, indica a quantidade de sólidos (açúcares) que se encontram dissolvidos no suco ou na polpa das frutas e hortaliças, influenciando na manutenção do sabor, aroma, cor e textura dos mesmos. Há a tendência de aumento dos SST com a maturação. Para a indústria, teores elevados, resultam em maior rendimento do produto final (KALKMANN, 2011).

A acidez teve uma amplitude de 2,37\% a 4,18\% no presente trabalho. Apenas $40 \%$ dos tratamentos foram superiores: Santa Sofia (2,37\%), CNPH 29 (2,53\%), CNPH 53 (2,76\%), CNPH 71 (3,10). Os demais materiais testados alcançaram uma porcentagem de acidez mais elevada e não se diferenciaram entre si, porém diferem dos genótipos citados (tabela 7).

O estudo de Berrones (2012) demonstrou acidez de 3,4 \% para um genótipo de batatadoce de casca roxa e 2,5\% para um genótipo de batata-doce de casca rosada. Os valores apresentados são semelhantes aos resultados observados no presente estudo.

Kalkmann (2011), também avaliou a acidez em genótipos de batata-doce e verificou a variação de $0,67 \%$ a $1,62 \%$, sendo esses dados inferiores aos observados no presente estudo.

Carmona (2015), também efetuou a análise da acidez em genótipos de batata-doce demonstrando valores de 2,00\% a 10,10\%. Dentre os genótipos analisados alguns são os mesmos que os estudados neste trabalho e foram observados os seguintes resultados: Brazlândia Rosada (6,88\%), CNPH 29 (7,74\%), Balão/CNPH 46 (7,02\%), Batata Africana 1/ CNPH61 (2,00\%) e CNPH 71 (4,69\%). Apenas os dois últimos genótipos observados por Carmona se aproximaram dos valores obtidos no presente trabalho, o restante alcançou valores superiores de porcentagem de acidez.

A acidez influencia na qualidade, na conservação e manutenção das características dos alimentos, podendo ser decorrente dos próprios compostos naturais do alimento, formada pela fermentação ou pelo tipo de processamento ao qual o alimento foi submetido, ou ainda, ser o resultado da deterioração que o mesmo sofreu (SANTOS et al., 2012). O aumento progressivo da acidez indica que as características originais da batata-doce estão sendo comprometidas.

A razão ratio (sólidos solúveis totais/acidez total titulável) desse estudo demonstrou os melhores resultados para os tratamentos CNPH $53(4,42)$, Santa Sofia $(4,25)$, CNPH 29 $(4,24)$ e CNPH $71(4,17)$, sendo todos semelhantes estatisticamente. Pode-se deduzir a partir dos dados observados que esses genótipos são os mais precoces dentre os estudados, pois o ratio indica o grau de maturidade da batata-doce no momento da colheita. Os genótipos Georgia Improved $(2,71)$ e Princesa $(2,63)$ demonstraram os menores valores de ratio, sendo 
os mais tardios, pois na época da colheita ainda apresentavam baixos teores de sólidos solúveis.

Carmona (2015) efetuou análises químicas em 23 genótipos de batata-doce em Brasília (DF) e constatou que a razão ratio variou de 0,76 a 4,97. No presente estudo foram observados valores que variaram de 2,63 a 4,42, estando contidos no intervalo obtido por Carmona.

Kalkmann (2011) em um estudo desenvolvido em Brasília (DF) examinou 25 genótipos de batata-doce e chegou a valores para a razão ratio que variaram de 0,49 a 2,07, indicando que os genótipos estudados provavelmente eram mais tardios comparados aos analisados no presente estudo.

O ratio é uma das melhores formas de avaliação do sabor e pode ser utilizado como índice de qualidade interna da polpa de batata-doce, em conjunto com outros parâmetros. Durante o processo de maturação seu valor tende a aumentar, em função da hidrólise do amido com aumento do teor de açúcares solúveis e devido à diminuição, nesse período, da acidez do fruto. Desta forma, quando se comparam frutos de diversos materiais genéticos colhidos na mesma época, os considerados mais precoces devem apresentar maior teor de sólidos solúveis, menor acidez e/ou maior ratio (KALKMANN, 2011).

No presente experimento a umidade variou de $68,67 \%$ a 77,90\%, sendo os genótipos CNPH 71 e Batata Africana 1 os que apresentaram a menor e a maior umidade, respectivamente. Os genótipos Princesa $(70,18)$ e CNPH $29(70,91)$ demonstraram teor de umidade de aproximadamente 70\%. Os tratamentos CNPH 53, Georgia Improved, Balão e CNPH 71 também apresentaram valores muito próximos de $70 \%$ de umidade, demonstrando uma diferença máxima superior ou inferior de $2 \%$ de umidade, sendo todos estatisticamente iguais. Os demais genótipos apresentaram umidades superiores, diferenciando-se entre si e dos genótipos citados anteriormente. Segundo Silva et al. (2008), ao ser colhida a batata doce apresenta cerca de $70 \%$ de umidade.

Kalkmann (2011), em análises físico-químicas de batata-doce verificou que a umidade variou entre $60,77 \%$ e 76,24 \%, estando esse intervalo bem próximo do observado no presente trabalho.

Carmona (2015) realizou análises químicas em seu estudo de resistência com batatadoce encontrando valores de umidade de 66,67 a 75,38\%. Dentre os genótipos estudados estão Brazlândia Rosada (69,03\%), CNPH 29 (70,64\%), Balão/CNPH 46 (72,71\%), Batata Africana 1/CNPH61 (66,65\%) e CNPH 71 (67,42\%), dos quais apenas dois apresentaram 
diferença maior que $1,5 \%$ de umidade com relação aos resultados encontrados no presente estudo, sendo bastante similares.

Roesler et al. (2008), com o objetivo de avaliar cultivares de batata-doce com aptidão para o processamento de fécula, no município de Marechal Cândido Rondon na região oeste do Paraná, constataram que a cultivar Brazlândia Rosada apresentou 74,20\% de umidade. Essa mesma cultivar obteve $73,35 \%$ de umidade no presente trabalho, valor semelhante ao encontrado pelo autor citado.

Leonel \& Cereda (2002), realizando a caracterização físico-química de algumas tuberosas amiláceas, no Campo Experimental do Centro de Raízes e Amidos Tropicais da UNESP (SP), observaram que a cultura da batata-doce apresentou $67,73 \%$ de umidade. Esse valor é similar aos demonstrados pelos genótipos CNPH 71 (68,67\%) e CNPH 53 (68,73\%) estudados no presente trabalho.

Os genótipos CNPH 53 (11,98\%), Princesa (11,38\%), CNPH 29 (10,39\%) e Georgia Improved $(9,78 \%)$ se destacaram como os mais promissores obtendo as maiores porcentagens de amido, enquanto os genótipos CNPH 71 (5,49\%) e Santa Sofia $(6,34 \%)$ demonstraram os menores teores. Os demais tratamentos alcançaram porcentagens intermediárias não diferindo entre si, porém são estatisticamente diferentes dos já citados (tabela 7).

Leonel \& Cereda (2002), estudando tuberosas amiláceas, no Campo Experimental do Centro de Raízes e Amidos Tropicais da UNESP (SP), observaram que a cultura da batatadoce obteve $14,72 \%$ de amido. Esse teor de amido é próximo ao encontrado para o genótipo de maior rendimento no presente estudo, o CNPH 53 (11,98\%), apresentando uma diferença de apenas $2,74 \%$.

Kalkmann (2011) verificou em seu estudo que o rendimento de amido variou de $3,87 \%$ a $17,32 \%$, estando esses valores próximos do intervalo observado no presente trabalho.

Os teores mais baixos de umidade são desejáveis às batatas-doces de mesa, uma vez que a preferência do consumidor é por raízes que apresentem polpa seca após o cozimento. As indústrias têm interesse em variedades que apresentem maior teor de matéria seca, pois potencialmente terá maior teor de fécula e melhor extração, ao mesmo tempo em que deverá gerar menor quantidade de água residual. Sob esse ponto de vista, a batata-doce leva vantagem em relação às tuberosas mais comuns, pois apresenta maior teor de matéria seca, aproximadamente 68\% (KALKMANN, 2011). 
A herdabilidade dos caracteres estudados foi estimada com base na média das parcelas (tabela 8). Embora sejam observadas estimativas de herdabilidade relativamente altas, nem todos os caracteres estudados apresentaram uma variabilidade genética grande o suficiente para sensíveis ganhos genéticos por meio de seleção, como por exemplo, a variável comprimento das raízes. A variável produtividade total estimada não expressou valores significativos (tabela 8). Os demais valores de herdabilidade foram altos e refletem pouca ou moderada influência do ambiente na seleção, podendo existir ganhos genéticos consideráveis. A razão $\mathrm{CVg} / \mathrm{CVe}$ foi menor que 1 para a maioria das variáveis analisadas, indicando uma condição desfavorável para seleção, pois o efeito da variância ambiental é maior que o observado para a variância genética.

As variáveis produtividade comercial estimada, umidade e amido apresentaram valores de $\mathrm{h}_{\mathrm{a}}{ }^{2}$ e razão $\mathrm{CVg} / \mathrm{CVe}$ de $91,87 \%$ e 1,$68 ; 92,39 \%$ e 1,74; 90,07\% e 1,51; respectivamente (tabela 8). As três variáveis mencionadas demonstraram valores de herdabilidade acima de $90 \%$ e maiores que 1 para a razão $\mathrm{CVg} / \mathrm{CVe}$, indicando condição favorável para seleção, demonstrando que houve pouca influência da variância ambiental.

Kalkmann (2011) estudando 25 progênies de batata-doce no Distrito Federal, no qual avaliou a produtividade comercial, umidade e amido, verificou herdabilidade e a razão $\mathrm{CVg} / \mathrm{CVe}$ de $87,25 \%$ e 1,$31 ; 85,57 \%$ e 1,$22 ; 81,94 \%$ e 1,07 para essas características, respectivamente.

Resultados semelhantes foram apresentados por Carmona (2015), estudando a divergência genética de 23 genótipos de batata-doce em Brasília para as variáveis produtividade comercial, umidade e amido, encontrando herdabilidade e razão $\mathrm{CVg} / \mathrm{CVe}$ de $81,55 \%$ e 1,$05 ; 82,78 \%$ e 1,$1 ; 83,3 \%$ e 1,12 ; respectivamente.

Os genótipos analisados no presente estudo podem ser selecionados com sucesso para as características produtividade comercial estimada, umidade, amido, pois seus valores de herdabilidade e a razão entre o coeficiente de variação genético e ambiental foram os maiores observados dentre todas as estimativas realizadas, sendo bastante herdáveis.

As características número de furos, formato, acidez e ratio apresentaram valores de herdabilidade entre $60 \%$ e $70 \%$ aproximadamente e razão $\mathrm{CVg} / \mathrm{CVe}$ em torno de 0,7 , sendo os mesmos iguais a $71,00 \%$ e 0,$78 ; 69,76 \%$ e 0,$76 ; 68,32 \%$ e 0,$73 ; 64,99 \%$ e 0,68 ; respectivamente (tabela 8 ). 
Gonçalves Neto et al. (2012), em Ijaci (MG) encontrou herdabilidade muito próxima da observada no presente estudo para a variável formato correspondente a $66,86 \%$, porém a razão $\mathrm{CVg} / \mathrm{CVe}$ encontrada foi superior e igual a 1,04.

Viana (2009), estudando genótipos de batata doce em Diamantina (MG) encontrou $50,12 \%$ de herdabilidade para o formato.

Kalkmann (2011), estudando 25 genótipos de batata-doce no Distrito Federal avaliou as características acidez e ratio obtendo valores de herdabilidade correspondentes a 69,10\% e $50,74 \%$ e valores para a razão $\mathrm{CVg} / \mathrm{CVe}$ de 0,75 e 0,51 ; respectivamente.

Carmona (2015) em seu trabalho de divergência genética com genótipos de batatadoce em Brasília estudou a variável número de furos e a mesma apresentou $\mathrm{h}_{\mathrm{a}}{ }^{2}$ de $59,00 \%$ e razão $\mathrm{CVg} / \mathrm{CVe}$ de 0,60 ; valores esses menores que os observados no presente trabalho.

Apesar de não apresentarem valores de herdabilidade tão altos as variáveis número de furos, formato, acidez e ratio podem ser consideradas no processo de seleção, pois segundo Bourdon (1997) características com valores de herdabilidade acima de 40\% são bastante herdáveis. Contudo, seus valores para a razão $\mathrm{CVg} / \mathrm{CVe}$ se mostraram menores que 1 apontando que há considerável influência ambiental sobre tais características.

Com relação a espessura da casca, incidência de danos e SST os valores de herdabilidade se mostram abaixo de $60 \%$ e a razão $\mathrm{CVg} / \mathrm{CVe}$ menor que 0,6 . Os valores obtidos para essas variáveis foram de $44,82 \%$ e 0,$45 ; 56,27 \%$ e 0,$57 ; 57,57 \%$ e 0,58 , respectivamente (tabela 8 ).

Cavalcante et al. (2009), avaliando dez caracteres de batata-doce em Maceió (AL), encontrou valores próximos aos demonstrados no presente estudo para a característica espessura da casca, identificando uma herdabilidade de $66,20 \%$ e razão CVg/CVe de 0,8 para essa variável.

Segundo Carmona (2015), em experimento com batata-doce em Brasília obteve uma herdabilidade de 65,76\% e CVg/CVe de 0,69 para a incidência de danos. Kalkmann (2011), verificou que a herdabilidade para essa mesma característica foi de $44,86 \%$ e a $\mathrm{CVg} / \mathrm{CVe}$ foi de 0,45 .

Os valores de herdabilidade e a razão CVg/CVe para a variável SST observada nesse estudo apresentou valor intermediário aos encontrados nos trabalhos de Kalkmann (2011) e Carmona (2015), sendo de $27,78 \%$ e 0,$31 ; 80,71 \%$ e 1,02 ; respectivamente.

Apesar de Bourdon (1997) afirmar que características com valores de herdabilidade acima de $40 \%$ são bastante herdáveis, os baixos valores de herdabilidade observados no 
presente estudo para as características espessura da casca, incidência de danos e SST devem ser analisados atentamente durante o processo de seleção. Além disso, a razão CVg/CVe das variáveis se mostraram menores que 1 apontando que a seleção não será efetiva, uma vez que a variância genética foi inferior a ambiental.

O comprimento das raízes apresentou baixo valor de herdabilidade correspondente a 2,66\% e razão $\mathrm{CVg} / \mathrm{CVe}$ de 0,08 ; demonstrando ser uma característica pouco herdável (tabela 8). Valores baixos como esses indicam que a variância ambiental superou a genotípica, não sendo prudente efetuar o processo de seleção empregando métodos simples de melhoramento, pois não proporcionarão ganhos expressivos. O emprego de métodos de melhoramento baseados no desempenho de famílias é mais adequado do que aqueles que utilizam a seleção com base no desempenho de plantas individuais.

O comprimento de raízes foi estudado por Cavalcante et al. (2009), em uma avaliação de genótipos de batata-doce em Maceió (AL), identificando herdabilidade correspondente a $64,37 \%$ e a razão $\mathrm{CVg} / \mathrm{CVe}$ de 0,78 ; bem superior ao presente trabalho. 
Tabela 8 - Estimativas da herdabilidade no sentido amplo $\left(\mathrm{h}_{\mathrm{a}}{ }^{2}\right)$, coeficiente de variação genético $\left(\mathrm{CV}_{\mathrm{g}}\right)$ e razão entre coeficiente de variação genético e ambiental $\left(\mathrm{CV}_{\mathrm{g}} / \mathrm{CV}_{\mathrm{e}}\right)$ de 13 variáveis avaliadas para 10 genótipos de batata-doce em campo no Distrito Federal. FAV/UnB, 2015.

\begin{tabular}{|c|c|c|c|c|c|c|c|c|c|c|c|c|}
\hline $\begin{array}{l}\text { Parâmetros } \\
\text { Genéticos }\end{array}$ & PTE & PCE & COMP & ESPC & NF & ID & FORM & UMID & AMID & ATT & SST & RATIO \\
\hline $\mathrm{CV}_{\mathrm{g}}(\%)$ & - & 64,87 & 1,73 & 9,49 & 34,89 & 10,92 & 19,80 & 4,28 & 21,65 & 15,80 & 4,82 & 15,68 \\
\hline
\end{tabular}

PTE: produtividade total estimada da parcela (t/ha); PCE: produtividade comercial estimada da parcela (t/ha); COMP: comprimento das raízes da parcela (mm); ESPC: espessura da casca das raízes da parcela $(\mathrm{mm})$; NF: número de furos nas raízes; ID: nota para incidência de danos causados por insetos de solo; FORM: nota para formato da raiz; UMID: umidade da polpa das raízes (\%); AMID: rendimento de amido das raízes (\%); ATT: acidez total titulável da raiz (\%); SST: teor de sólidos solúveis totais da polpa das raízes ( ${ }^{\circ}$ brix); RATIO: razão entre os valores de sólidos solúveis totais e acidez total titulável, adimensional. 


\section{CONCLUSÕES}

Os genótipos CNPH 53 e Santa Sofia foram os mais produtivos, enquanto os genótipos Brazlândia Rosada e Santa Sofia se destacaram em produtividade comercial estimada.

Sessenta por cento dos genótipos (CNPH 71, Georgia Improved, Balão, CNPH 53, Batata Africana 1 e Batata Correntina $n^{\circ}$ 24) se classificaram como moderadamente suscetíveis.

A espessura da casca apresentou os maiores valores para os genótipos Brazlândia Rosada e Batata africana 1.

O genótipo CNPH 29 se destacou com o melhor resultado, sendo que o comprimento de $80 \%$ dos genótipos observados mantiveram-se dentro da faixa de comprimento considerada ideal (120 a $160 \mathrm{~mm})$.

Noventa por cento dos tratamentos apresentaram raízes de formato excelente e bom, destacando-se os genótipos Georgia Improved e Santa Sofia.

O genótipo CNPH 71 apresentou cor da casca creme escuro e o genótipo CNPH 53 cor da casca roxa, 30\% dos genótipos demonstrou cor da casca creme e 50\% cor da casca rosada. Oitenta por cento teve cor da polpa creme e $20 \%$ polpa creme escuro.

O genótipo CNPH 53 apresentou o maior teor de sólidos solúveis, demonstrando maior grau de maturação no momento da colheita que os demais genótipos.

Os genótipos Santa Sofia, CNPH 29, CNPH 53 e CNPH 71 apresentaram os melhores resultados em relação à acidez e ratio, demonstrando maior precocidade dentre os genótipos estudados.

Os genótipos Princesa e CNPH 29 apresentaram teores de umidade próximos de 70\%, considerado normal no momento da colheita.

Os genótipos CNPH 53, Princesa, CNPH 29 e Georgia Improved foram os mais promissores quanto ao teor de amido.

As estimativas de herdabilidade foram relativamente altas, porém nem todos os caracteres estudados apresentaram variabilidade genética grande o suficiente para sensíveis ganhos genéticos por meio de seleção. Apenas a produtividade comercial estimada, umidade e amido obtiveram valores de herdabilidade acima de $90 \%$ e valores da razão $\mathrm{CVg} / \mathrm{CVe}$ maiores que 1, indicando suficiente diversidade genética para seleção e obtenção de progresso genético mesmo com a utilização de métodos de seleção simples, como a seleção massal. 


\section{REFERÊNCIAS BIBLIOGRÁFICAS}

AZEVEDO A. M.; ANDRADE JÚNIOR, V. C.; FERNANDES, J. S. C.; PEDROSA, C. E.; OLIVEIRA, C. M. Desempenho agronômico e parâmetros genéticos em genótipos de batatadoce. Horticultura Brasileira. v. 33, n.1, p. 084-090, DOI - http://dx.doi.org/10.1590/S0102053620150000100014 , Jan. - mar. 2015.

BERRONES, F. S. B. Hidrólisis enzimática del almidón residual em extractos líquidos de camote (Ipomoea batatas L.), para elaboración de miel y estúdio de sus propriedades funcionales. Proyecto prévio a la obtención del título de ingeniero agroindustrial. Escuela Politécnica Nacional. Quito, Ecuador, 147 p., 2012.

BOURDON, R. M. Understanding animal breeding. New Jersey: Prentice Hall, p.523, 1997.

CARMONA, P. O. Caracterização morfoagronômica, físico-química e tolerância ao nematoide-das-galhas de genótipos de batata-doce avaliados no Distrito Federal. Tese (Doutorado em Agronomia), Faculdade de Agronomia e Medicina Veterinária - FAV, Universidade de Brasília - UnB, Brasília, 227 f. :il., 2015.

CARMONA, P. O.; PEIXOTO, J. R.; AMARO, G. B.; MENDONÇA, M. A. Divergência genética entre acessos de batata-doce utilizando descritores morfoagronômicos das raízes. Horticultura Brasileira. v. 33, n. 2, p. 241-250, DOI - http://dx.doi.org/10.1590/S0102053620150000200017 , Abr. - jun. 2015.

CARVAlHO, C.; KIST, B. B.; POLL, H. Anuário Brasileiro de Hortaliças. Rio Grande do Sul, Santa Cruz do Sul: Editora Gazeta Santa Cruz, 88 p.: il., 2013.

CAVALCANTE, M.; FERREIRA, P. V., PAIXÃO, S. L.; COSTA, J. G. DA; PEREIRA, R. G.; MADALENA, J. A. S. Potenciais produtivo e genético de clones de batata-doce. Acta Scientiarum Agronomy. Maringá, v. 31, n. 3, p. 421-426, DOI: 10.4025/actasciagron.v31i 3.835, 2009.

CRUZ, C.D. Programa Genes: aplicativo computacional em genética e estatística. Viçosa: Editora UFV, 442 p., 1997.

FRANÇA, F.H.; MIRANDA, J.E.C.; FERREIRA, P.E.; BARBOSA, S. Avaliação de germoplasma de batata-doce (Ipomoea batatas (L.) Lam.), visando resistência a insetos de solo. In: Congresso Brasileiro de Olericultura, 23., Rio de Janeiro, 1983. Resumos... Rio de Janeiro, SOB, p.177., 1983.

FERREIRA, P. V. Coleção Melhoramento de Plantas. Métodos de Melhoramento. Maceió: EDUFAL, v. 5, il., 2006.

FERREIRA, D. F. Análises estatísticas por meio do SISVAR para Windows. Versão 4.0. In: Reunião anual da região brasileira da sociedade internacional de biometria. Programas e Resumos... São Carlos (SP): UFSCar, 235p., 2000. 
GONÇALVES NETO, A. C.; MALUF, W.R.; GOMES, L. A. A.; MACIEL, G. M.; FERREIRA, R. P. D.; CARVALHO, R. C. Correlação entre caracteres e estimação de parâmetros populacionais para batata-doce. Horticultura Brasileira. v. 30, n. 4, p. 713-719, out - dez. 2012.

IBGE - INSTITUTO BRASILEIRO DE GEOGRAFIA E ESTATÍSTICA. Produção Agrícola Municipal. Culturas temporárias e permanentes. Áreas plantada e colhida, quantidade produzida, rendimento médio e valor da produção dos principais produtos das lavouras temporárias, segundo as Grandes Regiões e Unidades da Federação produtoras. Rio de Janeiro, v. 39, p. 1-101, 2012. Disponível em: <http://www.ibge.gov.br/home/estatistica/pesquisas/pesquisa_resultados.php?id_pesquisa=4. Acesso em: 29 de maio de 2014.

INSTITUTO ADOLFO LUTZ. Normas Analíticas do Instituto Adolfo Lutz. Métodos químicos e físicos para análise de alimentos, 4. ed. São Paulo: IMESP, 1018p., 2005.

KALKMANN, D. C. Produtividade, qualidade de raiz, resistência aos insetos de solo e aos nematoides de galhas, e estimativas de parâmetros genéticos em clones de batatadoce cultivados no Distrito Federal. Dissertação (Mestrado em Agronomia), Faculdade de Agronomia e Medicina Veterinária - FAV, Universidade de Brasília - UnB, Brasília, 144 p., 2011.

LEONEL, M \& CEREDA, M. P. Caracterização físico-química de algumas tuberosas amiláceas. Ciênc. Tecnol. Aliment., Campinas, v. 22, n. 1, p. 65-69, jan.-abr. 2002.

MASSAROTO, J.A. Características agronômicas e produção de silagem de clones de batata-doce. Tese (Doutorado em Fitotecnia) - Universidade Federal de Lavras, Lavras - MG, 2008 .

MIRANDA, J.E.C.; FRANÇA, F.H.; CARRIJO, O.A.; SOUZA, A.F.; PEREIRA, W.; LOPES, C.A.; SILVA, J.B.C. A cultura da batata-doce. Empresa Brasileira de Pesquisa Agropecuária, Centro Nacional de Pesquisa de Hortaliças - Brasília: Embrapa - SPI, Coleção Plantar, 1995.

MOULIN, M. M. Coleta, caracterização e conservação de variedades locais de batatadoce (Ipomoea batatas L. Lam) do norte do estado do Rio de Janeiro. Dissertação (mestrado em Genética e Melhoramento de Planatas), Universidade Estadual do Norte Fluminense Darcy Ribeiro - UENF, Rio de Janeiro, 2010.

NUNES, M. U. C; JESUS, A. F.; LIMA, I.S.; SANTOS, L.S.; CRUZ, D. P. Produtividade de genótipos de batata-doce com diferentes colorações de raízes em cultivo orgânico. Horticultura Brasileira, v. 30, n. 2, S5542-S5548, Suplemento - CD Rom, Julho 2012.

OLIVEIRA, A. C. B.; SEDIYAMA, M. A. N.; SEDIYAMA, T.; FINGER, F. L.; CRUZ, C. D. Variabilidade genética em batata-doce com base em marcadores isoenzimáticos. Horticultura Brasileira, Brasília, v. 20, n. 4, p. 576-582, dezembro 2002.

PEIXOTO, J. R.; SANTOS, L. C.; RODRIGUES, F. A.; JULIATTI, F. C.; LYRA, J. R. M. Seleção de clones de batata-doce resistentes a insetos de solo. Pesquisa Agropecuária Brasileira. Brasília, v. 34, n. 3, p. 385-389. Março, 1999. 
RESENDE, G. M. de; COSTA, N. D.; YURI JE; MOTA, J. H. Desempenho de clones de batata-doce (Ipomoea batatas L.) no Submédio Vale do São Francisco. Horticultura Brasileira v. 30, n. 2, S3241-S3247, Suplemento - CD Rom, Julho 2012.

ROESLER, P. V. S. O.; GOMES, S. D.; MORO, E.; KUMMER, A. C. B.; CEREDA, M. P. Produção e qualidade de raiz tuberosa de cultivares de batata-doce no oeste do Paraná. Acta Sci. Agron. Maringá, v. 30, n. 1, p. 117-122, 2008.

SANTOS, J. C.; SOUZA, D. C. L.; SANTANA, M. M. DE; CASTRO, A. A.; SILVA, G. F. Estudo da cinética de secagem de batata-doce (Ipomoea batatas). Revista Brasileira de Produtos Agroindustriais. Campina Grande, v.14, n.4, p.323-328, ISSN 1517-8595, 2012.

SCHRAMMEL, P. Desempenho agronômico de clones de batata-doce em condições de campo. Trabalho de conclusão de curso (Agronomia), Faculdade de Agronomia e Medicina Veterinária - FAV, Universidade de Brasília - UnB, Brasília, 42 p., 2011.

SILVA, J. B. C.; LOPES, C. A.; MAGALHÃES, J. S. Cultivo da batata-doce. Brasília: EMBRAPA-CNPH, Sistemas de Produção 6, ISSN 1678-880X Versão Eletrônica, Junho 2008.

VIANA, D. J. S. Produção e qualidade de raízes, ramas e silagem de ramas de clones de batata-doce em diferentes locais e épocas de colheita. Dissertação (Produção Vegetal). Faculdade de Ciências Agrárias, Universidade Federal dos Vales do Jequitinhonha e Mucuri UFVJM. Diamantina, 69p., 2009.

ZAVARESE, E.R.; STORCK, C.R.; PEREIRA, J.M. Elaboração de pão de queijo com substituição do amido de mandioca por amido de batata-doce (Ipomoea batatas) submetido a diferentes processos de secagem. Brazilian Jounal of Food Technology, v. 12, n. 1, p. 6876, jan./mar, 2009. 


\section{CAPÍTULO II}

RESISTÊNCIA DE CLONES DE BATATA-DOCE AOS NEMATOIDES DAS GALHAS (Meloidogyne spp.) 


\section{RESISTENNCIA DE CLONES DE BATATA-DOCE AOS NEMATOIDES DAS GALHAS (Meloidogyne spp.)}

\section{RESUMO}

A identificação de cultivares resistentes a nematoides é estratégico para todas as culturas agrícolas, sendo uma medida mais eficaz, econômica e ecológica de controle. A utilização de nematicidas e inseticidas de solo na cultura da batata-doce não tem sido recomendada por ser ineficiente e antieconômica. Contudo, a utilização de germoplasmas de batata-doce resistentes ao nematoide das galhas tem sido possível, constituindo-se uma importante alternativa de controle. O objetivo deste trabalho foi caracterizar a resistência de 10 genótipos de batata-doce aos nematoides das galhas Meloidogyne incognita e Meloidogyne paranaensis. Os genótipos avaliados foram oriundos do Banco de Germoplasma da Embrapa Hortaliças (CNPH) e mantidos num jardim clonal na Fazenda Água Limpa da Universidade de Brasília (UnB). Foram instalados dois ensaios, um para cada espécie de Meloidogyne, com o delineamento experimental de blocos casualizados em arranjo simples, com 10 tratamentos, 3 repetições, 5 plantas de batata-doce/parcela para a espécie Meloidogyne incognita e 3 plantas de batata-doce/parcela para a espécie Meloidogyne paranaensis. Foram avaliados 10 genótipos: Princesa (CNPH 3), Roxinha (CNPH 5), Brazlândia Rosada (CNPH 9), Georgia Improved (CNPH 31), Balão (CNPH 46), CNPH 53, Batata Africana 1 (CNPH 61), Batata Correntina $\mathrm{n}^{\circ} 24$ (CNPH 66), CNPH 80, Palmeira (CNPH 1796). As características analisadas foram: peso da massa fresca da parte aérea, peso da massa seca da parte aérea, peso da massa fresca da raiz, número de ovos por parcela, número de ovos por planta, número de ovos por grama de raiz, número de massas de ovos, fator de reprodução e grau de resistência. No ensaio com Meloidogyne incognita o genótipo CNPH 53 foi o mais promissor para a massa fresca da parte aérea $(14,33 \mathrm{~g})$, o genótipo Georgia Improved se destacou para a massa seca da parte aérea (4,33 g) e o genótipo Brazlândia Rosada para a massa fresca de raiz (12,64 g). Todos os genótipos estudados apresentaram-se resistentes com base na análise do fator de reprodução, porém em relação ao número de massas de ovos esses mesmos genótipos se mostraram todos suscetíveis. No ensaio com Meloidogyne paranaensis o genótipo CNPH 53 se mostrou mais vigoroso tanto com relação à massa fresca da parte aérea (26,39 g), quanto para a massa seca da parte aérea $(5,83 \mathrm{~g})$, enquanto que os genótipos Brazlândia Rosada $(16,11 \mathrm{~g})$ e Batata Correntina $\mathrm{n}^{\mathrm{o}} 24(15,00 \mathrm{~g})$ se destacaram para a massa fresca de raiz. $\mathrm{O}$ genótipo CNPH 80 demonstrou-se resistente, com relação ao número de massas de ovos, 
sendo os demais tratamentos todos suscetíveis. Somente os genótipos CNPH 80, Georgia Improved, Balão, Princesa e CNPH 53 demonstraram resistência quanto ao fator de reprodução, ao passo que o restante dos genótipos foram todos suscetíveis. O genótipo CNPH 80 foi o único que demonstrou resistência ao M. paranaensis tanto em relação ao fator de reprodução, quanto ao número de massas de ovos.

Palavras-chave: doença, estacas, Ipomoea, nematoide das galhas, resistência. 


\section{CLONES OF RESISTANCE OF SWEET POTATO TO ROOT-KNOT NEMATODES (Meloidogyne spp.)}

\section{ABSTRACT}

The identification of resistant cultivars is strategic for all crops, being more efficient, economical and ecological means of control. The use of nematicides and soil pesticides in the culture of sweet potato has not been recommended for being inefficient and uneconomic. However, the use of sweet potato germplasm resistant to root-knot nematodes have been possible, and this is an important control alternative. The objective of this study was to characterize the resistance of 10 sweet potato genotypes to root-knot nematodes Meloidogyne incognita and Meloidogyne paranaensis. The evaluated genotypes were derived from the Germplasm Bank of Embrapa Vegetables (CNPH) and kept in a clonal garden at Fazenda Água Limpa the University of Brasilia (UnB). There were established two experiments, one for each species of Meloidogyne, with the randomized blocks in simple arrangement, with 10 treatments, 3 repetitions, 5 plants of sweet potato/share to Meloidogyne incognita and 3 plants of sweet potato/share for Meloidogyne paranaensis. We evaluated 10 genotypes: Princesa (CNPH 3), Roxinha (CNPH 5), Brazlândia Rosada (CNPH 9), Georgia Improved (CNPH 31), Balão (CNPH 46), CNPH 53, Batata Africana 1 (CNPH 61), Batata Correntina $n^{\circ} 24$ (CNPH 66), CNPH 80 and Palmeira (CNPH 1796). The analyzed characteristics were: weight of shoot fresh mass, weight of shoot dry mass, weight of root fresh mass, number of eggs per share, number of eggs per plant, eggs per gram of root, number of egg masses, reproduction factor and degree of resistance. In the experiment with $M$. incognita the genotype CNPH 53 was the most promising for weight of shoot fresh mass $(14,33 \mathrm{~g})$, the genotype Georgia Improved stood out to the weight of shoot dry mass $(4,33 \mathrm{~g})$ and the genotype Brazlândia Rosada had the best performance for weight of root fresh mass (12,64 g). All genotypes studied showed resistant based on the analysis of the reproduction factor, but in relation to the number of egg masses these same genotypes all showed susceptible. In the experiment with Meloidogyne paranaensis the genotype CNPH 53 showed the strongest both in relation to weight of shoot fresh mass $(26,39 \mathrm{~g})$, as for weight of shoot dry mass $(5,83 \mathrm{~g})$, while the genotype Brazlândia Rosada (16,11 g) and Batata Correntina $\mathrm{n}^{\mathrm{o}} 24(15,00 \mathrm{~g})$ stood out to weight of fresh root mass. The genotype CNPH 80 showed resistant with respect to the mass number of eggs, and all other susceptible. The genotypes CNPH 80, Georgia Improved, Balão, Princesa and CNPH 53 were resistant in relaction to the reproduction factor, while the 
remainder were susceptible. The genotype CNPH 80 was the only one that demonstrated resistance to $M$. paranaensis both on the reproduction factor, as the number of egg masses.

Keywords: disease, cuttings, Ipomoea, root-knot nematodes, resistance. 


\section{INTRODUÇÃO}

Os nematoides pertencem ao Filo Nematoda, são animais que se assemelham a vermes cilíndricos. A palavra nematoide é de origem grega onde nema significa "fio" e oide significa "em forma de", portanto a palavra nematoide corresponde a animais em forma de fio. São organismos tipicamente fusiformes, não segmentados, essencialmente aquáticos e que apresentam hábitat diversificado, sendo encontrados nas águas marinhas, águas doces e películas de água do solo. De acordo com a forma de alimentação, podem ser de vida livre, parasitas de animais ou parasitas de plantas (NAVES, 2005).

O aumento da produtividade agrícola tem-se tornado o objetivo primordial do melhoramento genético de plantas, como consequência da grande necessidade de uma fonte adequada de alimentação para satisfazer o constante crescimento da população humana. Contudo, esse aumento da produtividade agrícola será conseguido tanto pelo desenvolvimento de variedades altamente produtivas, quanto pelo desenvolvimento de variedades que contribuam para estabilizar a produção, destacando-se, entre outros fatores, a resistência a doenças (FERREIRA, 2006).

As doenças que ocorrem nas plantas são provocadas por microrganismos, denominados patógenos (bactérias, fungos, vírus e nematoides), os quais causam relevantes prejuízos às culturas. Tais prejuízos podem incidir sobre a quantidade, qualidade e custo da produção (FERREIRA, 2006).

O uso de variedades resistentes é o método ideal de controlar as doenças, portanto todos os outros métodos de controle aumentam o custo de produção, além de, em muitos casos não serem acessíveis à maioria dos agricultores. Ainda, em alguns casos se constitui no único método satisfatório de controle (FERREIRA, 2006).

Sendo assim, fica clara a importância do melhoramento de plantas visando à resistência a doenças, pois o uso de variedades resistentes, além de exercer um papel estabilizador da produção, contribui para minimizar a aplicação de produtos químicos (fungicidas, bactericidas etc.), reduzindo com isso o custo de produção e evitando uma agressão ao meio ambiente (FERREIRA, 2006).

Dentre as doenças mais importantes, a ocorrência de nematoides das galhas Meloidogyne spp. danifica as raízes causando a morte de plantas. No Brasil as espécies de nematoides que causam mais danos em cultivos de batata-doce são $M$. incognita e $M$. javanica. As espécies $M$. arenaria e $M$. hapla ocorrem com menor frequência nos campos de batata-doce. $\mathrm{Na}$ raiz tuberosa, dificilmente são observados sintomas de galhas, exceto em 
cultivares de elevada suscetibilidade, onde as galhas depreciam as raízes qualitativamente para comercialização e consumo (CHARCHAR \& RITSCHEL, 2004).

Ainda não há relatos da ocorrência de Meloidogyne paranaensis na cultura da batatadoce, contudo essa espécie foi detectada no Brasil pela primeira vez em plantas de café no estado do Paraná, podendo suprimir a produtividade em até $50 \%$. O M. paranaensis pode ocorrer por si só ou em populações mistas com outros Meloidogyne spp. Atualmente o nematoide foi detectado apenas nos EUA (incluindo Hawaii), América Central, Caribe, Guatemala e América do Sul (MOENS et al., 2009).

Os nematoides parasitas de plantas, chamados fitonematoides, alimentam-se principalmente de órgãos subterrâneos de plantas superiores, como raízes, rizomas, tubérculos, bulbos e frutos hipógeos, embora também existam outros que se alimentam de órgãos aéreos, como caules, folhas, flores, frutos e sementes (NAVES, 2005).

O controle dos nematoides das galhas em solos infestados é de grande importância para produção satisfatória de batata-doce, mesmo em áreas com baixas infestações por Meloidogyne (CHARCHAR \& RITSCHEL, 2004).

Nesse sentido esse trabalho teve como objetivo caracterizar a resistência de 10 genótipos de batata-doce aos nematoides de galhas Meloidogyne incognita e Meloidogyne paranaensis. 


\section{MATERIAL E MÉTODOS}

\section{1 - Obtenção do material genético}

Os genótipos utilizados foram cedidos à Universidade Brasília pela Embrapa Hortaliças (CNPH), os quais são mantidos em um Banco de Germoplasma. O CNPH mantêm esses genótipos em campos isolados para garantir o vigor e a sanidade dos mesmos. Na tabela 1 são apresentados os 10 genótipos e suas respectivas denominações, sendo que alguns deles não são cultivares conhecidas e não possuem nome comum.

Tabela 1 - Genótipos do Banco de Germoplasma (BAG) de batata-doce da Embrapa Hortaliças. FAV/UnB, 2015.

\begin{tabular}{cc}
\hline Genótipos do BAG & Denominação cultivares/clones \\
\hline CNPH 3 & Princesa \\
CNPH 5 & Roxinha \\
CNPH 9 & Brazlândia Rosada \\
CNPH 31 & Georgia Improved \\
CNPH 46 & Balão \\
CNPH 53 & - \\
CNPH 61 & Batata Africana 1 \\
CNPH 66 & Batata Correntina n ${ }^{\circ} 24$ \\
CNPH 80 & - \\
CNPH 1796 & Palmeira \\
\hline
\end{tabular}

\section{2 - Localização}

O ensaio foi instalado e conduzido em casa de vegetação, localizada na Estação Experimental de Biologia da Universidade de Brasília (UnB), situada em Brasília (DF) a cerca de $5 \mathrm{~km}$ da universidade. Possui uma área de aproximadamente 8 ha e está a $1.100 \mathrm{~m}$ de altitude, nas coordenadas $15^{\circ} 44^{\prime} 14 " \mathrm{~S}$ e 4752'52"W, próximo ao Lago Paranoá. O clima da região é caracterizado por duas estações típicas: verão chuvoso de outubro a abril e inverno seco de maio a setembro. O ensaio foi conduzido a partir do dia 23/01/15 a 18/05/15 havendo uma precipitação média de $195,67 \mathrm{~mm}$, temperatura média $21,2{ }^{\circ} \mathrm{C}$ e umidade relativa do ar média de $80,13 \%$.

\section{3 - Obtenção, manutenção e preparo do inóculo}

As espécies de nematoides utilizadas como inóculos foram Meloidogyne incognita e Meloidogyne paranaensis, foram cedidos pelo Departamento de Fitopatologia da Faculdade 
de Ciências Biológicas e pela Faculdade de Agronomia e Medicina Veterinária, ambas pertencentes a UnB. Todas as espécies fornecidas já haviam sido previamente caracterizadas e purificadas.

As espécies foram multiplicadas e mantidas isoladamente em plantas de tomateiro (Solanum lycopersicum, cv. "Santa Cruz") em casa de vegetação por aproximadamente 150 dias (figura 1). Para obtenção das mudas de tomateiro foi feita a semeadura (densidade de 2 sementes/célula) em bandejas de poliestireno com 128 células piramidais invertidas (40ml/célula), contendo substrato artificial à base de vermiculita e casca de Pinus sp.

No transplantio das mudas foram utilizados vasos de plásticos devidamente esterilizados, com capacidade para 2 litros. O solo utilizado para plantio foi do tipo Latossolo Vermelho-Amarelo, sendo esse esterilizado em autoclave a $120^{\circ} \mathrm{C}$. Foram feitas adubações no plantio e em cobertura, sendo que no plantio foram utilizados 30 gramas de NPK (4-14-8) por vaso e para a cobertura semanal 100g de MAP/10L água. Foram feitas pulverizações com fungicidas $\left(\right.$ Score $^{\circledR}-50 \mathrm{ml} / 100 \mathrm{~L}$ de água, Folicur ${ }^{\circledR}-100 \mathrm{ml} / 100 \mathrm{~L}$ de água e Cabrio Top ${ }^{\circledR}$ $200 \mathrm{~g} / 100 \mathrm{~L}$ de água) e inseticidas (Evidence $^{\circledR}$ - $30 \mathrm{~g} / 100 \mathrm{~L}$ de água), para o controle de pragas.

O inóculo foi preparado a partir das raízes galhadas de tomate por meio da extração de ovos de acordo com o método de Hussey \& Barker (1973) modificado por Bonetti (1981). As raízes galhadas foram cortadas em pedaços de aproximadamente $0,5 \mathrm{~cm}$ de comprimento e em seguida trituradas no liquidificador por 20 segundos com solução de hipoclorito de sódio ( $\mathrm{NaClO})$ a $5 \%$ (50 ml/ L de água). Em seguida foi vertida a suspensão em peneira com malha de 65 mesh sobre peneira de 500 mesh, sob água corrente abundante, evitando-se sempre o jato d'agua diretamente sobre o material. Os ovos que ficaram retidos na última peneira (500 mesh) foram colhidos em recipientes apropriados. Ao final foi feita a quantificação dos ovos em lupa estereoscópica, utilizando alíquotas de $1 \mathrm{ml}$ e contagem em triplicata. Obteve-se então o número médio de ovos contidos em $1 \mathrm{ml}$ e esse valor foi extrapolado para o volume total de solução. A suspensão obtida com os ovos e $\mathbf{J} 2$ foi utilizada para inocular as plantas de tomateiro. 


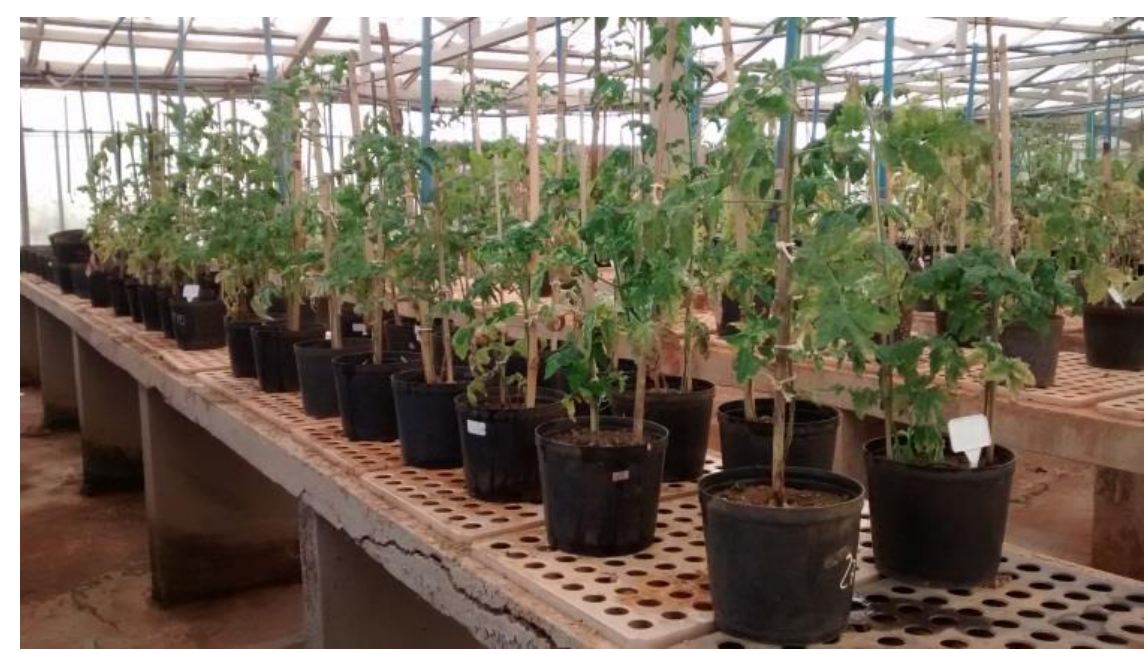

Fig. 1 - Multiplicação da espécie de nematoide $M$. incognita em mudas de tomateiro, em casa de vegetação, na Estação Experimental da Universidade de Brasília. UnB, Brasília, 2015. Foto: Daiane da S. Nóbrega.

\section{4 - Delineamento experimental}

Foram feitos dois ensaios, um para cada espécie de nematoide ( $M$. incognita e $M$. paranaensis). Ambos os ensaios foram instalados utilizando-se o delineamento experimental de blocos casualizados em arranjo simples, com 10 tratamentos e 3 repetições. Foram utilizadas 5 plantas de batata-doce/parcela para o $M$. incognita e 3 plantas de batatadoce/parcela para o M. paranaensis. Cada planta foi representada por uma estaca (rama) com 3 a 4 gemas.

\section{5 - Instalação do experimento}

Os genótipos foram plantados em sacos de poliestireno para mudas com capacidade de 2 L cada, contendo solo do tipo Latossolo Vermelho-Amarelo. No plantio foi realizado o enterrio de estacas (ramas) de batata-doce com aproximadamente $20 \mathrm{~cm}$ de comprimento, contendo 3 a 4 gemas, ficando apenas 1 a 2 gemas enterradas no substrato. O plantio foi executado em 23/01/15, sendo feito de forma que a estaca ficasse levemente inclinada para o favorecimento da ação de hormônios de crescimento.

\section{6 - Inoculação}

A inoculação foi feita 21 dias após o plantio das estacas de batata-doce. A suspensão contendo o inóculo foi distribuída manualmente, com auxílio de uma seringa plástica, de forma uniforme no solo ao redor do colo das estacas. Foram utilizados 3.000 ovos por planta (10 $\mathrm{ml}$ de suspensão/planta). 


\section{7 - Condução do experimento}

Durante a condução dos dois ensaios com $M$. incognita e $M$. paranaensis foram feitas três irrigações diárias por aspersão automatizada e irrigações complementares manualmente.

\section{8 - Avaliações}

Aos 90 dias após a inoculação $(18 / 05 / 2015)$ as plantas foram retiradas dos sacos de poliestireno para a realização das análises, sendo avaliadas as seguintes características: peso da massa fresca da parte aérea, peso da massa seca da parte aérea, peso da massa fresca da raiz, número de massas de ovos, número de ovos, grau de resistência e fator de reprodução.

\section{a) Peso da massa fresca (MFPA) e massa seca da parte aérea (MSPA)}

Após a retirada das plantas dos sacos de muda, a parte aérea de todas as plantas da parcela, foi separada da raiz e submetida à pesagem em balança de precisão, obtendo-se a massa fresca da parte aérea em gramas. Após aferido o peso a parte aérea foi colocada em sacos de papel kraft e levados à estufa de ar forçado por 72 horas à temperatura de $65^{\circ} \mathrm{C}$. Após este período, foi realizada uma nova pesagem do material em balança de precisão, obtendo-se o valor médio da massa seca da parte aérea por parcela em gramas.

\section{b) Número de massas de ovos}

Foi realizada a coloração das massas de ovos, segundo a técnica de Taylor e Sasser (1978), por meio da utilização de Floxina B. As raízes foram coradas em solução aquosa de Floxina B (15 mg/ L de água), permanecendo nessa solução por 15-20 minutos. Este procedimento facilita a visualização das massas de ovos depositadas pelas fêmeas na superfície do sistema radicular. Após a coloração foi quantificado o número de massas de ovos, individualmente, em cada sistema radicular.

\section{c) Grau de resistência}

Os genótipos foram classificados quanto à reação aos nematoides, com base no número médio de massas de ovos por parcela, segundo o sistema proposto por Taylor \& Sasser (1978) (tabela 2). O número médio de massas de ovos foi obtido a partir da contagem, individual, em cada sistema radicular da parcela e calculada a média. 
Tabela 2. Classificação da resistência de acordo com o número médio de massas de ovos presentes em cada sistema radicular. FAV/UnB, 2015.

\begin{tabular}{cc}
\hline Massa de ovos/sistema radicular & Grau de resistência \\
\hline 0 a 1,9 & Resistente (R) \\
2,0 a 2,9 & Moderadamente resistente (MR) \\
3,0 a 3,9 & Moderadamente susceptível (MS) \\
4,0 a 5,0 & Susceptível (S) \\
\hline
\end{tabular}

Grau de resistência a nematoides segundo Taylor e Sasser (1978).

\section{d) Peso da massa fresca da raiz (MFR)}

Posteriormente à coloração das raízes em Floxina $\mathrm{B}$ e quantificação das massas de ovos, procedeu-se a secagem natural das raízes. As raízes de todas as plantas pertencentes a uma mesma parcela foram reunidas e pesadas com auxílio de uma balança de precisão, obtendo-se o valor médio da massa fresca das raízes por parcela em gramas.

\section{e) Número de ovos}

Todas as raízes pertencentes à mesma parcela foram reunidas após a contagem das massas de ovos e foi feita a extração dos ovos do sistema radicular dos genótipos avaliados, segundo o método de Hussey \& Barker (1973) modificado por Bonetti (1981). A solução com os ovos foi armazenada sob temperatura média de $5^{\circ} \mathrm{C}$. Na quantificação dos ovos foram retiradas três alíquotas, cada uma contendo $1 \mathrm{ml}$ de solução, e cada qual foi diluída em $20 \mathrm{ml}$ de água. Foi realizada a contagem em triplicata em cada alíquota, com o auxílio de uma lupa estereoscópica e calculada a média. Em seguida foi calculada a média das três alíquotas. Depois de calculado o número médio de ovos por $\mathrm{ml}$ de solução, foi multiplicado o valor encontrado pelo volume total de solução, estimando-se o número total de ovos presente na solução correspondente a cada parcela. Também foi estimado o número de ovos/planta e ovos/grama de raiz.

\section{f) Fator de reprodução (FR)}

O fator de reprodução foi calculado através da razão entre o número total de ovos contabilizados em cada parcela na avaliação final (população final) e o número de ovos inoculados (população inicial). Os genótipos que apresentaram fator de reprodução maior ou igual a 1,0 foram considerados bons hospedeiros de nematoides (suscetíveis). Quando este 
valor foi inferior a 1,0 o genótipo foi considerado um hospedeiro ruim (resistente) (OOSTENBRINK, 1966).

$$
\text { FR }=\frac{\text { População final }}{\text { População inicial }}
$$

\section{9 - Análise estatística}

As análises estatísticas realizadas para avaliação dos resultados foram baseadas em modelos estatísticos apropriados para o delineamento utilizado. As variáveis foram submetidas à análise de variância, com exceção do grau de resistência, utilizando-se o teste de F ao nível de 5\% probabilidade. As médias foram agrupadas pelo teste de Tukey, ao nível de $5 \%$ probabilidade, com o auxílio do software SISVAR (FERREIRA, 2000). 


\section{RESULTADOS E DISCUSSÃO}

\section{1 - Reação de genótipos de batata-doce à infecção por Meloidogyne incognita}

$\mathrm{Na}$ análise de resistência a Meloidogyne incognita foram observadas diferenças significativas entre os tratamentos para todas as características analisadas, exceto para a massa fresca da parte aérea (MFPA/PL), massa seca da parte aérea (MSPA/PL), número de ovos por plantas (OVOS/PL) e fator de reprodução (FR) baseado no teste de $\mathrm{F}$ a $5 \%$ de probabilidade (tabelas 3 e 4). As características massa fresca da raiz por planta (MFR/PL), número de massas de ovos por planta (MO/PL) e número de ovos por grama de raiz (OVOS/GRAIZ) foram significativas ao nível de $1 \%$ de probabilidade, enquanto o número de ovos por parcela (OVOS/PA) foi significativo a 5\% de probabilidade na análise de variância (tabelas 3 e 4).

A MFR/PL e OVOS/GRAIZ apresentaram variabilidade significativa entre as médias dos tratamentos, pelo teste de Tukey.

Tabela 3 - Médias das variáveis massa fresca da parte aérea por planta (MFPA/PL), massa seca da parte aérea por planta (MSPA/PL), massa fresca da raiz por planta (MFR/PL), número de ovos por parcela (OVOS/PA), número de ovos por planta (OVOS/PL) e número de ovos por grama de raiz (OVOS/GRAIZ) dos tratamentos avaliados quanto a resistência a Meloidogyne incognita. FAV/UnB, 2015.

\begin{tabular}{|c|c|c|c|c|c|c|}
\hline $\begin{array}{c}\text { Genótipos do } \\
\text { BAG }\end{array}$ & $\begin{array}{l}\text { MFPA/ } \\
\text { PL (g) }{ }^{\text {NS }}\end{array}$ & $\begin{array}{l}\text { MSPA/ } \\
\text { PL (g) }{ }^{N S}\end{array}$ & $\begin{array}{c}\text { MFR/ } \\
\text { PL (g)** }\end{array}$ & $\begin{array}{c}\text { OVOS/ } \\
\text { PA* }\end{array}$ & $\begin{array}{c}\text { OVOS/ } \\
\text { PL }^{\text {NS }}\end{array}$ & $\begin{array}{l}\text { OVOS/G } \\
\text { RAIZ*** }\end{array}$ \\
\hline Roxinha & $4,44 \mathrm{a}$ & $2,22 \mathrm{a}$ & 5,83 abcd & $50166,67 \mathrm{a}$ & $20105,56 \mathrm{a}$ & $58,69 \mathrm{ab}$ \\
\hline Georgia Improved & $6,33 \mathrm{a}$ & $4,33 \mathrm{a}$ & $1,92 \mathrm{a}$ & $21466,67 \mathrm{a}$ & $4876,67 \mathrm{a}$ & $52,25 \mathrm{ab}$ \\
\hline CNPH 80 & $6,67 \mathrm{a}$ & $1,00 \mathrm{a}$ & $10,67 \mathrm{~cd}$ & 9916,67 a & $1983,33 \mathrm{a}$ & $13,10 \mathrm{a}$ \\
\hline Palmeira & $7,17 \mathrm{a}$ & $1,75 \mathrm{a}$ & 8,42 bcd & 65216,67 a & $13720,00 \mathrm{a}$ & $40,60 \mathrm{ab}$ \\
\hline Batata Africana 1 & $8,00 \mathrm{a}$ & $2,00 \mathrm{a}$ & $4,67 \mathrm{abc}$ & $7816,67 \mathrm{a}$ & $1563,33 \mathrm{a}$ & $20,21 \mathrm{ab}$ \\
\hline Balão & 8,00 a & $2,17 \mathrm{a}$ & 5,22 abcd & $71166,67 \mathrm{a}$ & $20564,44 \mathrm{a}$ & $54,76 \mathrm{ab}$ \\
\hline Princesa & & & & 38383,33 a & $8435,00 \mathrm{a}$ & $61,55 \mathrm{ab}$ \\
\hline Batata Correntina $\mathrm{n}^{\circ} 24$ & $9,58 \mathrm{a}$ & $1,50 \mathrm{a}$ & $7,92 \mathrm{bcd}$ & 88083,33 a & 20183,33 a & $48,70 \mathrm{ab}$ \\
\hline Brazlândia Rosada & $12,92 \mathrm{a}$ & $2,61 \mathrm{a}$ & $12,64 \mathrm{~d}$ & $44566,67 \mathrm{a}$ & $9702,78 \mathrm{a}$ & $24,12 \mathrm{ab}$ \\
\hline CNPH 53 & $14,33 \mathrm{a}$ & $3,33 \mathrm{a}$ & $3,67 \mathrm{ab}$ & 93566,66 a & $18713,33 \mathrm{a}$ & $76,42 \mathrm{~b}$ \\
\hline Média & 2,84 & 1,44 & 2,40 & 199,55 & 97,36 & 45,04 \\
\hline $\mathrm{CV} \%$ & 21,56 & 34,01 & 19,24 & 39,58 & 42,86 & 36,69 \\
\hline
\end{tabular}

* Significativo a $5 \%$ pelo teste $\mathrm{F}$. ** Significativo a $1 \%$ pelo teste $\mathrm{F} .{ }^{\mathrm{NS}}$ Não-significativo a $5 \%$ pelo teste $\mathrm{F}$. Médias seguidas pela mesma letra minúscula nas colunas não diferem entre si pelo teste "Tukey”, em nível de $1 \%$ ou $5 \%$ de probabilidade.

Os genótipos apresentaram diferença significativa quanto à massa fresca da raiz (MFR/PL). O genótipo Brazlândia Rosada demonstrou a maior massa fresca de raiz com 12,64 g de raiz/planta, enquanto o genótipo Georgia Improved apresentou 1,92 g/planta. O genótipo CNPH 80 (10,67 g/planta) demonstrou o segundo melhor resultado, seguido pelos 
genótipos Palmeira (8,42 g/planta) e Batata Correntina $\mathrm{n}^{\mathrm{o}} 24$ (7,92 g/planta), todos diferindo entre si. Os demais genótipos apresentaram valores inferiores de massa de raiz (tabela 3).

Kalkmann (2011) conduziu um estudo em casa de vegetação na Estação Experimental de Biologia da Universidade de Brasília (DF), no qual avaliou a resistência de 25 genótipos de batata-doce as raças de nematoides do gênero $M$. incognita raças 1 e 4 constando que a massa fresca da raiz se demonstrou significativa a $5 \%$ de probabilidade. A espécie $M$. incognita raça 1 apresentou valores para a MFR que variaram de $1,15 \mathrm{~g}$ a 18,82 g e a espécie $M$. incognita raça 4 variou de $0,67 \mathrm{~g}$ a 5,14 g de massa de raiz.

Gonçalves Neto (2012), estudando a campo 39 genótipos de batata-doce em Ijaci (MG), verificou que a cultivar Brazlândia Rosada demonstrou 11,30 t/ha de MFR, enquanto que o genótipo UFLA 07-26 apresentou o menor valor com 3,00 t/ha de MFR.

Os dados acerca da MFR/PL das literaturas citadas compreendem intervalos de valores similares aos resultados observados no presente estudo.

A característica MFPA/PL não foi significativa demonstrando ampla variação entre as médias dos tratamentos, mas as mesmas não diferiram significativamente entre si, segundo teste de Tukey a 5\% de probabilidade. O genótipo mais vigoroso foi o CNPH 53 com 14,33 $\mathrm{g} /$ planta, enquanto Roxinha foi o menos vigoroso com 4,44 g de peso da massa fresca da parte aérea/planta. A característica MSPA/PL também não apresentou diferença estatística entre os genótipos. O genótipo Georgia Improved apresentou a maior massa com 4,33 g/planta e o genótipo CNPH 80 apresentou a menor massa seca com 1,00 g/planta (Tabela 3).

Kalkmann (2011) verificou em casa de vegetação em Brasília (DF) que as características massa fresca da parte aérea e massa seca da parte aérea foram significativas a $1 \%$ de probabilidade. O genótipo de batata-doce 1210 demonstrou uma MFPA de 14,30 g, similarmente ao genótipo CNPH 53 (14,33 g) analisado no presente estudo. O menor valor encontrado da MFPA foi de 8,44 g na cultivar Amarela, sendo maior que o demonstrado no presente estudo $(4,44 \mathrm{~g})$. A MSPA apresentou valores que variaram de 0,37 g a 5,74 g, correspondente aos genótipos Brazlândia Branca e 1206, respectivamente, sendo ambos valores menores que os observados no presente trabalho $(1,00 \mathrm{~g}$ a $14,33 \mathrm{~g})$.

Andrade Júnior et al. (2012) relataram em um estudo a campo, conduzido em diamantina (MG), que a cultivar Brazlândia Rosada apresentou 16,2 t/ha de produtividade de massa verde e 1,2 t/ha de massa seca. No presente estudo, conduzido em casa de vegetação, essa mesma cultivar demonstrou uma MFPA de 12,92 g/planta $\left(12,92 \mathrm{~g} / 0,4 \mathrm{~m}^{2}\right)$ e 2,61 $\mathrm{g} /$ planta $\left(2,61 \mathrm{~g} / 0,4 \mathrm{~m}^{2}\right)$ de MSPA. 
Com base na pesquisa a campo desenvolvida por Gonçalves Neto (2012) em Ijaci (MG) dos 39 genótipos de batata-doce estudados dois, UFLA 07-37 e UFLA 07-45, obtiveram baixos valores em relação às variáveis MFPA e MSPA, apresentando 6,30 t/ha e 1,45 t/ha; 3,20 t/ha e 0,57 t/ha, respectivamente. Esses valores mesmo baixos, ainda sim, são maiores que os encontrados nesse estudo.

O número de OVOS/PA demonstrou efeito significativo, porém suas médias não diferiram entre si, mas apresentaram grande amplitude entre as mesmas. O tratamento Batata Africana 1 demonstrou o menor número médio de ovos com o valor de 7.816,67 ovos/parcela, exibindo a maior tolerância ao $M$. incognita dentre os tratamentos avaliados. O maior número de ovos foi demonstrado pelo genótipo CNPH 53 com 93.566,66 ovos/parcela (tabela 3).

Foi verificado que não houve variabilidade entre as médias do número de OVOS/PL. O genótipo Batata Africana 1 demonstrou o melhor resultado com 1.563,33 ovos/planta, enquanto o genótipo Balão demonstrou 20.564,44 ovos/planta, sendo o mais suscetível entre os tratamentos (tabela 3 ).

As médias do número de OVOS/GRAIZ apresentaram variabilidade diferindo entre si e alcançando um valor máximo de 76,42 ovos correspondente ao tratamento CNPH 53, enquanto o CNPH 80 mostrou maior tolerância com 13,10 ovos/g de raiz (Tabela 3).

Pode-se inferir que os genótipos que demonstraram um número médio menor de massas de ovos não necessariamente apresentaram um número médio menor de ovos (tabelas 3 e 4), pois mesmo não havendo a presença de massas de ovos é possível que haja ovos aderidos no sistema radicular. Isso se deve ao fato de que a presença de nematoides habitando na rizosfera das plantas não garante que esses estejam se reproduzindo no local e que venham a efetivamente colocar os ovos em massas nas raízes das plantas. Podem ser encontrados ovos nas raízes secundárias das plantas sem que necessariamente existam massas de ovos aderidas a elas (KALKMANN, 2011). 
Tabela 4 - Médias do fator de reprodução (FR), grau de resistência segundo o fator de reprodução (GRFR), número de massa de ovos por planta (MO/PL) e grau de resistência segundo o número de massas de ovos (GRMO) dos tratamentos avaliados quanto à resistência a Meloidogyne incognita. FAV/UnB, 2015.

\begin{tabular}{ccccc}
\hline $\begin{array}{c}\text { Genótipos do } \\
\text { BAG }\end{array}$ & FR $^{\text {NS }}$ & GRFR & MO/PL** & GRMO \\
\hline Roxinha & $0,11 \mathrm{a}$ & $\mathrm{R}$ & $53,61 \mathrm{a}$ & $\mathrm{S}$ \\
Georgia Improved & $0,17 \mathrm{a}$ & $\mathrm{R}$ & $24,18 \mathrm{a}$ & $\mathrm{S}$ \\
CNPH 80 & $0,40 \mathrm{a}$ & $\mathrm{R}$ & $11,73 \mathrm{a}$ & $\mathrm{S}$ \\
Palmeira & $0,06 \mathrm{a}$ & $\mathrm{R}$ & $40,70 \mathrm{a}$ & $\mathrm{S}$ \\
Batata & $0,39 \mathrm{a}$ & $\mathrm{R}$ & $8,80 \mathrm{a}$ & $\mathrm{S}$ \\
Africana 1 & $0,07 \mathrm{a}$ & $\mathrm{R}$ & $62,89 \mathrm{a}$ & $\mathrm{S}$ \\
Balão & $0,09 \mathrm{a}$ & $\mathrm{R}$ & $53,22 \mathrm{a}$ & $\mathrm{S}$ \\
Princesa & $0,04 \mathrm{a}$ & $\mathrm{R}$ & $74,62 \mathrm{a}$ & $\mathrm{S}$ \\
Batata Correntina $\mathrm{n}^{\circ} 24$ & $0,60 \mathrm{a}$ & $\mathrm{R}$ & $26,02 \mathrm{a}$ & $\mathrm{S}$ \\
Brazlândia Rosada & $0,04 \mathrm{a}$ & $\mathrm{R}$ & $39,93 \mathrm{a}$ & $\mathrm{S}$ \\
CNPH 53 & 0,37 & - & 5,83 & - \\
\hline Média & 63,07 & - & 38,46 & - \\
\hline CV\% & $\mathrm{S} \%$ &
\end{tabular}

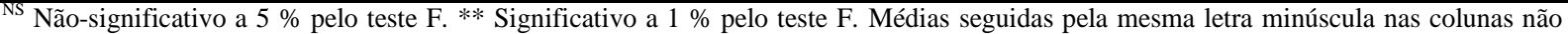
diferem entre si pelo teste "Tukey", em nível de $1 \%$ ou $5 \%$ de probabilidade.

O FR não apresentou significância e suas médias não diferiram entre si. O genótipo Brazlândia Rosada apresentou o maior FR $(0,60)$ do nematoide $M$. incognita, enquanto os genótipos Batata Correntina $\mathrm{n}^{\circ} 24(0,04)$ e CNPH $53(0,04)$ apresentaram os menores valores, sendo todos os genótipos resistentes ao microrganismo em questão (Tabela 4).

Gomes (2014), encontrou variabilidade para a resistência de 63 genótipos de batatadoce a Meloidogyne incognita raças 1 e 3 no município de Ijaci (MG). Observou que o FR foi significativo a $1 \%$ de probabilidade nas duas raças, sendo que a raça 1 variou entre 0,00 e 5,21; enquanto a raça 3 variou de 0,00 a 10,50. A raça 1 apresentou 49 genótipos resistentes e 14 genótipos suscetíveis, enquanto a raça 3 demonstrou 50 genótipos resistentes e 13 suscetíveis. Os valores do FR do presente estudo são similares aos valores observados por Gomes.

Wanderley e Santos (2004) conduziram um estudo na Universidade Estadual Paulista, Campus de Jaboticabal (UNESP) onde avaliaram a resistência de 35 cultivares de batata-doce a Meloidogyne incognita com base no fator de reprodução. Dentre as 35 cultivares avaliadas, 15 foram resistentes, as quais apresentaram fatores de reprodução desta espécie variando entre 0,05 (cv. Rama Fina) a 0,98 (cv. Roxa de Bonito). As demais cultivares apresentaram FR ao nematoide entre 1,16 e 21,34; sendo classificadas como suscetíveis. 
Os genótipos apresentaram diferenças significativas quanto ao número de massas de ovos (MO/PL), pelo teste de F, porém essas não diferiram entre si pelo teste de médias. A Batata Africana 1 com número médio de 8,80 massas de ovos por planta foi a mais tolerante, enquanto o Batata Correntina $n^{\circ} 24$ alcançou o maior número médio com 74,62 massas de ovos indicando maior suscetibilidade ao M. incognita (Tabela 4).

Baseado nos estudos de resistência a $M$. incognita raça 1 desenvolvidos por Kalkmann (2013) com 24 genótipos de batata-doce, em casa de vegetação, o número médio de massas de ovos mostrou variabilidade a $1 \%$ de probabilidade e variou entre 0,00 e 68,75 ; sendo 9 genótipos resistentes, 2 genótipos moderadamente resistentes e 13 genótipos suscetíveis. Esse intervalo de dados observado é próximo ao constatado no presente estudo.

Massaroto et al. (2010) estudando a reação de 50 genótipos de batata-doce a $M$. incognita raça 1, em casa de vegetação em Ijaci (MG), analisou a variável massas de ovos utilizando uma escala de notas diversa a deste estudo, adotada por Huang et al. (1986) e utilizada por Charchar \& Ritschel (2004). A cultivar Brazlândia Rosada recebeu uma nota média de massas de ovos de 2,73; correspondendo a um intervalo de 1 a 15 massas de ovos; classificando-se como moderadamente resistente. Esse mesmo autor, afirma que somente a cultivar Brazlândia Rosada demonstrou reação ao patógeno contrastante aos relatos citados na literatura. No presente estudo a mesma cultivar alcançou 26,02 MO/PL, sendo considerada suscetível segundo o GRMO, assim como relata a literatura.

Kalkmann (2011), também relata que as cultivares Brazlândia Branca e Brazlândia Roxa se mostraram suscetíveis segundo o grau de resistência baseado no número médio de massas de ovos.

Todos os genótipos se mostraram resistentes ao nematoide $M$. incognita, quanto ao GRFR, contudo, quanto ao GRMO os mesmos genótipos foram suscetíveis (tabela 4).

Em seu experimento sobre avaliação de resistência a $M$. incognita com batata-doce, Gomes (2014), observou o FR em 63 genótipos dos quais apenas 11 foram suscetíveis a raça 1 e somente 13 genótipos foram suscetíveis a raça 3, sendo a maioria classificada como resistente.

Kalkmann (2011), analisou a resistência de 24 genótipos de batata-doce a $M$. incognita raças 1 e 4 . A raça 1 apresentou 7 genótipos (Brazlândia Branca, Brazlândia Roxa, CNPH 1223, CNPH 1197, CNPH 1198, CNPH 1206, CNPH 1232) e a raça 4 demonstrou 2 genótipos (CNPH 1206 e CNPH 1232) com resultado semelhante ao presente estudo, sendo resistentes segundo o FR e suscetíveis baseado no número de MO/PL. 


\section{2 - Reação de genótipos de batata-doce à infecção por Meloidogyne paranaensis}

$\mathrm{Na}$ análise de resistência a Meloidogyne paranaensis foram observadas diferenças significativas entre os tratamentos para todas as características analisadas, exceto para o fator de reprodução, segundo o teste de $\mathrm{F}$ ao nível de $5 \%$ de probabilidade (tabelas 5 e 6 ). De acordo com o teste de Tukey as médias dos tratamentos diferiram para todas as variáveis observadas, havendo, de modo geral, uma grande amplitude entre as mesmas.

Tabela 5 - Médias das variáveis massa fresca da parte aérea por planta (MFPA/PL), massa seca da parte aérea por planta (MSPA/PL), massa fresca da raiz por planta (MFR/PL), número de ovos por parcela (OVOS/PA), número de ovos por planta (OVOS/PL) e número de ovos por grama de raiz (OVOS/GRAIZ) dos tratamentos avaliados quanto a resistência a Meloidogyne paranaensis. FAV/UnB, 2015.

\begin{tabular}{ccccccc}
\hline $\begin{array}{c}\text { Genótipos do } \\
\text { BAG }\end{array}$ & $\begin{array}{c}\text { MFPA/ } \\
\text { PL }(\mathbf{g}) * *\end{array}$ & $\begin{array}{c}\text { MSPA/ } \\
\text { PL }(\mathbf{g}) * *\end{array}$ & $\begin{array}{c}\text { MFR/ } \\
\text { PL }(\mathbf{g}) * *\end{array}$ & $\begin{array}{c}\text { OVOS/ } \\
\text { PA** }^{* *}\end{array}$ & $\begin{array}{c}\text { OVOS/ } \\
\text { PL** }\end{array}$ & $\begin{array}{c}\text { OVOS/G } \\
\text { RAIZ** }\end{array}$ \\
\hline Roxinha & $4,72 \mathrm{a}$ & $1,95 \mathrm{a}$ & $8,06 \mathrm{ab}$ & $3150,00 \mathrm{ab}$ & $1263,89 \mathrm{a}$ & $156,33 \mathrm{ab}$ \\
Georgia Improved & $4,44 \mathrm{a}$ & $1,67 \mathrm{a}$ & $2,00 \mathrm{a}$ & $20416,67 \mathrm{ab}$ & $6805,56 \mathrm{ab}$ & $4581,11 \mathrm{bc}$ \\
CNPH 80 & $5,00 \mathrm{a}$ & $1,67 \mathrm{a}$ & $8,89 \mathrm{ab}$ & $466,67 \mathrm{a}$ & $155,56 \mathrm{a}$ & $15,56 \mathrm{a}$ \\
Palmeira & $8,89 \mathrm{ab}$ & $1,67 \mathrm{a}$ & $9,45 \mathrm{ab}$ & $2916,67 \mathrm{a}$ & $972,22 \mathrm{a}$ & $99,94 \mathrm{ab}$ \\
Batata & $7,78 \mathrm{a}$ & $2,22 \mathrm{ab}$ & $6,11 \mathrm{ab}$ & $8050,00 \mathrm{ab}$ & $2683,33 \mathrm{a}$ & $406,39 \mathrm{ab}$ \\
Africana 1 & $8,89 \mathrm{ab}$ & $1,67 \mathrm{a}$ & $6,11 \mathrm{ab}$ & $158433,33 \mathrm{c}$ & $52811,11 \mathrm{c}$ & $12141,11 \mathrm{c}$ \\
Balão & $5,56 \mathrm{a}$ & $1,67 \mathrm{a}$ & $3,33 \mathrm{a}$ & $20416,67 \mathrm{ab}$ & $6805,56 \mathrm{ab}$ & $2162,22 \mathrm{ab}$ \\
Princesa & $5,56 \mathrm{a}$ & $1,67 \mathrm{a}$ & $15,00 \mathrm{~b}$ & $3266,67 \mathrm{a}$ & $1088,89 \mathrm{a}$ & $62,61 \mathrm{a}$ \\
Batata Correntina $\mathrm{n}^{\circ} 24$ & $15,28 \mathrm{ab}$ & $4,17 \mathrm{ab}$ & $16,11 \mathrm{~b}$ & $5366,67 \mathrm{ab}$ & $2508,33 \mathrm{ab}$ & $132,87 \mathrm{ab}$ \\
Brazlândia Rosada & $26,39 \mathrm{~b}$ & $5,83 \mathrm{~b}$ & $7,50 \mathrm{ab}$ & $48183,33 \mathrm{~b}$ & $17286,11 \mathrm{~b}$ & $2555,00 \mathrm{abc}$ \\
CNPH 53 & 2,85 & 1,49 & 2,73 & 116,98 & 68,94 & 31,58 \\
\hline Média & 25,94 & 21,06 & 22,49 & 46,81 & 44,71 & 59,18 \\
\hline CV \% & & & & &
\end{tabular}

O genótipo CNPH 53 foi o mais vigoroso com 26,39 g de MFPA/PL, enquanto a Georgia Improved apresentou a menor MFPA/PL com 4,44 g. Na sequência os genótipos Brazlândia Rosada (15,28 g), Palmeira (8,89 g) e Balão (8,89 g) atingiram os maiores valores sendo estatisticamente equivalentes, porém diferindo dos demais genótipos.

O genótipo CNPH 53 também se destacou quanto a MSPA/PL apresentando o maior valor com 5,83 g. O genótipo Brazlândia Rosada mostrou um bom resultado apresentando a segunda maior MSPA/PL com 4,17 g e em seguida o genótipo Batata Africana 1 com 2,22 g, ambos sendo estatisticamente iguais, porém diferem do genótipo CNPH 53.

O genótipo Brazlândia Rosada apresentou melhor desempenho de MFR/PL demonstrando 16,11 g e na sequência o genótipo Batata Correntina $\mathrm{n}^{\circ} 24$ com 15,00 g; sendo 
ambos estatisticamente idênticos. Os genótipos Georgia Improved (2,00 g) e Princesa (3,33 g) demonstraram as menores massas frescas de raiz diferindo de todos os demais tratamentos.

Kalkmann (2011) estudou a resistência de 25 genótipos de batata-doce aos nematoides M. incognita raças 1 e 4, em casa de vegetação, na Estação Experimental de Biologia da Universidade de Brasília (DF). As características MFPA, MSPA e MFR foram avaliadas para as duas raças. O M. incognita raça 1 apresentou variação de 8,44 g a 39,81 g; 0,37 g a 5,74 g; $1,15 \mathrm{~g}$ a 18,82 g; respectivamente; para essas características. O M. incognita raça 4 demonstrou 5,50 g a 31,75 g; 0,29 g a 4,81 g; 0,67 g a 5,14 g; respectivamente.

O número de OVOS/PA demonstrou grande amplitude entre os tratamentos variando de 466,67 a 158.433,33 ovos, correspondentes aos genótipos Balão e CNPH 80, respectivamente. Os genótipos Princesa (20.416,67), Georgia Improved (20.416,67), Batata africana 1 (8.050,00), Brazlândia Rosada $(5.366,67)$ e Roxinha $(3.150,00)$ apresentaram na sequência os melhores resultados, sendo estatisticamente semelhantes, porém diferindo dos demais genótipos.

Os resultados demonstrados pelo número de OVOS/PL e OVOS/GRAIZ estão relacionados com os observados para o número de OVOS/PA, pois os tratamentos apresentaram a mesma resposta, exceto os genótipos Batata Correntina $\mathrm{n}^{\mathbf{o}} 24$ e Palmeira para os OVOS/GRAIZ. O tratamento Balão apresentou o maior valor para as variáveis citadas, $52.811,11$ e $12.141,11$ respectivamente, sendo o mais suscetível ao M. paranaensis. O genótipo CNPH 80 apresentou os menores valores para as características em questão, 155,56 e 15,56 respectivamente, demonstrando ser o mais tolerante dentre os genótipos estudados.

Segundo Carmona (2015) em estudo de avaliação de resistência a $M$. javanica, $M$. incognita raça 1 e $M$. enterolobii com 44 genótipos de batata-doce, em casa de vegetação no Distrito Federal, observou 0,00 a 5.298,9; 0,00 a 5.304,3 e 0,00 a 40.226.2 ovos/grama de raiz, respectivamente para as espécies estudadas. 
Tabela 6 - Médias do fator de reprodução (FR), grau de resistência segundo o fator de reprodução (GRFR), número de massa de ovos por planta (MO/PL) e grau de resistência segundo o número de massas de ovos (GRMO) dos tratamentos avaliados quanto à resistência a Meloidogyne paranaensis. FAV/UnB, 2015.

\begin{tabular}{ccccc}
\hline $\begin{array}{c}\text { Genótipos do } \\
\text { BAG }\end{array}$ & FR $^{\text {NS }}$ & GRFR & MO/PL** & GRMO \\
\hline Roxinha & $1,02 \mathrm{a}$ & $\mathrm{S}$ & $5,22 \mathrm{ab}$ & $\mathrm{S}$ \\
Georgia Improved & $0,19 \mathrm{a}$ & $\mathrm{R}$ & $18,22 \mathrm{ab}$ & $\mathrm{S}$ \\
CNPH 80 & $0,71 \mathrm{a}$ & $\mathrm{R}$ & $1,67 \mathrm{a}$ & $\mathrm{R}$ \\
Palmeira & $3,43 \mathrm{a}$ & $\mathrm{S}$ & $11,56 \mathrm{ab}$ & $\mathrm{S}$ \\
Batata & $2,21 \mathrm{a}$ & $\mathrm{S}$ & $8,11 \mathrm{ab}$ & $\mathrm{S}$ \\
Africana 1 & $0,03 \mathrm{a}$ & $\mathrm{R}$ & $109,22 \mathrm{~d}$ & $\mathrm{~S}$ \\
Balão & $0,19 \mathrm{a}$ & $\mathrm{R}$ & $34,22 \mathrm{bc}$ & $\mathrm{S}$ \\
Princesa & $1,99 \mathrm{a}$ & $\mathrm{S}$ & $5,78 \mathrm{a}$ & $\mathrm{S}$ \\
Batata Correntina & $1,36 \mathrm{a}$ & $\mathrm{S}$ & $11,28 \mathrm{ab}$ & $\mathrm{S}$ \\
n 24 & $0,08 \mathrm{a}$ & $\mathrm{R}$ & $68,17 \mathrm{~cd}$ & $\mathrm{~S}$ \\
Brazlândia Rosada & 0,80 & - & 4,20 & - \\
CNPH 53 & 80,43 & - & 29,70 & - \\
\hline Média & $\mathrm{S}$ & & \\
\hline CV \% & & &
\end{tabular}

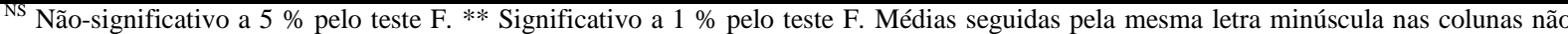
diferem entre si pelo teste "Tukey", em nível de $1 \%$ ou $5 \%$ de probabilidade.

Os genótipos não apresentaram diferenças significativas quanto ao FR. As médias variaram de 0,03 (Balão) a 3,43 (Palmeira) caracterizando como o genótipo mais tolerante e mais suscetível ao M. paranaensis, respectivamente. Cinquenta por cento dos genótipos foram classificados como resistentes e 50\% como suscetíveis segundo FR (tabela 6).

Carmona (2015) em estudando a resistência de 44 genótipos de batata-doce a $M$. javanica, $M$. incognita raça 1 e $M$. enterolobii em casa de vegetação em Brasília (DF), observou que o FR variou de 0,00 a 17,26; 0,00 a 11,02; 0,00 a 45,87, respectivamente, nas espécies estudadas. Quanto ao grau de resistência foram 39 genótipos resistentes (R) e 5 genótipos suscetíveis (S) a M. javanica, 23 genótipos (R) e 21 genótipos (S) a M. incognita raça 1 e 9 genótipos (R) e 35 genótipos (S) a M. enterolobii.

Gomes (2014), estudou a resistência de 63 genótipos de batata-doce a Meloidogyne javanica e Meloidogyne incognita raças 1 e 3 no município de Ijaci (MG). Observou que o FR do Meloidogyne javanica variou de 0,00 a 39,43; sendo 45 genótipos resistentes e 18 genótipos suscetíveis. Para o Meloidogyne incognita raças 1 e 3 observou-se que o FR da raça 1 variou entre 0,00 e 5,21; enquanto a raça 3 variou de 0,00 a 10,50. A raça 1 apresentou 49 genótipos resistentes e 14 genótipos suscetíveis, enquanto a raça 3 demonstrou 50 genótipos resistentes e 13 genótipos suscetíveis. Os valores para o FR observados no presente estudo são similares aos valores observados para Meloidogyne incognita raça 1. 
O número de MO/PL se mostrou significativo e apresentou grande variabilidade em suas médias. O genótipo Balão $(109,22)$ aparece como o mais suscetível, seguido dos genótipos CNPH $53(68,17)$ e Princesa $(34,22)$. O genótipo CNPH 80 (1,67) demonstrou o menor valor para essa característica. Todos os genótipos foram classificados como suscetíveis segundo o número de MO, exceto o genótipo CNPH 80 demonstrando resistência (tabela 6).

Carmona (2015), avaliando 44 genótipos de batata-doce quanto à resistência a $M$. javanica, $M$. incognita raça 1 e $M$. enterolobii em casa de vegetação no DF, observou valores de massas de ovos que variaram de 0,00 a 4,00; 0,00 a 3,67 e 0,00 a 4,83; respectivamente para as espécies estudadas, valores esses bem inferiores aos observados no presente estudo.

Cervantes-Flores et al. (2002) estudaram 26 genótipos de batata-doce quanto à resistência aos nematoides das galhas $M$. arenaria raças 1 e 2 e $M$. incognita raças 1, 2, 3 e 4 . O M. incognita raças 1, 2, 3 e 4 apresentou o número de massas de ovos por sistema radicular variando entre 0 e 85; 0 e 90; 0 e 50; 0 e 22; respectivamente. O $M$. arenaria raças 1 e 2 variou entre 0 e 3; 0 e 1,6; respectivamente.

Não há relatos na literatura a respeito da resistência da cultura de batata-doce a $M$. paranaensis, nem mesmo em culturas pertencentes à mesma família ou outras espécies tuberosas. Por outro lado, foram relatados alguns estudos a respeito da cultura do café (Coffea arabica L.) quanto à resistência a $M$. paranaensis.

Carneiro et al. (2008), analisaram a resistência de 2 progênies de Coffe arabica L. à M. paranaensis, no DF, apresentando para MFR 35,1 g na progênie H 419-5-4-5-2 e 16,1 g na progênie Catuaí Vermelho IAC 144, semelhante a cultivar Brazlândia Rosada (16,11 g) avaliada no presente trabalho. Boisseau et al. (2009), avaliaram na França 9 genótipos de cafeeiros quanto à resistência a uma população de $M$. paranaensis proveniente do Brasil, havendo uma variação da MFR de 4,7 g a 10,6 g e no presente estudo oscilou entre 2,00 g e 16,11 g. Também observaram 67,00 a 6.700,00 nematoides/planta (ovos + j2) e 8,00 a 1.013,00 nematoides/g de raiz, sendo que no presente estudo essas variáveis oscilaram de 155,56 a 52.811,11 ovos/planta e 15,56 a 12.141,11 ovos/g de raiz. O FR em 8 genótipos variou de 0,1 (R) a 0,6 (R) e apenas um genótipo apresentou valor bem superior de 8,9 (S), demonstrando os genótipos resistentes valores próximos aos observados no presente estudo.

Peres (2013), estudou 18 genótipos e 2 cultivares de $C$. arabica quanto a resistência a espécie $M$. paranaensis, em condições de campo e casa de vegetação em Brasília (DF). O peso médio de raízes frescas variou entre 34,08 g e 88,50 g, sendo esses dados superiores aos encontrados no presente estudo. Os ovos/g de raiz variaram de 14,00 a 569,00; enquanto no 
presente estudo oscilou de 15,56 a 12.141,11 ovos/g de raiz. O FR variou de 0,00 (Resistente) a 21,08 (Suscetível). Lima et al. (2013), estudando a resistência a Meloidogyne spp. em café, observou que os genótipos 14, 22 e Catuaí IAC 81 expressaram valores para MFR de 43,00 g; 38,40 g; 46,20 g; para $\mathrm{n}^{\mathrm{o}}$ de MO de 0,00; 4,71; 5,0 e para o FR 0,35 (R); 18,05 (S) e 32,50 (S); respectivamente. Os valores de MO observados para genótipo o 22 e Catuaí IAC 81 são próximos aos valores encontrados para os genótipos de batata-doce Roxinha $(5,22)$ e Batata Correntina $\mathrm{n}^{\mathrm{o}} 24(5,78)$ no presente estudo.

Sera et al. (2007), avaliou 63 progênies de cafeeiros à resistência ao M. paranaensis, em casa de vegetação, no Instituto Agronômico do Paraná em Londrina (PR). Utilizou uma escala de notas adaptada de 1 a 6, segundo Taylor (1971), para o número de galhas e/ou massas de ovos (GO), variando de 1,89 a 4,18; correspondente ao limite de até 100 GO. Dentre as 63 progênies foram $11(\mathrm{~S}), 29(\mathrm{MR})$ e $24(\mathrm{R})$. No presente trabalho o número de MO variou de 1,67 (CNPH 80) a 109,22 (Balão). Muniz et al. (2009), analisando a reação de 7 genótipos de $C$. arabica a $M$. paranaensis, em casa de vegetação no DF, observou 1.013,00 a 3.851,20 ovos/g de raiz, enquanto o presente estudo demonstrou 15,56 a 4.581,11 ovos/g de raiz. Observaram que todos os genótipos avaliados se mostraram suscetíveis com base no FR. 


\section{CONCLUSÕES}

No ensaio com Meloidogyne incognita o genótipo CNPH 53 apresentou a maior massa fresca da parte aérea, enquanto o genótipo Georgia Improved destacou-se em massa seca da parte aérea e o genótipo Brazlândia Rosada em massa fresca de raiz.

Os genótipos Batata Africana 1 e CNPH 80 mostraram os menores valores em número de OVOS/PA, número de OVOS/PL e número de MO/PL, enquanto CNPH 80 apresentou menor valor de número de OVOS/GRAIZ.

Todos os genótipos estudados demonstraram resistência ao $M$. incognita com base na análise do fator de reprodução; apresentando valores menores que 0,6; porém os mesmos genótipos demonstraram suscetibilidade ao $M$. incognita com base no número de massas de ovos.

No ensaio com Meloidogyne paranaensis o genótipo CNPH 53 foi o mais vigoroso com relação à massa fresca da parte aérea e massa seca da parte aérea. Os genótipos Brazlândia Rosada e Batata Correntina $\mathrm{n}^{\circ} 24$ se destacaram para a massa fresca de raiz.

O genótipo CNPH 80 apresentou resultados superiores em todas as variáveis (número de OVOS/PA, número de OVOS/PL, número de OVOS/GRAIZ e número de MO/PL) que envolviam contagem de ovos de Meloidogyne paranaensis, demonstrando-se o mais promissor.

O genótipo CNPH 80 apresentou resistência com base no número de massas de ovos, sendo os demais genótipos suscetíveis. Os genótipos CNPH 80, Georgia Improved, Balão, Princesa e CNPH 53 demonstraram resistência segundo o fator de resistência, enquanto os demais genótipos foram suscetíveis.

O genótipo CNPH 80 foi o único que demonstrou resistência ao M. paranaensis tanto em relação ao fator de resistência, quanto ao número de massas de ovos. 


\section{CONSIDERAÇÕES FINAIS}

Os genótipos CNPH 53, Brazlândia Rosada, Santa Sofia e CNPH 29 demonstraram maiores valores de produtividade total estimada, enquanto os genótipos Brazlândia Rosada e Santa Sofia apresentaram os maiores valores de produtividade comercial estimada.

Sessenta por cento dos genótipos apresentaram-se moderadamente resistentes aos insetos de solo, correspondentes a Georgia Improved, Balão, CNPH 53, Batata Africana 1, Batata Correntina $\mathrm{n}^{\circ} 24$ e CNPH 71.

Os valores de $\mathrm{h}_{\mathrm{a}}{ }^{2}$ foram relativamente altos, porém apenas a característica produtividade comercial estimada, umidade e amido apresentaram valores de herdabilidade maiores que $90 \%$ e razão $\mathrm{CVg} / \mathrm{CVe}$ maior que 1, indicando suficiente diversidade genética para seleção e obtenção de progresso genético mesmo com a utilização de métodos de seleção simples, como a seleção massal.

Todos os genótipos demonstraram-se resistentes ao nematoide das galhas Meloidogyne incognita com base no fator de reprodução, porém todos apresentaram suscetibilidade quanto ao número de massas de ovos.

Os genótipos Georgia Improved, CNPH 80, Balão, Princesa e CNPH 53 apresentaram resistência segundo o fator de reprodução ao nematoide das galhas Meloidogyne paranaensis e apenas o genótipo CNPH 80 demonstrou-se resistente com base no número de massas de ovos.

O genótipo CNPH 80 foi o único a demonstrar resistência ao M. paranaensis tanto com relação ao fator de reprodução quanto ao número de massas de ovos. 


\section{REFERÊNCIAS BIBLIOGRÁFICAS}

ANDRADE JÚNIOR, V. C; VIANA, D. J. S; PINTO N. A. V. D.; RIBEIRO K. G.; PEREIRA, R. C.; NEIVA, I. P.; AZEVEDO, A. M.; ANDRADE, P. C. R. Características produtivas e qualitativas de ramas e raízes de batata-doce. Horticultura Brasileira, v. 30, n. 4, p. 584-589, out - dez 2012.

BONETTI, S.I. Inter-relacionamento de micronutrientes com o parasitismo de Meloidogyne exigua em mudas de cafeeiro (Coffea arabica L.). Dissertação (Mestrado), Viçosa: Universidade Federal de Viçosa, Viçosa - MG. 74p., 1981.

BOUISSEAU, M.; ARIBI, J.; SOUZA, F. R. DE; CARNEIRO, R. M. D. G.; ANTHONY, F. Resistance to Meloidogyne paranaensis in wild Coffea arabica. Tropical Plant Pathology, v. 34, n. 1, Jan - Feb, 2009.

CARMONA, P. O. Caracterização morfoagronômica, físico-química e tolerância ao nematoide-das-galhas de genótipos de batata-doce avaliados no Distrito Federal. Tese (Doutorado em Agronomia), Faculdade de Agronomia e Medicina Veterinária - FAV, Universidade de Brasília - UnB, Brasília, 227 f. :il., 2015.

CARNEIRO, R. M. D. G.; MESQUITA, L. F. G. DE; GONÇALVES, W.; PEREIRA, A. A. Pathogenicity of Meloidogyne spp. (Tylenchida: Meloidogynidae) from Brazil and Central America on two genotypes of Coffea arabica.Tropical Plant Pathology, v. 33, n. 4, Jul -Ago, 2008.

CARNEIRO, R.M.D.G.; CARNEIRO, R.G.; ABRANTES, I.M.O.; et al. Meloidogyne paranaensis n.sp., a root-knot nematode parasitizing coffee in Brazil. Journal of Nematology. v.28, p.177-189, 1996.

CERVANTES-FLORES, J. C.; YENCHO, G. C.; DAVIS, E. L. Host reactions of sweetpotato genotypes to root-knot nematodes and variation in virulence of Meloidogyne incognita populations. HortScience, v. 37, n. 7, p. 1112-1116, 2002.

CHARCHAR, J.M.; RITSCHEL, P.S. Avaliação do banco de germoplasma de batata-doce da Embrapa hortaliças para resistência a Meloidogyne spp. Brasília: EMBRAPA-CNPH, (Boletim de Pesquisa e Desenvolvimento, 3). 28p., 2004.

FERREIRA, P. V. Coleção Melhoramento de Plantas. Métodos de Melhoramento. Maceió: EDUFAL, v. 5, il., 2006.

FERREIRA, D. F. Análises estatísticas por meio do SISVAR para Windows. Versão 4.0. In: Reunião anual da região brasileira da sociedade internacional de biometria. Programas e Resumos... São Carlos (SP): UFSCar, 235p., 2000.

GOMES, J. A. A. Resistência de clones de batata-doce a nematoides (meloidogyne spp.). Dissertação (Mestrado - Programa de pós-graduação em produção vegetal), Faculdade de Ciências Agrárias, Universidade Federal dos Vales do Jequitinhonha e Mucuri - UFVJM, Diamantina (MG), 2014. 
GONÇALVES NETO, A. C.; MALUF, W.R.; GOMES, L. A. A.; MACIEL, G. M.; FERREIRA, R. P. D.; CARVALHO, R. C. Correlação entre caracteres e estimação de parâmetros populacionais para batata-doce. Horticultura Brasileira. v. 30, n. 4, p. 713-719, out - dez. 2012.

HUANG, S.P.; MIRANDA, J.E.C.; MALUF, W.R. Resistance to root-knot nematodes in a Brazilian sweet potato collection. Fitopatologia Brasileira, Lavras, v.11, p.761-767, 1986.

HUSSEY, R.S.; BARKER, K.R. A comparison of methods of collecting inocula of Meloidogyne spp. including a new technique. Plant Disease Report, Washington, v.57, n.12, p.1025-1028, Dec. 1973.

KALKMANN, D. C. Produtividade, qualidade de raiz, resistência aos insetos de solo e aos nematoides de galhas, e estimativas de parâmetros genéticos em clones de batatadoce cultivados no Distrito Federal. Dissertação (Mestrado em Agronomia), Faculdade de Agronomia e Medicina Veterinária - FAV, Universidade de Brasília - UnB, Brasília, 144 p., 2011.

KALKMANN, D. C.; PEIXOTO, J. R.; NOBREGA, D. S. Reação de clones de batata-doce à Meloidogyne incognita raças 1 e 4 e estimativa de parâmetros genéticos. Horticultura Brasileira, v. 31, n. 2, p. 293-296, abr. - jun., 2013.

LIMA, E. A. DE; FURLANETTO, C.; SOUSA, M. G.; MENEZES, A. C. M.; SOUSA, F. R. DE; ALMEIDA, M. R. A.; SERGIO JÚNIOR, A.; FERRÃO, M. A.; CARNEIRO, R. M. D. G. Resistência múltipla e resposta de hipersensibilidade do cafeeiro 'Conilon 14' a Meloidogyne spp. VIII Simpósio de Pesquisa dos Cafés do Brasil, Salvador - BA, 25 a 28 de novembro de 2013.

MASSAROTO, J. A.; GOMES, L. A. A., MALUF, W. R.; SILVA, R. R.; GOMES, A. R. DO V. A. Reação de clones de batata-doce ao meloidogyne incognita raça 1. Revista de Ciências Agro-Ambientais, Alta Floresta, v.8, n.1, p.1- 8, 2010.

MOENS, M.; PERRY, R. N.; STARR, J. L. Root-knot nematodes. Chapter 1: Meloidogyne Species - a Diverse Group of Novel and Important Plant Parasites. CCAB International, 2009.

MUNIZ, M. F. S.; CAMPOS,V. P.; MOITA, A. W.; GONÇALVES, W.; ALMEIDA, M. R. A.; SOUSA, F. R. DE; CARNEIRO, R. M. D. G. Reaction of coffee genotypes to different populations of Meloidogyne spp.: detection of a naturally virulent M. exigua population. Tropical Plant Pathology, v. 34, n. 6, nov. - dec., 2009.

NAVES, R.L. Diagnose e manejo de doenças causadas por fitonematoides na cultura da videira. Circular Técnica 57. Bento Gonçalves, RS: Embrapa Uva e Vinho, Dezembro 2005.

OOSTENBRINK, M. Major characteristics of the relation between nematodes and plants. Mededelingen Van De landbouwhogeschool Te Wageningen, v.66, p.1-46, 1966.

PERES, A. C. J. Seleção de genótipos de coffea arabica L. com resistência a Meloidogyne spp. em condições de casa de vegetação e a campo. Dissertação de Mestrado - Faculdade de Agronomia e Medicina Veterinária - FAV, Universidade de Brasília - UnB, Brasília, 94 p.: il., 2013. 
SERA, G. H.; SERA, T.; ITO, D.S.; MATA, J. S. DA; DOI, D. S.; AZEVEDO, J.A. DE; RIBEIRO FILHO, C. Progênies de Coffea arabica cv IPR-100 resistentes ao nematoide Meloidogyne paranaensis. Bragantia, Campinas, v.66, n.1, p.43-49, 2007.

TAYLOR, A.L. \& SASSER, J.N. Biology, identification and control of root-knot nematodes (Meloidogyne species). Raleigh: North Carolina State University Graphics, $111 \mathrm{p} ., 1978$.

WANDERLEY, M. J.; SANTOS, J. M. Resistência de cultivares de batata-doce a Meloidogyne incognita. Fitopatologia Brasileira, v. 29, p. 437-440, 2004. 
ANEXOS

ANEXO A: TABELAS DE ANÁLISES DE VARIÂNCIA E PARÂMETROS GENÉTICOS

\title{
CAPÍTULO I - PRODUTIVIDADE E RESISTÊNCIA DE CLONES DE BATATA- DOCE AOS INSETOS DE SOLO
}

\section{ANÁLISE DE VARIÂNCIA}

\begin{abstract}
Variável analisada: PRODUTIVIDADE TOTAL ESTIMADA
Opção de transformação: Raiz quadrada - SQRT ( Y )

TABELA DE ANÁLISE DE VARIÂNCIA
\end{abstract}

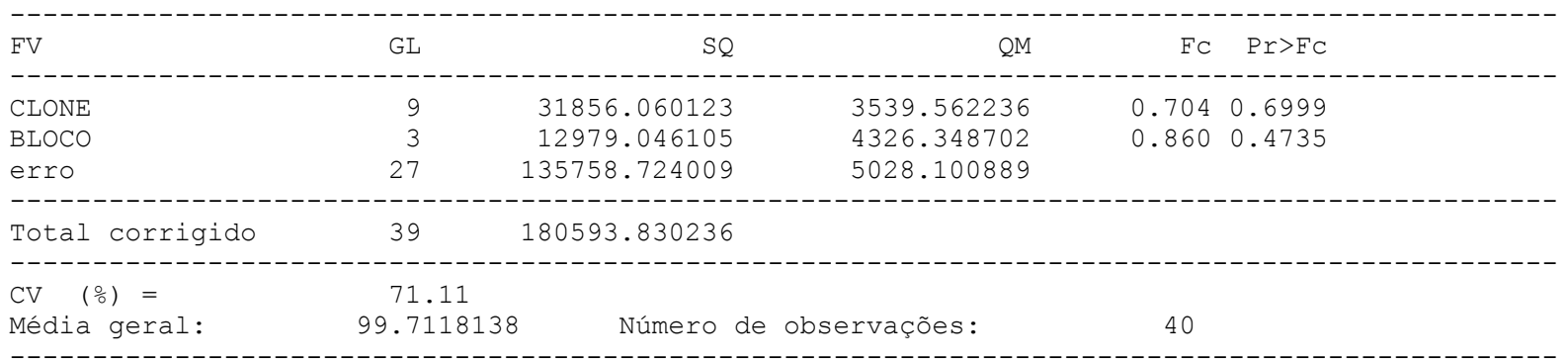

Variável analisada: PRODUTIVIDADE COMERCIAL ESTIMADA

opção de transformação: Variável sem transformação ( Y )

TABELA DE ANÁLISE DE VARIÂNCIA

$\begin{array}{lrrr} & \text { GL } & \text { SQ } & \text { QM }\end{array}$

Variável analisada: COMPRIMENTO

opção de transformação: Variável sem transformação ( Y )

TABELA DE ANÁLISE DE VARIÂNCIA

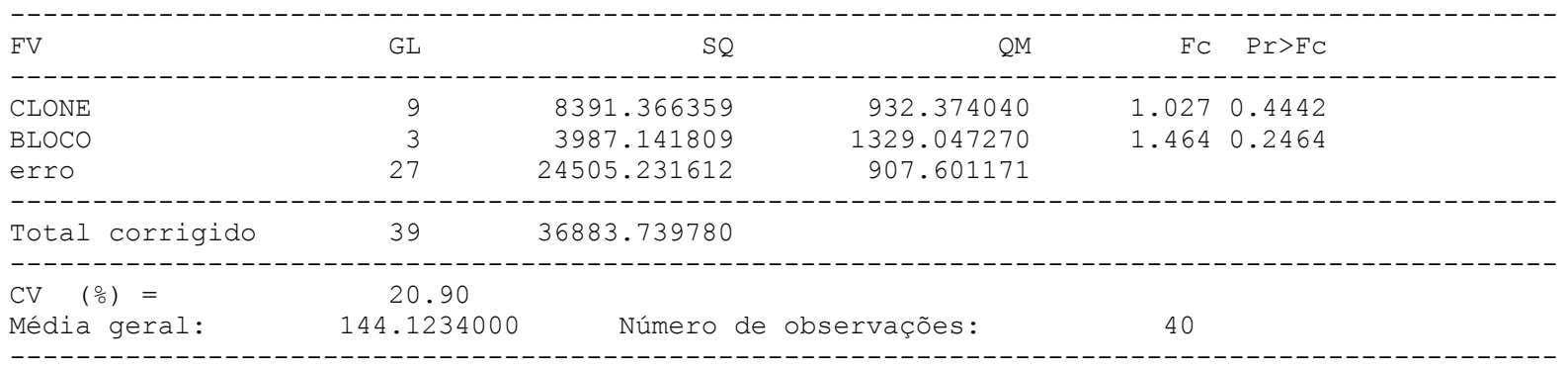


Variável analisada: ESPESSURA DA CASCA

opção de transformação: Variável sem transformação ( Y )

TABELA DE ANÁLISE DE VARIÂNCIA

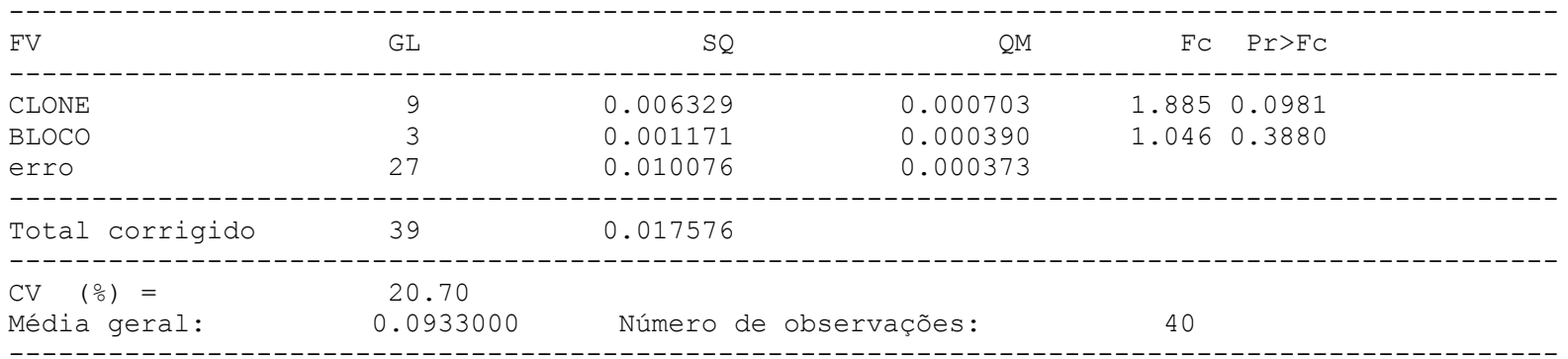

Variável analisada: NÚMERO DE FUROS

Opção de transformação: Raiz quadrada - SQRT ( Y )

TABELA DE ANÁLISE DE VARIÂNCIA

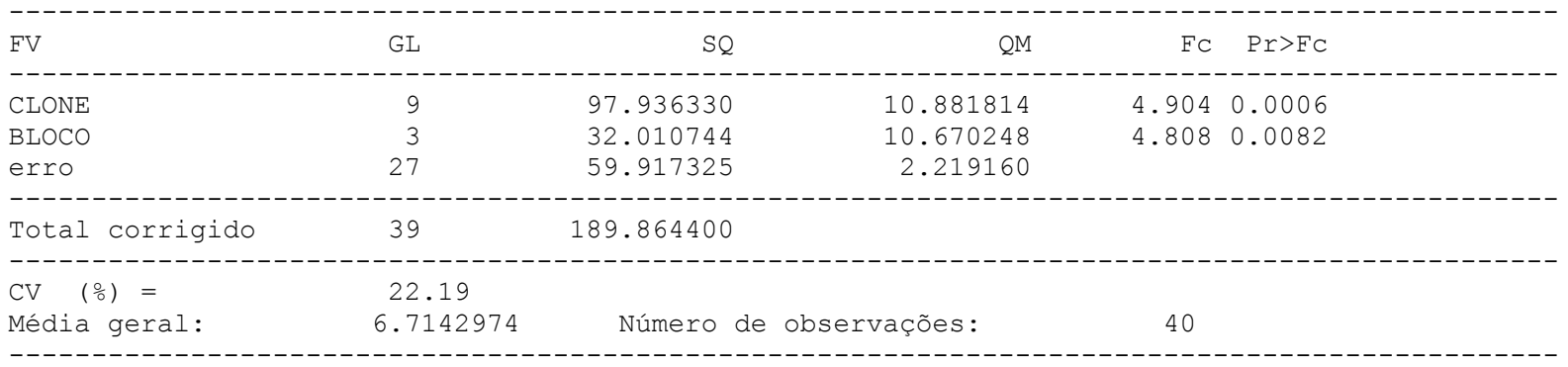

Variável analisada: ICIDÊNCIA DE DANOS

opção de transformação: Variável sem transformação ( Y )

TABELA DE ANÁLISE DE VARIÂNCIA

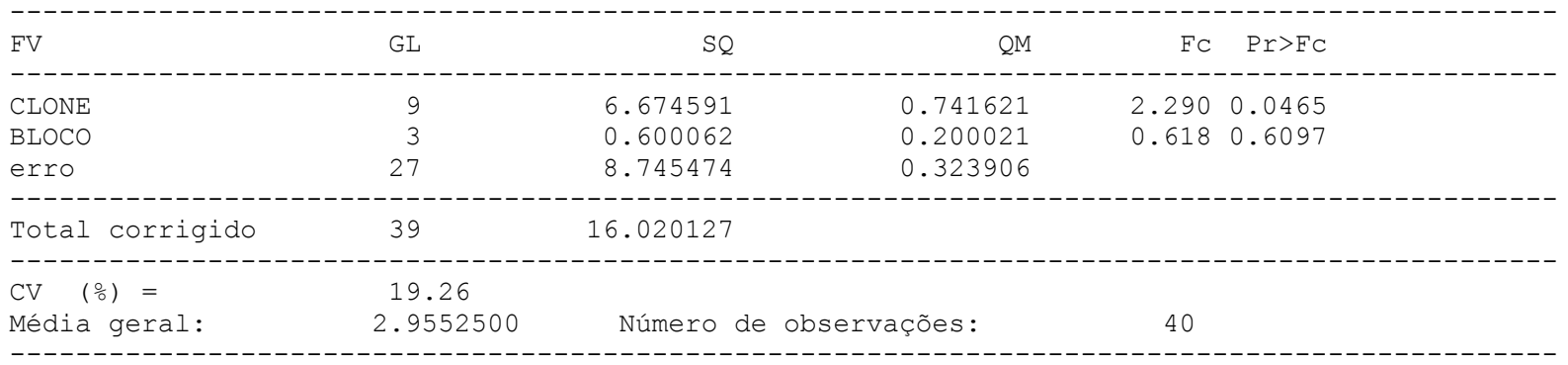

Variável analisada: FORMATO

opção de transformação: Variável sem transformação ( Y )

TABELA DE ANÁLISE DE VARIÂNCIA

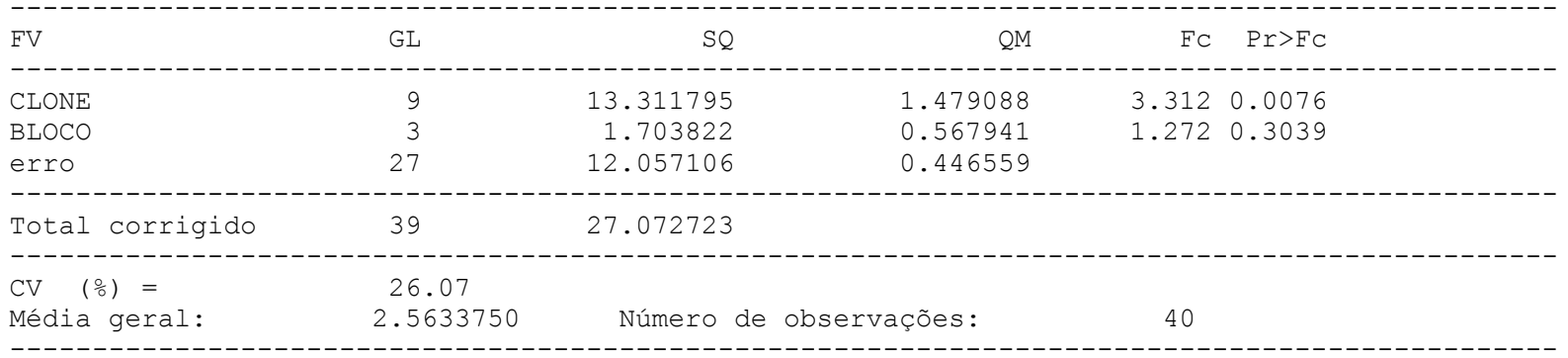


Variável analisada: UMIDADE

Opção de transformação: Variável sem transformação ( Y )

TABELA DE ANÁLISE DE VARIÂNCIA

\begin{tabular}{|c|c|c|c|c|}
\hline FV & GL & $\mathrm{SQ}$ & $\mathrm{QM}$ & $\mathrm{FC} \quad \mathrm{Pr}>\mathrm{FC}$ \\
\hline $\begin{array}{l}\text { CLONE } \\
\text { BLOCO } \\
\text { erro }\end{array}$ & $\begin{array}{r}9 \\
3 \\
27\end{array}$ & $\begin{array}{r}374.263651 \\
8.350325 \\
85.506043\end{array}$ & $\begin{array}{r}41.584850 \\
2.783442 \\
3.166890\end{array}$ & $\begin{array}{rr}13.131 & 0.0000 \\
0.879 & 0.4643\end{array}$ \\
\hline Total corrigido & 39 & 468.120019 & & \\
\hline $\begin{array}{l}\mathrm{CV} \quad(\%)= \\
\text { Média geral: }\end{array}$ & $\begin{array}{c}2.46 \\
72.4388500\end{array}$ & Número d & rações: & 40 \\
\hline
\end{tabular}

Variável analisada: AMIDO

opção de transformação: Variável sem transformação ( Y )

TABELA DE ANÁLISE DE VARIÂNCIA

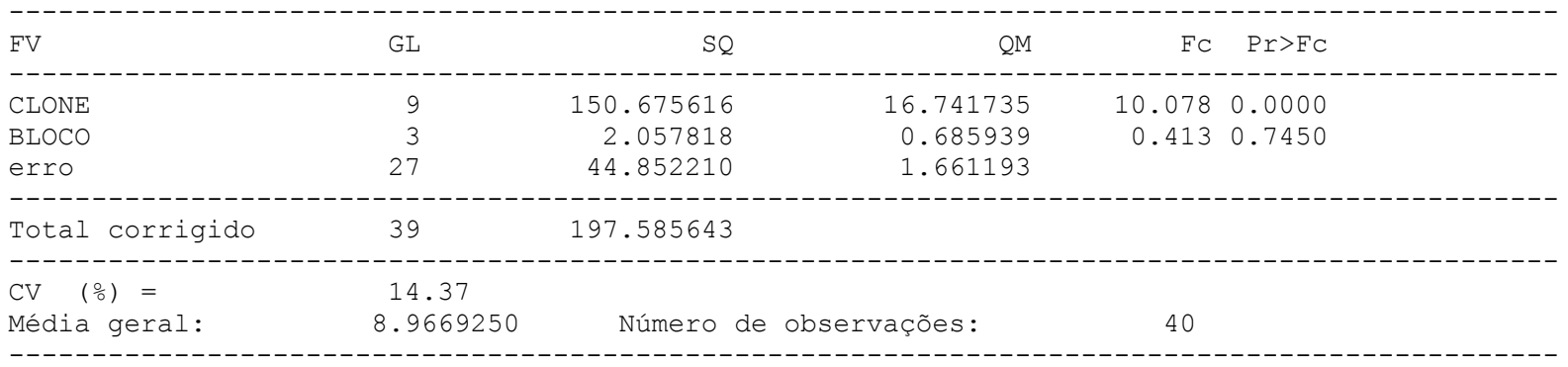

Variável analisada: ACIDEZ TOTAL TITULÁVEL

opção de transformação: Variável sem transformação ( Y )

TABELA DE ANÁLISE DE VARIÂNCIA

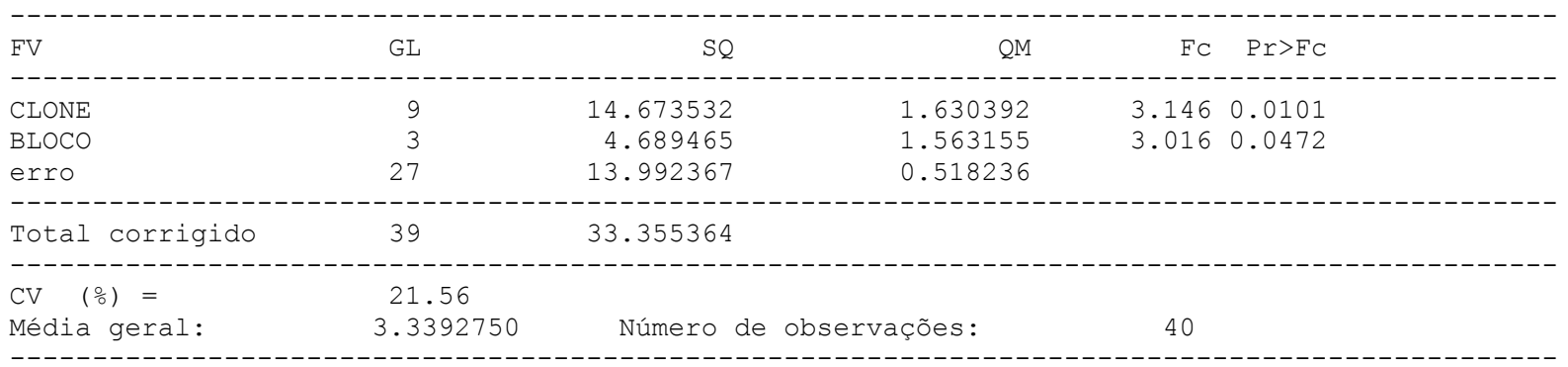

Variável analisada: SÓLIDOS SOLÚVEIS TOTAIS

opção de transformação: Variável sem transformação ( Y )

TABELA DE ANÁLISE DE VARIÂNCIA

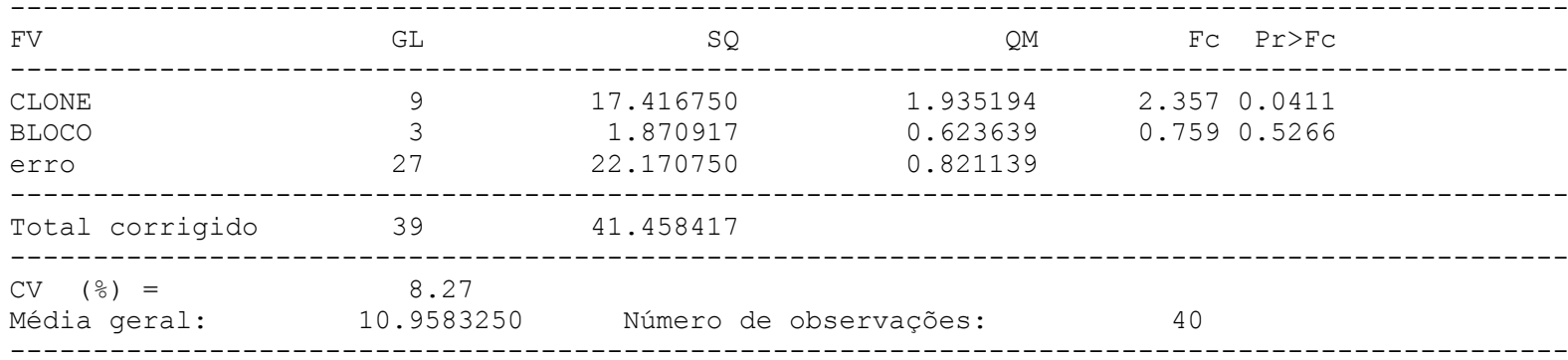


Variável analisada: RATIO (SST/ATT)

opção de transformação: Variável sem transformação ( Y )

TABELA DE ANÁLISE DE VARIÂNCIA

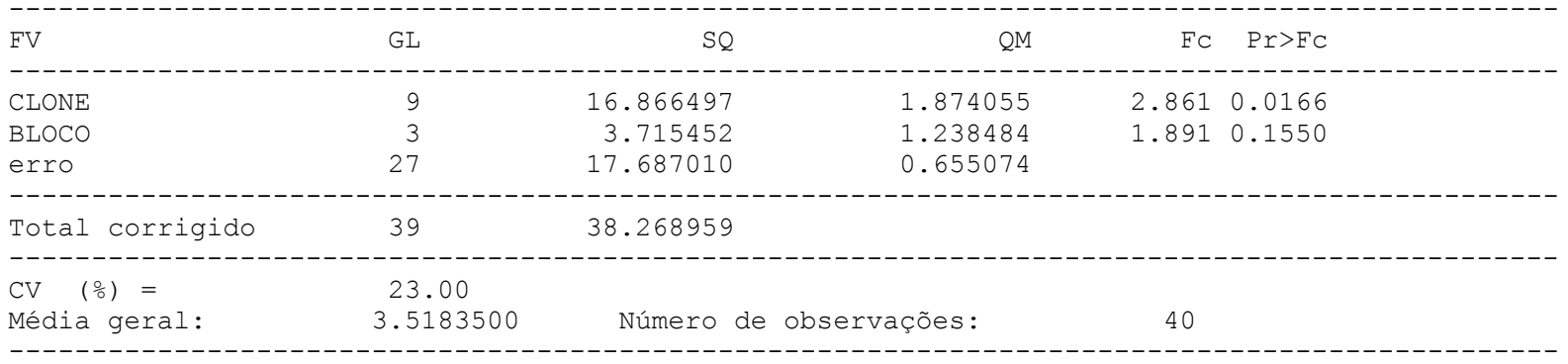

\section{PARÂMETROS GENÉTICOS}

Variável analisada: Produtividade comercial estimada

Estimates parameters

\begin{tabular}{ll}
\hline Phenotypic variance (means) & 261148770,662423 \\
Environmental variance (means) & 315210546,957177 \\
Genotypic variance (means) &, \\
Herdability (US: family means ) -\% &, \\
Correlation intraclass (US: plot) -\% &, \\
Coefficient of genetic variation (\%) &, \\
Relation CVg/CVe &
\end{tabular}

Variável analisada: Produtividade commercial estimada

Estimates parameters

\begin{tabular}{ll}
\hline Phenotypic variance (means) & 15513105,226467 \\
Environmental variance (means) & 1261780,800284 \\
Genotypic variance (means) & 14251324,426183 \\
Herdability (US: family means ) - $\%$ & 91,8664 \\
Correlation intraclass (US: plot) -\% & 73,847 \\
Coefficient of genetic variation (\%) & 64,8723 \\
Relation CVg/CVe & 1,6804
\end{tabular}

Variável analisada: Comprimento

Estimates parameters

\begin{tabular}{ll}
\hline Phenotypic variance (means) & 233,095592 \\
Environmental variance (means) & 226,900293 \\
Genotypic variance (means) & 6,195299 \\
Herdability (US: family means ) - \% & 2,6578 \\
Correlation intraclass (US: plot)-\% &, 678 \\
Coefficient of genetic variation (\%) & 1,727 \\
Relation CVg/CVe &, 0826
\end{tabular}

Variável analisada: Espessura da casca

Estimates parameters

\begin{tabular}{ll}
\hline Phenotypic variance (means) &, 000173 \\
Environmental variance (means) &, 000095 \\
Genotypic variance (means) &, 000077 \\
Herdability (US: family means ) - \% & 44,8239 \\
Correlation intraclass (US: plot)-\% & 16,881 \\
Coefficient of genetic variation (\%) & 9,4901 \\
Relation CVg/CVe &, 4507
\end{tabular}


Estimates parameters

\begin{tabular}{ll}
\hline Phenotypic variance (means) & 425,726271 \\
Environmental variance (means) & 123,443829 \\
Genotypic variance (means) & 302,282442 \\
Herdability (US: family means ) - & 71,0039 \\
Correlation intraclass (US: plot) -\% & 37,9724 \\
Coefficient of genetic variation (\%) & 34,8919 \\
Relation CVg/CVe &, 7824
\end{tabular}

Variável analisada: Incidência de danos

Estimates parameters

\begin{tabular}{ll}
\hline Phenotypic variance (means) &, 185205 \\
Environmental variance (means) &, 080981 \\
Genotypic variance (means) &, 104225 \\
Herdability (US: family means ) - $\%$ & 56,2752 \\
Correlation intraclass (US: plot) -\% & 24,3432 \\
Coefficient of genetic variation (\%) & 10,9233 \\
Relation CVg/CVe &, 5672
\end{tabular}

Variável analisada: Formato

Estimates parameters

\begin{tabular}{ll}
\hline Phenotypic variance (means) &, 369371 \\
Environmental variance (means) &, 111692 \\
Genotypic variance (means) &, 257679 \\
Herdability (US: family means ) - & 69,7616 \\
Correlation intraclass (US: plot) -\% & 36,579 \\
Coefficient of genetic variation (\%) & 19,8038 \\
Relation CVg/CVe &, 7595
\end{tabular}

Variável analisada: Umidade

Estimates parameters

\begin{tabular}{lc}
\hline Phenotypic variance (means) & 10,398908 \\
Environmental variance (means) &, 791397 \\
Genotypic variance (means) & 9,60751 \\
Herdability (US: family means ) -\% & 92,3896 \\
Correlation intraclass (US: plot)-\% & 75,2168 \\
Coefficient of genetic variation (\%) & 4,2789 \\
Relation CVg/CVe & 1,7421 \\
\hline
\end{tabular}

Variável analisada: Amido

Estimates parameters

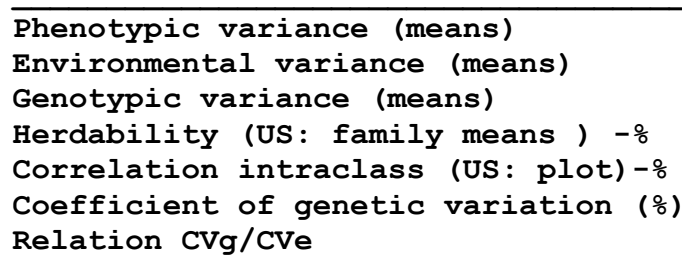


Variável analisada: Acidez Total Titulável

Estimates parameters

\begin{tabular}{ll}
\hline Phenotypic variance (means) &, 407891 \\
Environmental variance (means) &, 129219 \\
Genotypic variance (means) &, 278672 \\
Herdability (US: family means ) -\% & 68,3203 \\
Correlation intraclass (US: plot)-\% & 35,029 \\
Coefficient of genetic variation (\%) & 15,7993 \\
Relation CVg/CVe &, 7343 \\
\hline
\end{tabular}

Variável analisada: Sólidos Solúveis Totais

Estimates parameters

\begin{tabular}{ll}
\hline Phenotypic variance (means) &, 48382 \\
Environmental variance (means) &, 205278 \\
Genotypic variance (means) &, 278542 \\
Herdability (US: family means ) -\% & 57,5714 \\
Correlation intraclass (US: plot)-\% & 25,33 \\
Coefficient of genetic variation (\%) & 4,8162 \\
Relation CVg/CVe &, 5824 \\
\hline
\end{tabular}

Variável analisada: Ratio

Estimates parameters

\begin{tabular}{ll}
\hline Phenotypic variance (means) &, 468568 \\
Environmental variance (means) &, 164041 \\
Genotypic variance (means) &, 304527 \\
Herdability (US: family means ) -\% & 64,9911 \\
Correlation intraclass (US: plot) -\% & 31,6988 \\
Coefficient of genetic variation (\%) & 15,6851 \\
Relation CVg/CVe &, 6813 \\
\hline
\end{tabular}

\section{CAPÍTULO II - RESISTÊNCIA DE CLONES DE BATATA-DOCE AOS NEMATOIDES DE GALHAS DO GÊNERO Meloidogyne spp.}

\section{Meloidogyne incognita}

Variável analisada: MFPA/PL

Opção de transformação: Raiz quadrada - SQRT ( Y )

TABELA DE ANÁLISE DE VARIÂNCIA

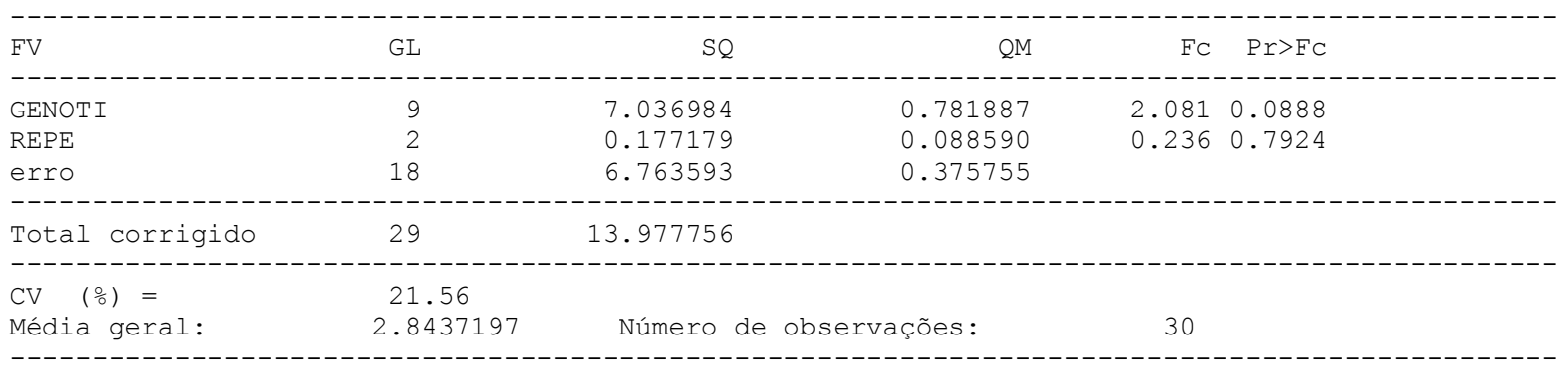


Variável analisada: MSPA/PL

Opção de transformação: Raiz quadrada - SQRT ( Y )

TABELA DE ANÁLISE DE VARIÂNCIA

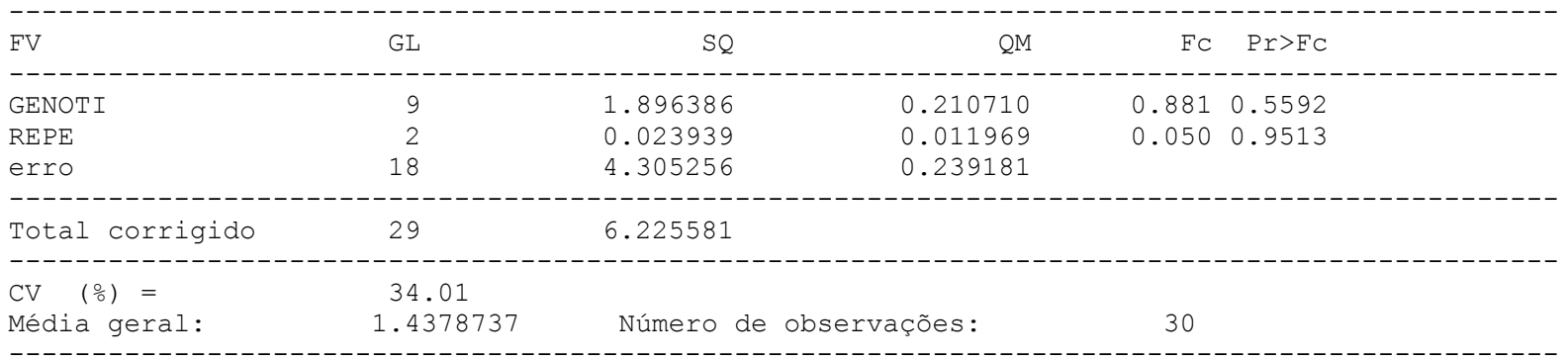

Variável analisada: MFR/PL

Opção de transformação: Raiz quadrada - SQRT ( Y )

TABELA DE ANÁLISE DE VARIÂNCIA

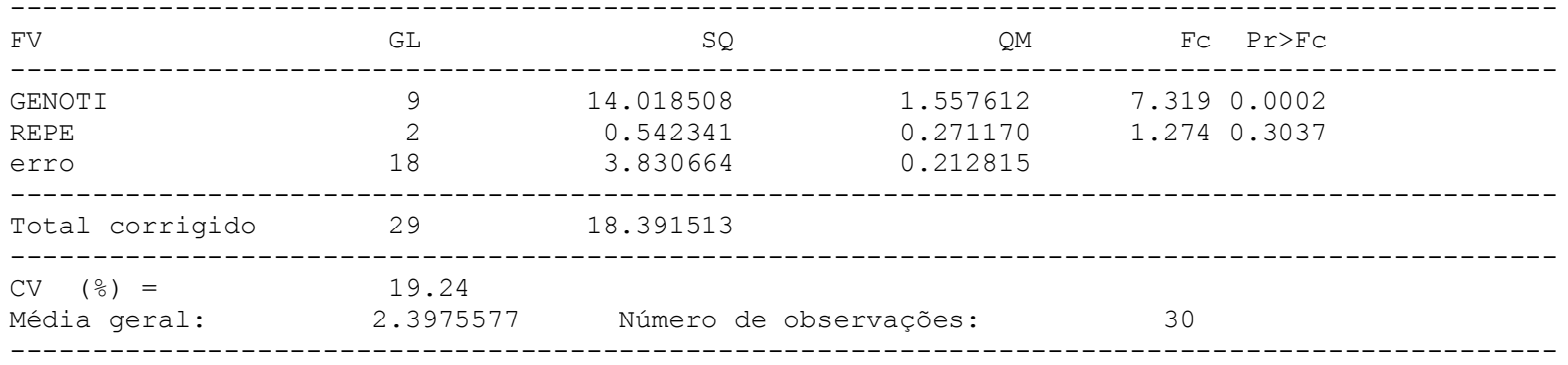

Variável analisada: $\mathrm{N}^{\circ}$ OVOS/PA

Opção de transformação: Raiz quadrada - SQRT ( Y )

TABELA DE ANÁLISE DE VARIÂNCIA

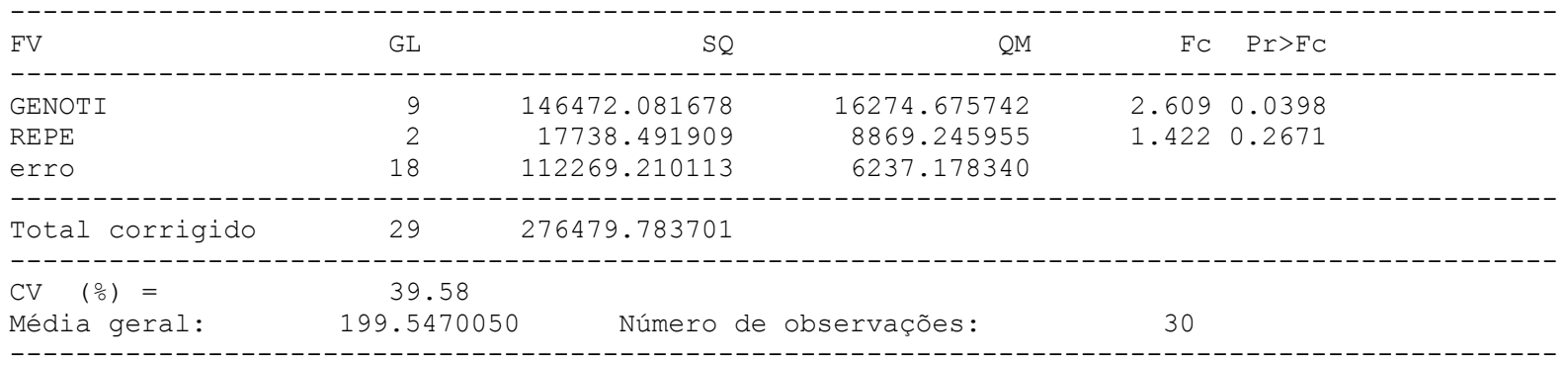

Variável analisada: OVOS/PL

Opção de transformação: Raiz quadrada - SQRT ( Y )

TABELA DE ANÁLISE DE VARIÂNCIA

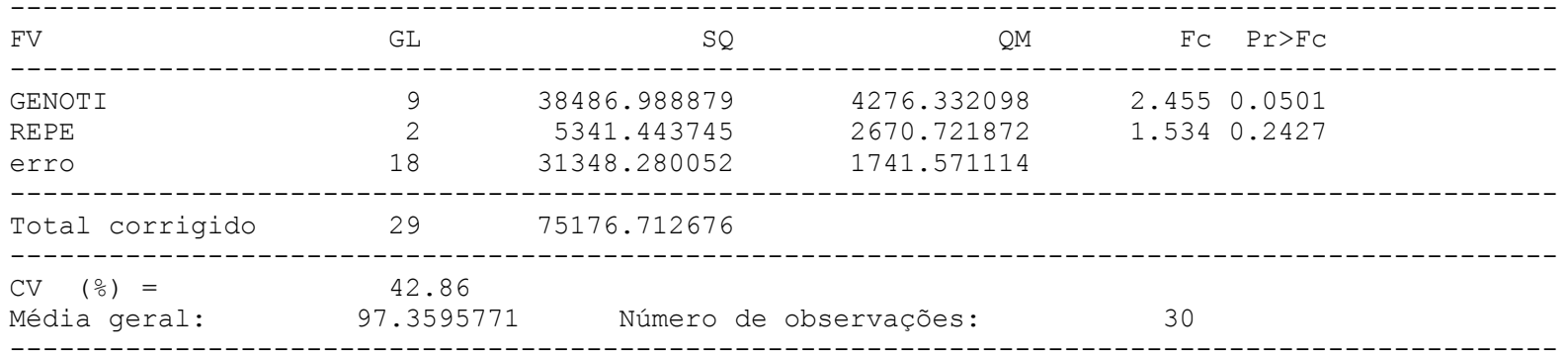


Variável analisada: OVOS/GRAIZ

Opção de transformação: Raiz quadrada - SQRT ( Y )

TABELA DE ANÁLISE DE VARIÂNCIA

\begin{tabular}{|c|c|c|c|c|}
\hline FV & GL & $\mathrm{SQ}$ & $\mathrm{QM}$ & $\mathrm{FC} \quad \mathrm{Pr}>\mathrm{FC}$ \\
\hline $\begin{array}{l}\text { GENOTI } \\
\text { REPE } \\
\text { erro }\end{array}$ & $\begin{array}{r}9 \\
2 \\
18\end{array}$ & $\begin{array}{r}11090.806312 \\
2896.938495 \\
4914.261507\end{array}$ & $\begin{array}{r}1232.311812 \\
1448.469248 \\
273.014528\end{array}$ & $\begin{array}{ll}4.514 & 0.0032 \\
5.305 & 0.0154\end{array}$ \\
\hline Total corrigido & 29 & 18902.006314 & & \\
\hline $\begin{array}{l}\mathrm{CV} \quad(\%)= \\
\text { Média geral: }\end{array}$ & $\begin{array}{c}36.69 \\
45.0392361\end{array}$ & Número d & ervações: & 30 \\
\hline
\end{tabular}

Variável analisada: $\mathrm{N}^{\circ} \mathrm{MO} / \mathrm{PL}$

Opção de transformação: Raiz quadrada - SQRT ( Y )

TABELA DE ANÁLISE DE VARIÂNCIA

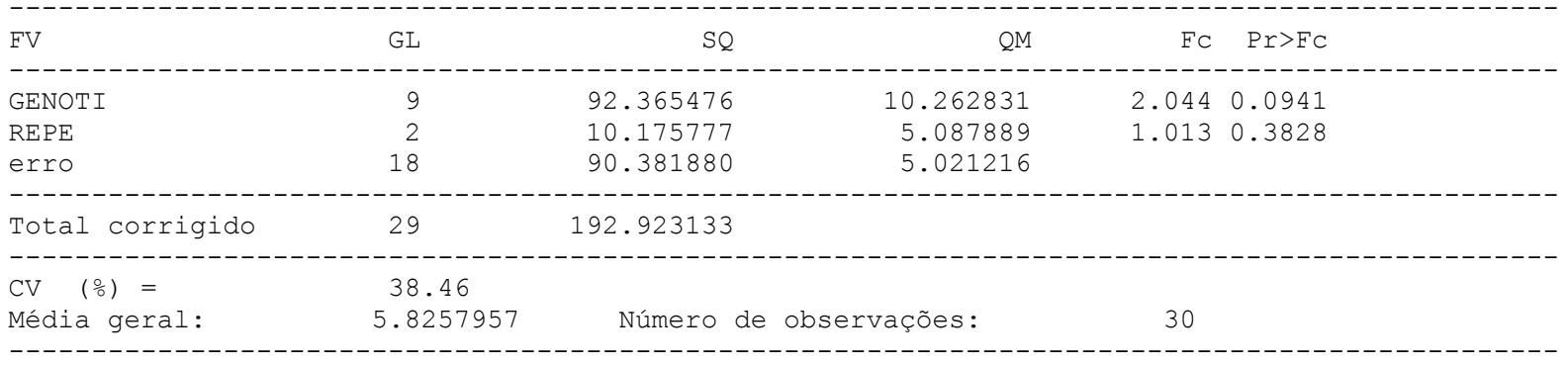

Variável analisada: FATOR DE REPRODUÇÃO

Opção de transformação: Raiz quadrada - SQRT ( Y )

TABELA DE ANÁLISE DE VARIÂNCIA

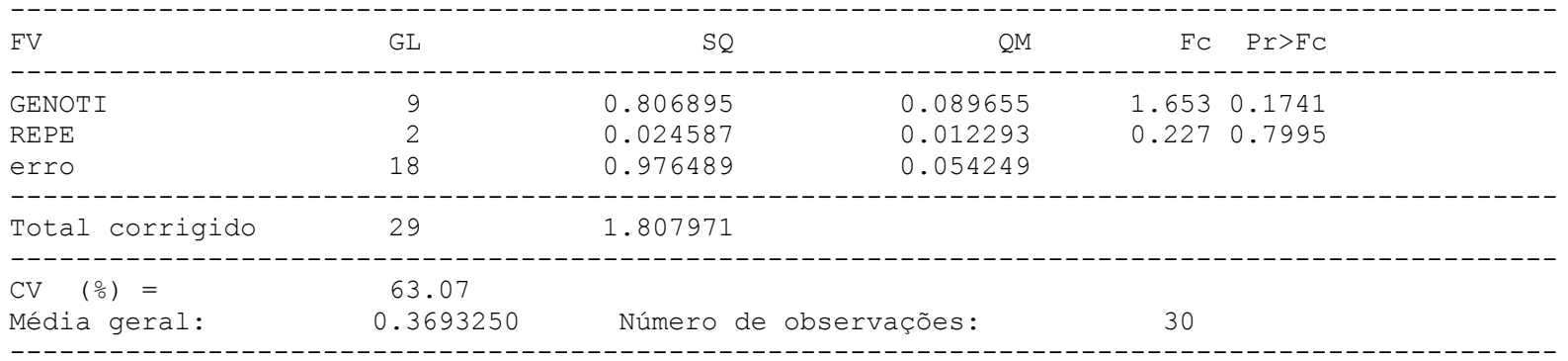

\section{Meloidogyne paranaensis}

Variável analisada: MFPA PL

Opção de transformação: $\bar{R} a i \bar{z}$ quadrada - SQRT ( Y )

TABELA DE ANÁLISE DE VARIÂNCIA

\begin{tabular}{|c|c|c|c|c|}
\hline FV & GL & $\mathrm{SQ}$ & $\mathrm{QM}$ & $\mathrm{FC} \quad \mathrm{Pr}>\mathrm{FC}$ \\
\hline GENOT & 9 & 23.098424 & 2.566492 & 4.7010 .0026 \\
\hline $\mathrm{REP}$ & 2 & 1.225380 & 0.612690 & 1.1220 .3473 \\
\hline erro & 18 & 9.826478 & 0.545915 & \\
\hline Total corrigido & 29 & 34.150281 & --- & -7 \\
\hline $\begin{array}{l}\mathrm{CV} \quad(\%)= \\
\text { Média geral: }\end{array}$ & $\begin{array}{l}25.94 \\
2.8481557\end{array}$ & Número d & ações: & 30 \\
\hline
\end{tabular}


Variável analisada: MSPA/PL

Opção de transformação: Raiz quadrada - SQRT ( Y )

TABELA DE ANÁLISE DE VARIÂNCIA

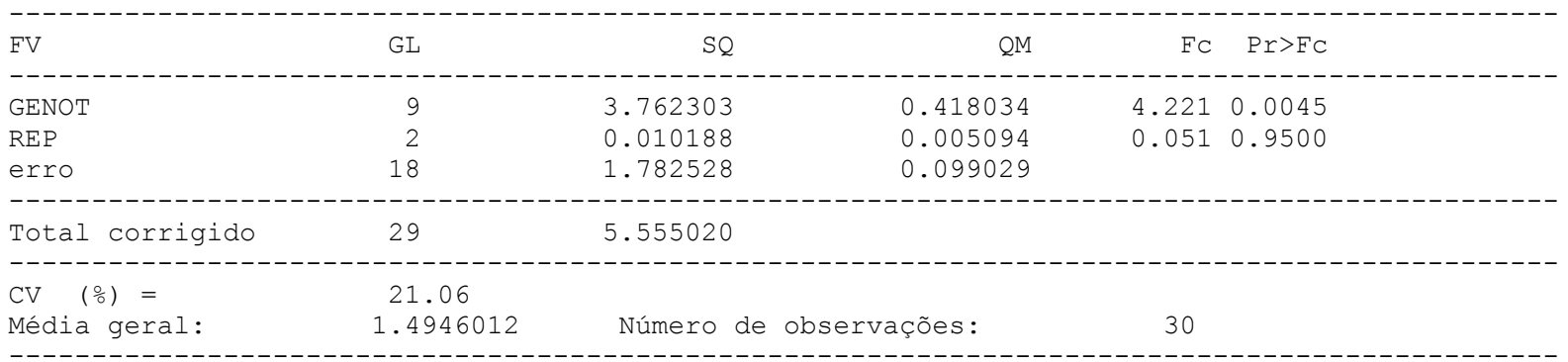

Variável analisada: MFR/PL

Opção de transformação: Raiz quadrada - SQRT ( Y )

TABELA DE ANÁLISE DE VARIÂNCIA

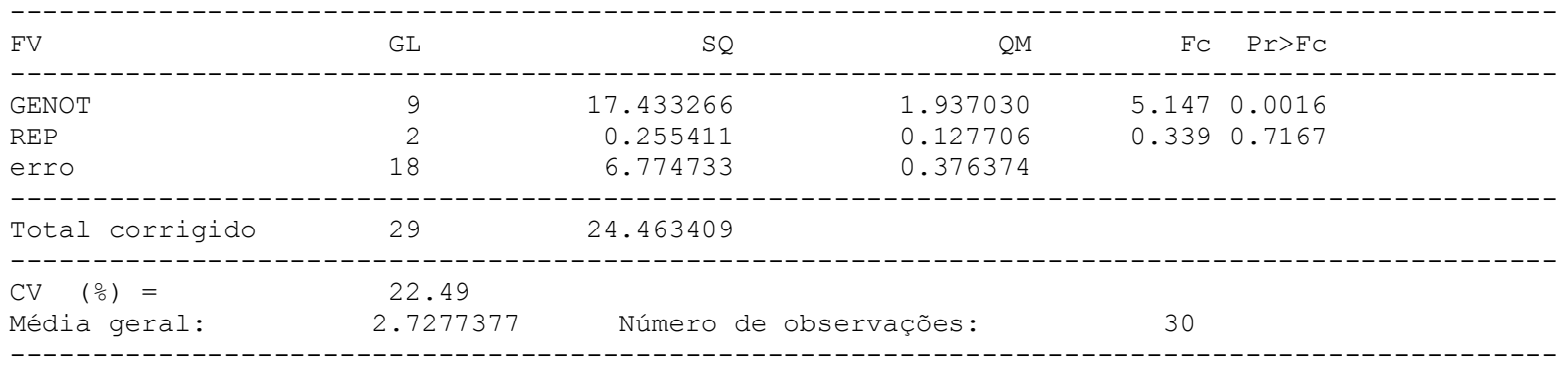

Variável analisada: $\mathrm{N}^{\circ}$ DE OVOS/PA

Opção de transformação: Raiz quadrada - SQRT ( Y )

TABELA DE ANÁLISE DE VARIÂNCIA

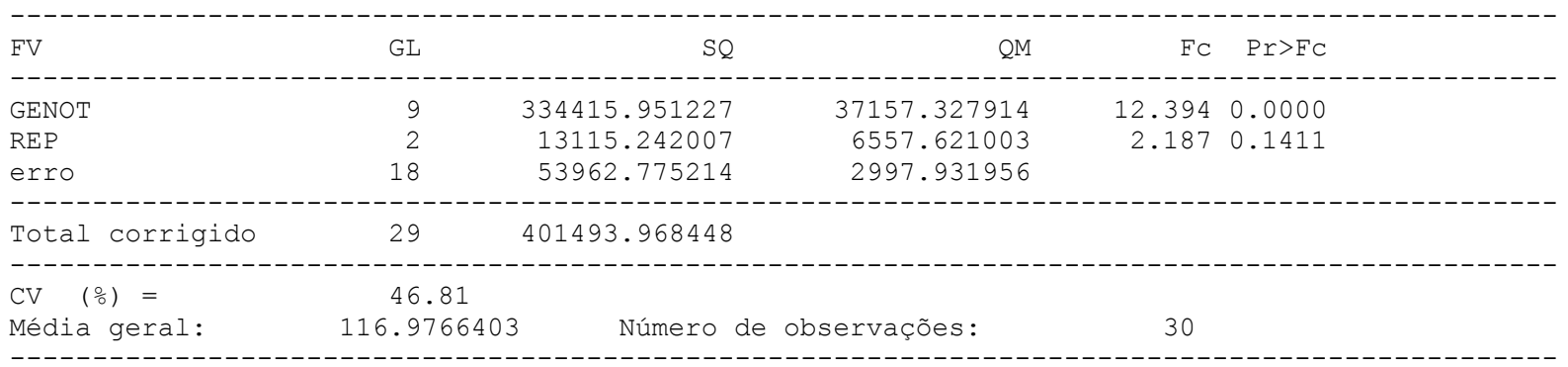

Variável analisada: OVOS/PL

Opção de transformação: Raiz quadrada - SQRT ( Y )

TABELA DE ANÁLISE DE VARIÂNCIA

\begin{tabular}{|c|c|c|c|c|}
\hline FV & GL & SQ & $\mathrm{QM}$ & $\mathrm{FC} \quad \mathrm{Pr}>\mathrm{FC}$ \\
\hline GENOT & 9 & 112332.756039 & 12481.417338 & 13.1360 .0000 \\
\hline REP & 2 & 5127.207136 & 2563.603568 & $2.698 \quad 0.0944$ \\
\hline erro & 18 & 17102.757444 & 950.153191 & \\
\hline Total corrigido & 29 & 134562.720619 & & \\
\hline $\mathrm{CV} \quad\left(\frac{\circ}{0}\right)=$ & 44.71 & -------------- & 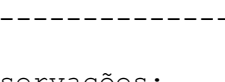 & 30 \\
\hline
\end{tabular}


Variável analisada: OVOS/GRAIZ

Opção de transformação: Raiz quadrada - SQRT ( Y )

TABELA DE ANÁLISE DE VARIÂNCIA

\begin{tabular}{|c|c|c|c|c|}
\hline FV & GL & $\mathrm{SQ}$ & $\mathrm{QM}$ & $\mathrm{FC} \quad \mathrm{Pr}>\mathrm{FC}$ \\
\hline GENOT & 9 & 28660.529656 & 3184.503295 & 9.1170 .0000 \\
\hline REP & 2 & 2075.237287 & 1037.618644 & 2.9710 .0768 \\
\hline erro & 18 & 6287.467148 & 349.303730 & \\
\hline--------------- & --------- & -------------- & ----------- & ------ \\
\hline Total corrigido & 29 & 37023.234091 & & \\
\hline $\begin{array}{l}\mathrm{CV}(\text { (\%) }= \\
\text { Média geral: }\end{array}$ & $\begin{array}{c}59.18 \\
31.5785824\end{array}$ & Número $\mathrm{d}$ & ervações: & 30 \\
\hline
\end{tabular}

Variável analisada: $\mathrm{N}^{\circ} \mathrm{MO} / \mathrm{PL}$

Opção de transformação: Raiz quadrada - SQRT ( Y )

TABELA DE ANÁLISE DE VARIÂNCIA

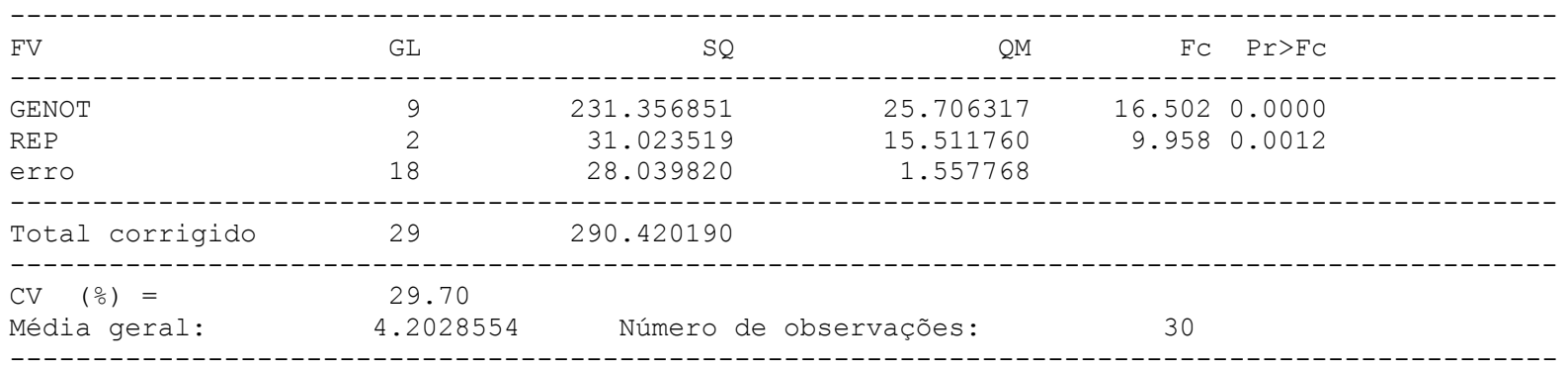

Variável analisada: FATOR DE REPRODUÇÃO

Opção de transformação: Raiz quadrada - SQRT ( Y )

TABELA DE ANÁLISE DE VARIÂNCIA

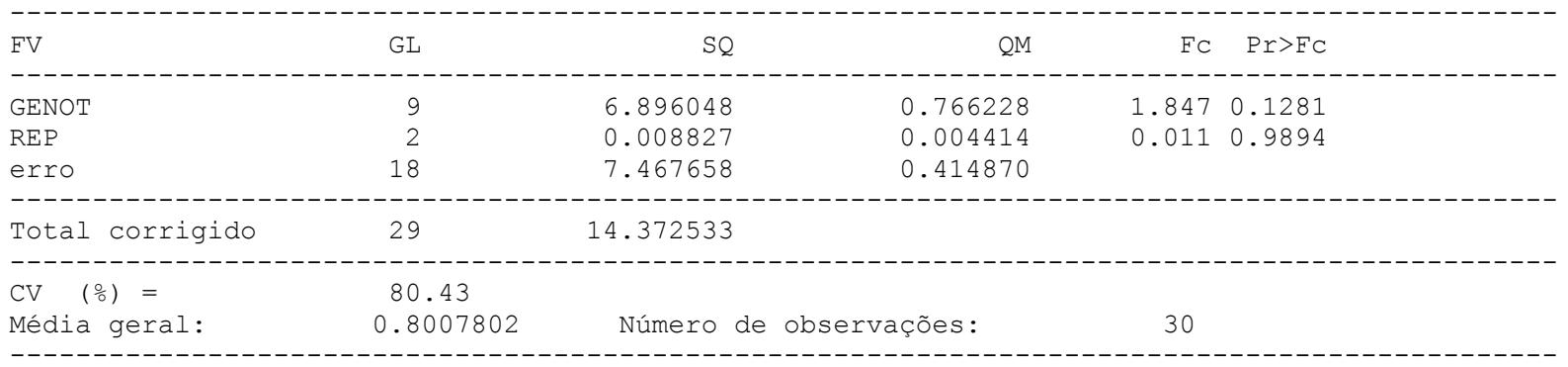


ANEXO B - CROQUI DA ÁREA EXPERIMENTAL EM CAMPO

\begin{tabular}{|c|c|c|c|c|}
\hline \multicolumn{5}{|c|}{ BLOCOS } \\
\hline & 1 & 2 & 3 & 4 \\
\hline \multirow{20}{*}{$\begin{array}{c}\mathbf{T} \\
\mathbf{R} \\
\mathbf{A} \\
\mathbf{T} \\
\mathbf{A} \\
\mathbf{M} \\
\mathbf{E} \\
\mathbf{N} \\
\mathbf{T} \\
\mathbf{O} \\
\mathbf{S}\end{array}$} & - & CNPH 17 & - & CNPH 31 \\
\hline & CNPH 31 & CNPH 46 & - & - \\
\hline & - & CNPH 29 & CNPH 9 & - \\
\hline & - & - & CNPH 66 & - \\
\hline & CNPH 61 & - & CNPH 3 & - \\
\hline & - & CNPH 3 & CNPH 17 & - \\
\hline & CNPH 71 & CNPH 9 & CNPH 29 & - \\
\hline & CNPH 53 & CNPH 66 & CNPH 46 & CNPH 61 \\
\hline & - & - & CNPH 31 & - \\
\hline & - & CNPH 31 & - & CNPH 53 \\
\hline & - & - & - & - \\
\hline & - & - & - & CNPH 66 \\
\hline & CNPH 17 & - & - & CNPH 9 \\
\hline & CNPH 46 & CNPH 61 & - & CNPH 17 \\
\hline & CNPH 29 & CNPH 71 & - & CNPH 71 \\
\hline & - & CNPH 53 & - & CNPH 3 \\
\hline & - & - & CNPH 61 & CNPH 46 \\
\hline & CNPH 66 & - & - & CNPH 29 \\
\hline & CNPH 9 & - & CNPH 53 & - \\
\hline & CNPH 3 & - & CNPH 71 & - \\
\hline
\end{tabular}


ANEXO C - FOTOS DOS ENSAIOS INOCULADOS EM CASA DE VEGETAÇÃO.

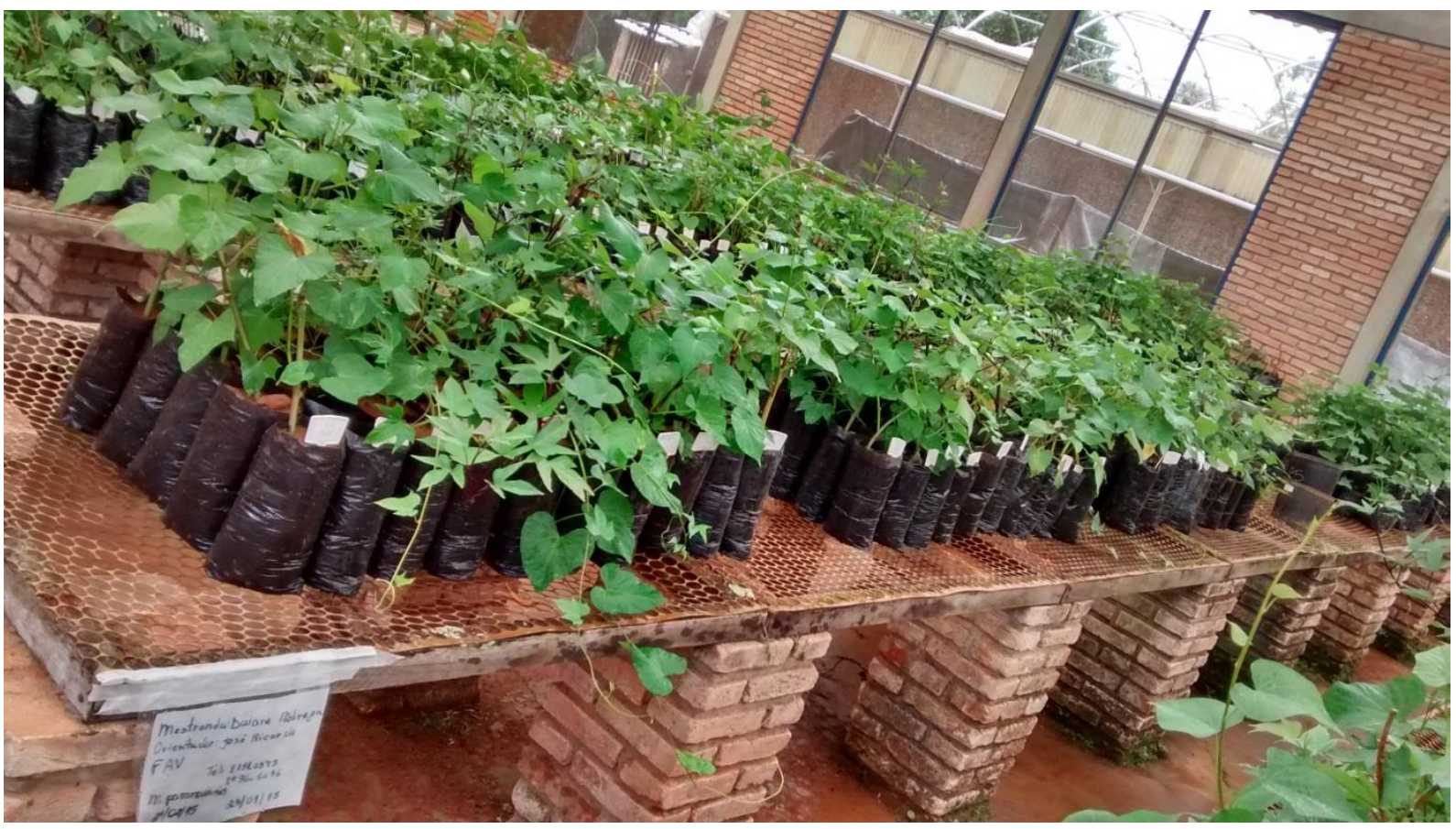

Meloidogyne paranaensis

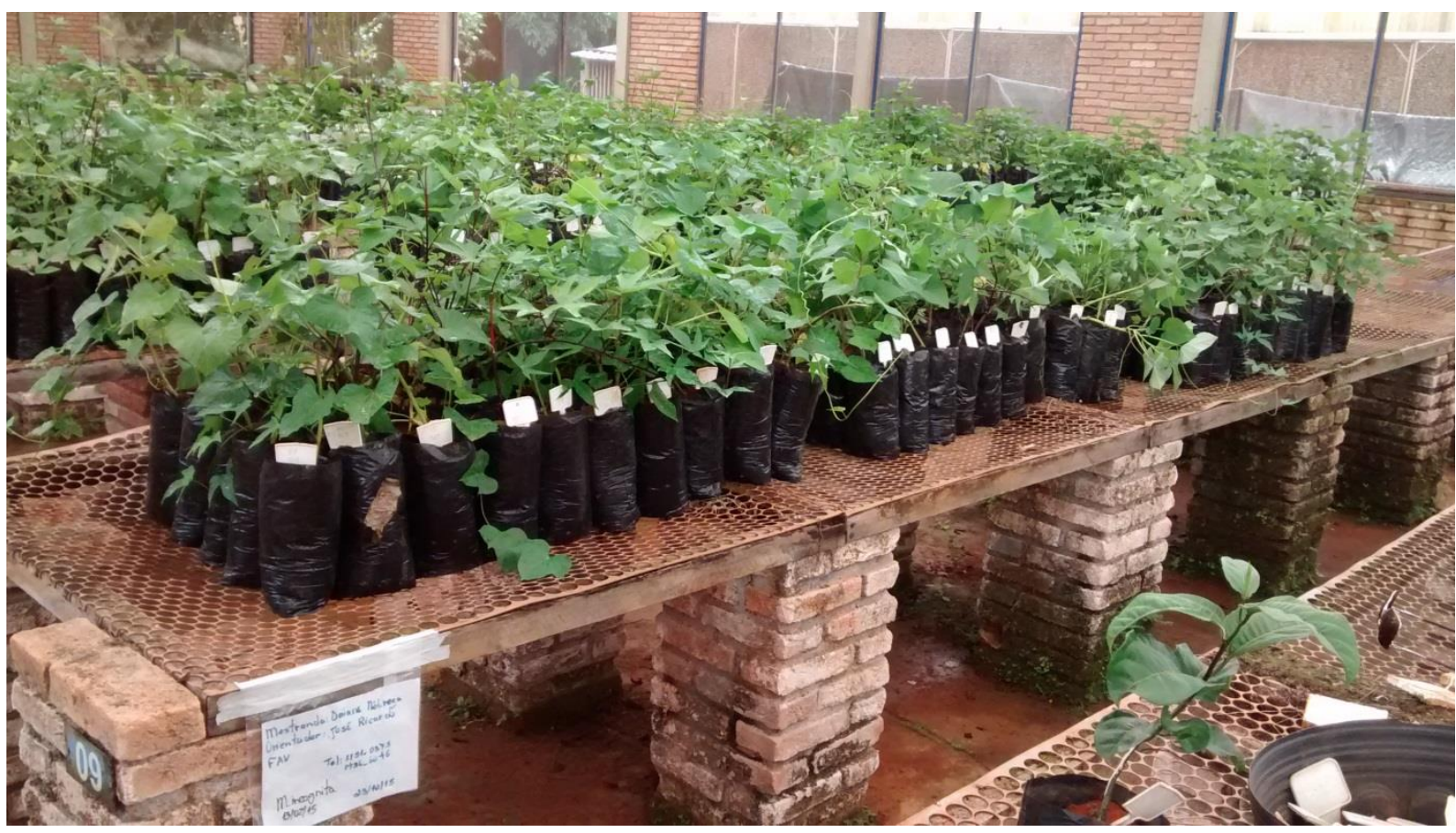

Meloidogyne incognita 